\title{
Proof-of-Concept Oil Shale Facility Environmental Analysis Program
}

\section{Topical Report}

November 1990

Work Performed Under Cooperative Agreement No.: DE-FC21-90MC27084

For

U.S. Department of Energy

Office of Fossil Energy

Morgantown Energy Technology Center

Morgantown, West Virginia

By

Occidental Oil Shale, Inc.

Steamboat Springs, Colorado

and

National Research Center for Coal and Energy

West Virginia University

Morgantown, West Virginia 


\section{DISCLAIMER}

This report was prepared as an account of work sponsored by an agency of the United States Government. Neither the United States Government nor any agency thereof, nor any of their employees makes any warranty, express or implied, or assumes any legal liability or responsibility for the accuracy, completeness or usefulness of any information, apparatus, product, or process disclosed, or represents that its use would not infringe privately owned rights. Reference herein to any specific commercial product, process, or service by trade name, trademark, manufacturer, or otherwise, does not necessarily constitute or imply its endorsement, recommendation, or favoring by the United States Govermment or any agency thereof. The views and opinions of authors expressed herein do not necessarily state or reflect those of the United States Government or any agency thereof.

This report has been reproduced directly from the best available copy.

Available to DOE and DOE contractors from the Office of Scientific and Technical Information, P.O. Box 62, Oak Ridge, TN 37831; prices available from (615)576-8401, FTS 626-8401.

Available to the public from the National Technicai Information Service, U.S. Department of Commerce, 5285 Port Royal Rd., Springfield, VA 22161. 


\title{
Proof-of-Concept Oil Shale Facility Environmental Analysis Program
}

\author{
Topical Report
}

Work Performed Under Cooperative Agreement No.: DE-FC21-90MC27084

\author{
For \\ U.S. Department of Energy \\ Office of Fossil Energy \\ Morgantown Energy Technology Center \\ P.O. Box 880 \\ Morgantown, West Virginia 26507-0880
}

\author{
By \\ Occidental Oil Shale, Inc. \\ P.O. Box 880408 \\ Steamboat Springs, Colorado 80488 \\ and \\ National Research Center for Coal and Energy \\ West Virginia University \\ Morgantown, West Virginia 26506
}




\section{EXECUTIVE SUMMARY}

Air Quality

Surface facility emissions

Non-point sources

Class I area proximity

Global atmospheric change

Visibility

Groundwater

IIa-1

MIS retort reclamation

Mine dewatering

Regional/local hydrology

Usage/augmentation

Surface Water

IIb-1

Usagelavailability

Process/mine water disposal/reuse

Runofflimpoundment

Spill prevention

Solid Waste

III-1

$C F B C$ waste

Process waste

Mine oil shale

Health and Safety

Surface Facilities - Toxic Substances

IVa-1

Mine Safety

IVb-1

Gassy mine rules

Retorting in mine environment

Shale oi! handling/transportation

IVc-1

Land

Subsidence
Reclamation

V-1

Vb-1

Biological - Wildlife

VI-1

Socioeconomic Analysis

VII-1

Electrical Transmission

VIII-1 


\title{
PROOF-OF-CONCEPT OIL SHALE FACILITY,
}

\author{
COLORADO TRACT C-b
}

\author{
ENVIRONMENTAL ANALYSIS PROGRAM \\ FINAL REPORT \\ Prepared by \\ National Research Center for Coal and Energy \\ West Virginia University
}

30 November 1990

\section{EXECUTIVE SUMMARY}

\section{Conclusion}

This report evaluates the environmental, health and safety aspects of Modified In-Situ (MIS) oil shale recovery and identifies outstanding issues which require consideration in the design stage of the Proof-of-Concept demonstration project. It also proposes areas which should be the focus for study during the project.

There appear to be no components of the project which would preclude proceeding. The environmental, health and worker safety issues examined by the expert teams are susceptable to treatment by either conventional technologies or technologies developed over the years by OOSI. Nevertheless, a number of significant issues remain such as effects on air and water resources, mine safety in the MIS environment, geotechnical and solid waste issues. It will remain for the Proof-ofConcept project to identify their impacts and to demonstrate remedial technologies as needed.

\section{Background}

Occidental Oil Shale, Inc. (OOSI), together with the Associated Governments of Northwest Colorado, Rio Blanco County, the State of Colorado and the United States Department of Energy, have devised a program to design, build and operate a demonstration plant that would use Occidental's Modified In-Situ (MIS) technology and a Circulating Fluidized Bed Combustor (CFBC) to produce oil and electric power from oil shale. Among other objectives, the project will evaluate the environmental, health and safety aspects of MIS technology.

As a result of the initial large scale oil shale activity in the 1970's a vast environmental database has been developed. West Virginia University's National Research Center for Coal and 
Energy was engaged in March 1990 to organize and manage a comprehensive review of environmental, health and safety issues associated with the project.

\section{The Proof-of-Concept Project}

The objectives of the Project are to demonstrate: 1) the Modified In-Situ (MIS) shale oil extraction process and 2) the application of CFBC technology using oil shale, coal and waste gas streams as fuels. The project will focus on evaluating and improving the efficiency and environmental performance of these technologies. The project will be modest by commercial standards. A 17-retort MIS system is planned in which two retorts will be processed sumultaneously. Production of 1206-barrels per calendar day of raw shale oil and 46-megawatts of electricity is anticipated.

West Virginia University coordinated an Environmental Analysis Program for the Project. Experts from around the country were retained by WVU to prepare individual sections of the report. These experts were exposed to all of OOSI's archives and toured Tract C-b and Logan Wash.

Their findings were incorporated into this report. In summary, no environmental obstacles were revealed that would preclude proceeding with the Project.

One of the most important objectives of the Project was to verify the environmental acceptability of the technologies being employed. Consequently, special attention will be given to monitoring environmental factors and providing state of the art mitigation measures. Extensive environmental and socioeconomic background information has been compiled for the Tract over the last 15 years and permits were obtained for the large scale operations contemplated in the late 1970's and early 1980's. Those permits have been reviewed and are being modified so that all required permits can be obtained in a timely manner.

\section{Technology}

The focal point of the Project was the Modified In-Situ (MIS) process. Some elements of MIS technology are proprietary to Occidental Oil Shale, Inc. (OOSI). The process is based upon retorting broken oil shale in place. It was successfully demonstrated by Retorts 7 and 8 at OOSI's Logan Wash research and demonstration site located near De Beque, Colorado.

The Project includes a CFBC for the production of steam for plant use and cogenerated electric power. The CFBC is fueled by a combination of MIS off-gas, shale and coal. All other supporting facilities (e.g. surface processing units and utilities) required to sustain operations are also provided.

Access to the tract will be made available to third parties to conduct testing of Above Ground Retorting (AGR), oil upgrading, benification and mining technologies subject to the consummation of mutually agreeable arrangements with OOSI, DOI, and DOE. 


\section{Capacity}

Two MIS retorts will operate simultaneously and produce 1,206 BPD of raw shale oil. Mined shale rock and MIS off-gas will be co-fired with other fuels in the CFBC to produce $35 \mathrm{MW}$ of cogenerated power. Some power will be consumed internally within the Project, with about $25 \mathrm{MW}$ being available for outside sales.

\section{DESCRIPTION OF THE ENVIRONMENTAL ANALYSIS PROGRAM}

The Program consists of a series or expert reviews within each of eight topic areas. Expertise was drawn from West Virginia, Colorado and Utah and includes both academics and private consultants. Each team includes leaders in their respective disciplines. Team leaders have made an inspection of OOSI's facilities, reviewed the available documentation within their topic area and have prepared reports addressing the topics outlined in Table 1. 
Table 1. Team leaders, assignments and anticipated sources of information for the Environmental Analysis Program, Proof-of-Concept Oil Shale Facility.

1. Air quality

Surface facility emissions

Non-point sources

Class I area proximity

Global atmospheric change

Visibility

EVALUATION TEAM LEADER: Michael Ratcliff, CPP Inc.

Ft. Collins, CO

QUALIFICATIONS: $\quad$ Ph.D. in Civil Engineering, Colorado State University; M.S. in Civil Engineering, University of Texas at Austin; B.S. in Atmospheric Science, University of Texas at Austin. Senior Project Engineer at Cermak Peterka Petersen, Inc., a wind consulting firm. Responsible for numerous building, pedestrian environment and pollution diffusion studies. Involvement with development of numerical diffusion models, data acquisition software and statistical analysis programs.

2. Water

Groundwater

MIS retort reclamation

Mine Dewatering

Regional/local hydrology

Usage/augmentation

EVALUATION TEAM LEADER: O. James Taylor, Consultant, Denver

QUALIFICATIONS: M.S. in Geology and Geochemistry, one year post graduate groundwater hydrology study, University of Arizona; B.S. in Geological Engineering, University of Arizona. While with the U.S. Geological Survey, developed the first hydrologic computer model of entire Piceance Basin to assist in design of mine drainage techniques for oil shale development. Over ten years experience in the oil shale field, published reports on mine drainage simulations, hydrologic simulations. Involved as a private consulting engineer in a study and report on solution mining of nahcolite and dawsonite in 
Piceance Basin, calculating the effects of groundwaters of different densities on vertical leakage in the Basin.

Surface water

Usage/availability

Process/mine water disposal/reuse

Runoff/impoundment

Spill prevention

EVALUATION TEAM LEADER: C. Robert Jenkins, Civil Eng., WVU.

QUALIFICATIONS: $\quad$ Ph.D. in Zoology, Sanitary Engineering, Oklahoma State University; M.S. in Zoology, University of Illinois; B.S. in Chemistry, Eastern Illinois State College. Director, Water Research Institute; Professor of Civil Engineering, West Virginia University; appointed member of West Virginia Water Resource Board. Consultant to government and industry on hazardous waste, water analysis, water treatment. Research areas include water quility, treatment and analysis, wastewater treatment and aquatic biology.

3. Solid Waste

CFBC waste

Process waste

Mined oil shale

EVALUATION TEAM LEADER: John C. Bowders, Civil Eng., WVU.

QUALIFICATIONS: $\quad$ Ph.D. in Geotechnical Engineering, University of Texas at Austin; M. S. in Geotechnical Engirieering, Drexel University; B.S.C.E., Drexel University. Areas of research interest and consultancy in land disposal of hazardous wastes, laboratory measurement of engineering properties of soils, foundation engineering, stability of earth slopes, reclamation of surface mined lands, and control of acid mine drainage.

4. Health and Safety

Surface facilities-toxic substances

EVALUATION TEAM LEADER: Mario Battigelli, Dir. OHS, School of Medicine, I.VU. 
QUALIFICATIONS:

M. D., specialty in industrial toxicology, University of Milan, Italy; M.D., speciality in public health and occupational medicine, University of Pittsburgh; M.P.H., University of Pittsburgh. Currently Director of the Institute of Occupational Health and Safety of the Schhol of Medıcine, West Virginia University. Faculty positions at West Virginia University, University of Florence, University of Milan, University of Pittsburgh, University of North Carolina, Duke University Medical Center and the University of Utah. Has studied effects of air pollution and adverse environmental exposure for 35 years, led research projects in industrial and environmental toxicology, with publications in journals and textbooks.

Mine safety

Gassy mine rules

Retorting in mine environment

Shale oil handling/transportation

EVAluation TEAM LEADER: Syd S. Peng, College of Mining and Energy Resources, WVU.

QUALIFICATIONS: Ph.D. in Mining Engineering (Rock Mechanics), Stanford University; M.S. in Mining Engineering (Rock Mechanics), South Dakota School of Mines and Technology; P.E. in Mining Engineering, Taipei Institute of Technology. Professor and Chair, College of Mineral and Energy Resources, West Virginia University; Previously head of Rock Physics Research, U.S. Bureau of Mines. Consultant to USDOI BOM, US DOE, US BOM OSM, 82 state agencies, coal mining, consulting and equipment manufacturing companies.

EVAlUATION TEAM: Ronald R. Rollins, College of Mining and Energy Resources, WVU.

QUALIFICATIONS: B.S. in Fuels Engineering, University of Utah, Ph.D. in Metallurgy, University of Utah. Specialization in explosive engineeering, rock fragmentation, blasting, and explosive theory taught in two graduate level courses and one undergraduate level course. Organized and presented short courses on blasting, rock fragmentation, blast round design, explosive theory and and blast casting. 
A. Wahab Khair, College of Mining and Energy Resources, WVU.

QUALIFICATIONS: B.S. in Mining Engineering, West Virginia University; M.S. in Mining Engineering, West Virginia University; Ph.D. in Mining Engineering, The Pennsylvania State University. Professor, Department of Mining Engineering, West Virginia University; President of National Coal Industry and Advisor to Minister of Mines and Industries, Kabul, Afghanistan. Responsible for administration, mine planning, coal haulage, surface transportation, and engineer in-service training. As part of the training, gave short courses on safety, ventilation, survey, and mine design.

5. Land

Subsidence

EVAluAtion TEAM LEADER: Syd S. Peng, College of Mining and Energy Resources, WVU.

QUALIFICATIONS: (see above)

Reclamation

EVALUATION TEAM LEADER: Jeff G. Skousen, College of Agriculture, WVU.

QUALIFICATIONS: $\quad$ Ph.D. in Range Revegetation, Texas A\&M University; M.S. in Botany and Range Sciences, Brigham Young University; B.S. in Botany and Range Sciences, Brigham Young University. Revegetation and reclamation specialist in the intermountain, Texas lignite ani Appalachian coal regions for the past 10 years. Published scientific research and popular articles in all three areas.

6. Biological

Endangered/threatened species

Deer herds

EVALUATION TEAM LEADER: James T. MacMahon, College of Science, Utah State University

QUALIFICATIONS: $\quad$ Ph.D. in Biology, University of Notre Dame; B.S. in Zoology, Michigan State University. Dean of the College of Science and Professor of Biology, Utah State University. Studied disturbed lands, specifically surface 
mine land reclamation in the western United States, for 20 years; has a national and international reputation as an ecologist. Director of 9 year project on reclamation of mine spoils in Wyoming. Published two books, in excess of 100 scientific papers in his field.

7. Socioeconomic analysis

EVALUATION TEAM LEADER: Dennis Stranger, Management and Planning Research, Inc. Glenwood Springs, CO

QUALIFICATIONS: $\quad$ B.A. in history and political science, Regis College, Denver, CO; M.S. in Environic Design, University of Notre Dame. Consultant in management and planning research, involved in economic and socioeconomic assessments for numerous large scale energy development projects. Chaired the Colorado Joint Review Process teams coordinating permitting and EIS reviews for the Clear Creek Shale Oil Project, Phase II of the Unocal Parachute Creek Shale Oil Program and the Pacific Shale Oil Project. Prepard the Indiana Shale Oil Development Project.

8. Electrical power transmission

EVALUATION TEAM LEADER: Frank Calzonetti, Assoc. Dean, College of Arts and Sciences, WVU

QUALIFICATIONS: $\quad$ Ph.D. in Geography, Oklahoma University; M.A. in Geography, Wayne State University; B.A. in History, Wayne State University. Author or co-author of four books on energy facility location. Served as gubernatorial consultant on West Virginia electricity export activities. Directed the American Electric Power Service Corporation's power plant siting evaluation. Co-Principal Investigator for the APCO $765-\mathrm{kv}$ transmission line siting project. Directed research projects on energy faciltities and industrial location for the U.S. Development Administration; the Argonne National Laboratory. Consulted to the Oak Ridge National Laboratory on energy facility waste siting project. 
The eight evaluation teams were under the direction of the project manager, Dr. P.F. Ziemkiewicz, Program Direcior, National Research Center for Coal and Energy. The project manager was responsible fur ensuring that tasks were assigned and completed on time and coordinated project reports. The evaluation team leaders were responsible for preparing their evaluations and submitting them on time. The project manager was also respc sible for administering the research agreement with OOSI and managing the project funds.

\section{ENVIRONMENTAL SETTING}

\section{Location}

Prototype Oil Shale Tract C-b is located in the sparsely populated Piceance Creek Basin in northwestern Colorado. The Tract comprises nearly 5,100 acres of federally-owned land situated approximately 40 miles from the towns of Meeker and Rifle, and 65 miles from Rangely, CO.

\section{Geology and Soils}

The C-b Tract is near the center of the Piceance Basin. It sits on gently rolling topography at elevations from 6500 to $6800 \mathrm{ft}$. above sea level. The basin consists of rocks of the Wasatch, Green River, and Uinta Formations which are exposed along the Basin's periphery and downwarped so that older beds are deeply buried. The Green River and younger Uinta formations encompass three lithologic zones that are pertinent to the geology of the Trat: a basal fresh water shale (the Garden Gulch member), a middle dolomitic oil shale and associated saline deposits (the Parachute Creek member), and an upper clastic unit (Uinta Formation). Alluvial deposits of varying thickness are found in the major stream valleys and up the larger draws; undifferentiated alluvial-colluvial deposits are found on valley side slopes and on the divides.

The Parachute Creek member of the Green River Formation is composed almost entirely of organic-rich marlstone (oil shale). The richness of the Parachute Creek oil shales varies both vertically and laterally, and this is subdivided into a number of units based on richness and other properties. Around the margin of the basin, rich oil shale (greater than 25 gallons per ton (gpt)) is restricted to a unit in the upper part of the member called the Mahogany zone. It averages about 100 feet in thickness but reaches a maximum thickness of more than 200 feet.

Oil shale in the lower part of the Parachute Creek member (below the Mahogany zone) has been referred to as the Lower Rich zone. it reaches a maximum thickness of about 1200 feet and has a maximum richness in excess of $30 \mathrm{gpt}$ near the basin depocenter and grades laterally to less than $10 \mathrm{gpt}$ toward the margin of the basin.

There are seven soils series on Tract C-b and in the surrounding area. All have origins in the Tertiary Uinta Formation, which is comprised of interbedded and highly fractured massive sandstones, siltstone, and shale. The texture of the soils vary from light to medium. The relative 
concentrations of constituents are as follows: organic matter, moderate; lime, high; calcium, high; and manganese, moderate. Most soils are suitable for wildlife habitat and grazing.

\section{Surface Water}

There are several gulches on the Tract; their channels are ephemeral and generally dry. Drainage on the Tract is tributary to Piceance Creek, which is just north of the Tract. The Tract is in the watershed of the Colorado River, via the White River.

Typically the total dissolved solids (TDS) in Piceance Creek varies from about 700 milligrams per liter (mg/1) just upstream on Tract C-b to about $950 \mathrm{mg} / \mathrm{l}$ below the Tract. The TDS are approximately $1800 \mathrm{mg} / 1$ at the mouth of Piceance Creek. Numerous springs occur in the reaches of Piceance Creek; several discharge water with high concentrations (up to $20,(0) 0 \mathrm{mg} / \mathrm{l}$ ) of dissolved salts. On the C-b Tract the waters cover a range of low-to-moderate concentrations of dissolved solids (to $1500 \mathrm{mg} / 1$ ).

\section{Groundwater}

The stratified nature of the rocks of the Piceance Basin results in a sequence of flat lying layers of sedimentary rocks that vary greatly in porosity and in horizontal and vertical permeability. Groundwater occurs in several strata throughout the Piceance Basin. The principal water bearing zones are in the Uinta and Green River Formations; the underlying Wasatch Formation has very low permeability and a general lack of primary and secondary porosity.

The Green River Formation has been divided into several lithologic units based on depositional history. The Garden Gulch member, comprised of marlstone and lean oil shale, yields very little water to wells. It is relatively impermeable and forms the lower boundary of the aquifer system in much of the Piceance Basin. The overlying Parachute Creek member contains more permeable zones which can yield as much as 1000 gallons per minute (gpm) in wells. The MIS retorts will be located in the Mahogany and R-6 zones of the upper Parachute Creek Member. The highly permeable Leached Zone, which is the major water producing zone is below the target zone.

The Uinta Formation overlies the Parachute Creek member and forms the surface rock over most of the basin. Wells completed in this Formation can yield as much as $300 \mathrm{gpm}$, although yields less than $100 \mathrm{gpm}$ are more common.

The water in the alluvium is of sodium bicarbonate type. The concentration of dissolved solids averages approximately $1750 \mathrm{mg} / 1$. The water in the upper aquifer is classified as sodium bicarbonate type and generally contains moderate concentrations of sulfate and low concentrations of chloride and fluoride. Chemical characteristics of water in the lower bedrock wells are of definite sodium biocarbonate type with higher chloride and fluoride concentrations and lower sulfate concentrations that water from the other aquifers. The concentration of dissolved solids generally ranges from less than $500 \mathrm{mg} / 1$ to nearly $40,000 \mathrm{mg} / 1$. 


\section{Air Resources}

Topography of the Piceance Creek basin and surrounding regions strongly influences the wind patterns and the dynamics that govern the transport and diffusion of air contaminants. In the free atmosphere above 9,000 feet elevation, the prevailing winds are from the southwest and westsouthwest throughout the year. Near the surface, both speed and direction are strongly dependent upon terrain characteristics and the local thermal environment.

Thunderstorms, often of short duration but high intensity, may cause flash floods in the region during late summer. The fall season tends to be dry and mild, punctuated occasionally by an early fall snowstorm. Late spring snowstorms can occur up through the end of May.

Snowfall occurs on an average of 20 days and total cumulative amounts of 80 inches can occur in the Piceance Creek valley, and more than 100) inches can occur on the plateau top. Average precipitation is about 14-16 inches most of which comes in the form of snowfall.

Air temperatures are strongly influenced by terrain and air flow patterns. During spring, summer, and autumn, air temperatures are generally moderate, and even in mid-winter, afternoon maximums are usually in the mid 40's ( $\left.{ }^{\circ} \mathrm{F}\right)$. As a result of cold air drainage and stagnation, however, midwinter minimum temperatures are occasionally extremely low (e.g., $-55^{\circ} \mathrm{F}$ ). Frost is more common in valleys than on mesa tops because of air stagnation.

With occasional summertime maxima over $1(x)^{\circ} \mathrm{F}$, the annual range of temperature can exceed $150^{\circ} \mathrm{F}$. The number of frost free days varies from 50 days in the higher elevations above 8000 feet to 125 days in the lower elevations under 5,500 feet. The dry climate and short growing season have a limiting effect on the total biomass productivity of the Basin.

The Piceance Creek basin is largely undeveloped and substantially free from atmospheric pollution other than particulates and other contaminants caused by natural occurrences or by longrange transport.

\section{Biological Resources}

The flora and fauna of the region are distributed in a complex mosaic of types controlled by climate, soils, topography, and human disturbance. The region has a semi-arid climate, and many of the plants in the region are adapted to dry conditions. Localized moist conditions, such as those around stream bottoms, support a greater variety of plant and animal habitats.

Agricultural practices of early settlers changed the landscape by reducing tall grasses and trees in valley bottoms. In modern times, chaining practices to remove trees were implemented by the Bureau of Land Management (BLM) to improve domestic livestock and wildlife carrying capacities by increasing range production. As a result, large areas of pinyon pine and juniper trees are downed 
on some ridgetops, while grasses and shrubs have proliferated in the absence of the tree canopy. Approximately 45 percent of the Tract was chained in 1966-67.

The principal vegetation types found on Tract C-b are distributed over much of the Piceance Basin. None are unusual in species, composition, or structure. All have been subjected to the influences and disturbances related to livestock grazing, cultivation, mechanical range improvement, or other human activities.

Mule deer are abundant in the general vicinity of the Tract. The deer in this locality live principally at higher elevations during summer, but from fall through spring larger numbers remain close to the Tract itself. The Tract is part of the total winter range for the deer of the Piceance Creek basin. Elk are occasionally seen on the site. They appear to be more common at higher elevaton hillsides south of the site. There are a minimum of thirteen species of medium-sized mammals identified within the Tract area. The coyote, yellow-bellied marmots, and white-tailed jackrabbits are common Tract residents. The desert cottontail and snowshoe hare are the only small game mammals identified on Tract $C-b$, but only the desert cottontail occurs in any abundance. The diversity of birds (over 160 varieties) on the Tract is impressive considering the general dry environment and limited riparian and aquatic areas.

There are no rare and endangered species (plants, fish, etc.) on Tract C-b or in Piceance Creek.

\section{ANAL YSIS OF ENVIRONMENTAL, HEALTH AND SAFETY ISSUES}

Following are summaries extracted from the final reports of the expert teams. The summaries indicate the extent of knowledge identified in each area and, most significantly, begin to identify the key, unresolved issues so that the Pronf-of-Concept Project may focus on environmental, health and safety issues of highest priority.

I. AIR QUALITY. Air quality degradation from major sources is regulated by the federal Clean Air Act and Colorado Department of Health regulations. Appropriate permits must be obtained before operation. Occidental Oil Shale, Inc. (OOSI) appears to have complied with regulations as existed when the 1985 revised detailed development plan (RDDP) was written. OOSI is proceeding with an updated permitting process including emissions from the new Circulating Fluidized Bed Combustion unit (CFBC). Ambient monitoring of regulated pollutants will be performed during operations to ensure compliance. Air quality selated values, such as visibility and dry deposition, have also been examined.

OOSI has anticipated some possible future regulations: a plan for capturing and marketing carbon dioxide should global warming provisions be adopted in the upcoming Clean Air Act amendments; and monitoring of elemental toxics from CFBC emissions and in ambient air is planned. Other revisions on the way, such as Clean Air Act Amendments, PSD increments for $\mathrm{NO}_{\mathrm{x}}$ and $\mathrm{PM}_{10}$ will need to be dealt with as they are promulgated. 
A few issues are raised which may need further explanation or investigation: the need for simple terrain as well as complex terrain dispersion modeling for permitting, the inclusion of Dinosaur and Colorado National Monuments as Class I areas, possible inclusion of arsenic and radionuclides in de minimus emission levels for PSD, and the possible permitting of arsenic under Colorado air toxics regulations. Pilot plant tests using various blends of oil shale and coal indicate that all toxics per the 1990 federal Clean Air Act fall below de minimus levels.

II a. GROUNDWATER. Field data and hydrologic analyses suggest that additional pumping for mine drainage for the proposed project may not affect the flow of Piceance Creek, but uncertainties remain concerning the hydraulic connections among the creek, alluvial aquifer, and bedrock aquifers. Collection of hydrologic data needs to continue, and these data should be analyzed for trends during the project. In addition, a local study of the hydrologic characteristics of the valley fill alluvium is recommended.

After the retorts are burned, they need to be flushed repeatedly with water to stop pyrolysis, cool the retorts, flush sediment, and dissolve expected organic and inorganic materials from the retorts. The flushing needs to continue until measurements of the quality of the water used for flushing indicate that the retorts will not contaminate invading groundwater.

Upon abandonment, groundwater will resaturate the retorts and reestablish the natural flow system. Few problems are expected with groundwater contamination in abandoned retorts, if the retorts are thoroughly flushed prior to flooding. However, water quality monitoring is needed within the retorts, and in observation wells nearby to ensure that groundwater contamination does not occur.

II b. SURFACE WATER. A preliminary water budget, relative to the proposed MIS process with associated CFBC power plant has been prepared by OOSI. It indicates the principal water streams required by and produced by various components of the system: mine dewatering, bulkhead water collection, processing, boiler feed, boiler blowdown and cooling systems.

The quality of water emanating from quenched retorts is of particular interest. It is likely that it will be saline and alkaline. The toial organic content has been shown to decline over time for similar retorts at Logan Wash. Total dissolved solids in water used to flush the retorts has so far remained high. A definition of what constitutes a satisfactorily reclaimed spent retort has not been finalized. There are no plans to discharge process water to receiving streams and, indeed, the NPDES discharge permit prohibits any discharge other than treated mine water. All excess water is to be evaporated, either through quenching of retorts, by spraying on the boiler ash pile or in an evaporation pond. Process water streams which contain significant organic compounds will be incinerated in the CFBC. 
The lease stipulations and the NPDES discharge permit call for strict control of surface discharge and the resultant protection of Piceance Creek. Based on the information that is available no unsolvable problems regarding surface water protection have been detected.

III. SOLID WASTES. The project will generate two types of solid wastes: boiler ash and oil shale. Oil shale is known to be an innocuous material. Boiler ash is a new material and has only recently been generated and studied.

Boiler ash will be generated from the Circulating Fluidized Bed Combustor (CFBC). It will consist of combusted oil shale and coal. This material will be disposed in surface dumps. The amount of ash to be generated is estimated to range from a peak of 380,000) to a low of 200,000 TPY stabilizing at about 290,000 TPY after completion of MIS development.

The low inherent permeability of CFBC ash will tend to isolate it from precipitation water. A leachability study of the CFBC ash is underway. Preliminary results indicate that neither RCRA metals nor organic compounds exceed the regulatory limits. The indication from this work is that the ash will not present an environmental threat. Previous studies have shown that the raw rock (non-retorted oil shale) does not present significant pollution threats when disposed in landfills. Field studies regarding the leaching and permeability characteristics of the boiler ash should be considered. It is anticipated that the results of such a study would confirm the laboratory findings regarding the leachate characteristics of the ash.

Specific plans for dealing with disposal of the solid wastes generated from the C-b site are still being developed. Preliminary reports indicate that the solid waste derived from the mining of oil shale would be disposed of in a fill located in the valley immediately adjacent to the mine shafts (where material previously mined from the shafts has been placed). It is not currently expected that a surface retort will be operated during the demonstration and there are no specific plans for disposal of retorted shale.

IV a. HUMAN HEALTH AND SAFETY. The production of oil shale encompasses a range of operations which are associated with potential and/or real exposure to both solid and gaseous contaminants.

Workers at this operation may therefore experience contaminants in different physical and chemical states. In addition, health risks connected with the technology of inining, construction, maintenance, operation of a refinery plant, transportation, distribution and testing all may contribute to the specific and unusual threats of oil shale production/use.

None of these risks are exclusive to this industry and none can be considered unprecedented or uncontrollable. Indeed, traditional means of safety and of industrial hygiene care are applicable to this particular setting, just as they are applicable to the mining industry in general. 
General worker health control measures used in other extractive industries should be equally applicable in MIS technology.

IV b. MINE SAFETY. Gas is present in the oil shale strata of the Green River formation. The C-b oil shale mine has been classified as a gassy mine by MSHA since january 2, 1980 based on a sample containing $0.289 \%$ methane. This can be controlled by adequate ventilation and according to OOSI personnel at the $\mathrm{C}$ - $\mathrm{b}$ site no methane has ever been detected by the automatic sensors that are constantly monitoring the mine and the shafts.

Most of this methane probably comes from groundwater. The problems associated with gas liberated from water inflows have been identified, but since the mining horizons are dry and most water comes from the shafts, the gas will either be highly diluted with intake air or immediately exhausted to the surface. Current estimates of groundwater gas are $48 \mathrm{CFM}$ and diffusion gas of 5 CFM for a total of 53 CFM. To dilute this to $0.1 \%$, only 53,000 CFM of ventilation air will be required. This will pose no problems.

As in any fissile shale, oil shale is subject to spalling. The primary area where this is of concern is in the roofs of the underground tunnels, where the safety of personnel and equipment are of concern. OOSI's C-b facility has successfully used roof bolting and wire mesh to control roof fall five years after construction.

Based on a review of the documentation provided and the site visit, it is the reviewer's opinion that the OOSI MIS technique is a technically viable option from the perspective of mine worker safety.

IV c. SHALE OIL HANDLING/TRANSPORTATION. This report presents an evaluation of shale oil handling and transportation, with respect to health and safety, in reactivating Occidental Oil Shale Tract C-b operation near Meeker, Colorado. Assessment of proposed processes and technology associated with the above mentioned products was made from reports provided by Occidental Oil Shale, Inc. (archives of Occidental Oil Shale in Pallisade, Colorado), and also from discussions held with Occidental personnel at C-b and Logan Wash sites during tours, April 11, 1990. Evaluation of the proposed process and technology was made based on their compatibility with state of the art.

There are two options for transportation of the shale oil. Option one would have trucks haul the oil to Unocal's upgrader at Parachute Creek, Colorado. It is estimated that this would mean nine tanker truckloads per day and not place any significant burden on the route. Option two involves transporting of unupgraded shale oil by truck to a railhead, probably Rifle, Colorado, thence by rail to remote markets. Both options include conventional technology and no problems are anticipated.

V a. SUBSIDENCE. Two mine development plans were proposed during research and development programs of the 1980's. The first mine plan involves only clusters of MIS retorts laid out in panel form. The second plan consists of two parts: one is a room and pillar mining section 
and the other is an MIS section. Subsidence prediction was performed to determine the size of the shaft pillar using the British National Coal Board method in 1975 and that proposed by Abel and Lee in 1980. The panels were designed not to subside. But the pillar design methods by two separate groups produced considerable differences in pillar strength (2180 psi vs. $670 \mathrm{psi})$.

This discrepancy' must be resolved. The subsidence prediction techniques used in this project were developed by the British National Coal Board which has been proven unsuitable for U.S. coalfields. Several new techniques have since been developed for U.S. coalfields. These should be investigated for application in oil shale. OOSI plans to conduct coring and other in-mine testing during the initial phases of the Project in order to verify the factors used in the design of a nonsubsiding mine.

V b. RECLAMATION. Disturbance of land in the Proof-of-Concept Facility will be limited to the construction of a boiler ash dump and possibly a spent shale dump. Reclamation of surface disturbances around injection holes, coring operations, and installation of the MIS gas collection shaft present few problems to revegetation specialists. Revegetation of such sites can be done quickly and effectively.

Revegetation of boiler ash has not been studied. However, retorted or spent oil shale has been studied extensively. Boiler ash is likely to be similar to spent shale and differs primarily in the addition of some proportion of coal ash and the amount of carbon remaining in the ash. Some spent shales have carbon residues of +4 weight percent while boiler ash carbon content will be much lower (less than 1 percent) and has properties like "Lurgi" spent shale. The characteristics of spent shale commonly causing problems relative to revegetation are coarse particle size, dark color, high salt content, and low amounts of nitrogen and phosphorus.

Practices used to overcome deleterious properties of raw and spent shale are topsoiling, addition of organic matter, fertilization, mulching, irrigation, and seeding of adapted plant species.

Upon review of numerous scientific experiments conducted over the past 30 years in the area and analysis of demonstration plots constructed at the C-b site, revegetation of surface disturbances, of raw and processed shale piles, and of boiler ash dumps created during the project will not present major challenges. The experimental and demonstration revegetation trials demonstrate that with careful planning and timely application of topsoil, amendments, and seed from adapted plant species, revegetation can be successfully accomplished and completed concurrent with project operations.

State and federal revegetation requirements concerning plantcover and productivity can also be met. Environmental concerns relative to deposition of raw and processed shale and boiler ash on the surface and their revegetation are not warranted when recommendations for their revegetation are followed.

VI. WILDLIFE. The background documents that have been assembled to evaluate the influences of oil shale development on wildlife provide an accurate representation of the status of wildlife and 
the prospects of the effects of development of the oil resource on a wide range of wildlife species including both game and non-game species. Most of the baseline studies related to C-b Tract were conducted between 1974 and 1980. Despite the ten year interval since the last detailed studies, there is no obvious reason to question their current validity. Given that this is the case, the analysis of wildlife presented in section 2.5 of the Revised Detailed Development Plan-1985 is considered to be an acceptable representation of the status of wildlife on the Tract.

The results of the current analysis suggest that the Proof-Of-Concept study will have few, if any, negative impacts on the populations of wildlife species. In fact, the proposed study may be the only reasonable way to collect data to evaluate the actual impacts of the MIS technology on wildlife. The proposed demonstration will be sufficiently small in scale that if there are negative impacts, they will be minor. Data from this experience should allow us to scale-up to the potential impacts of commercial level shale oil production.

VII. SOCIOECONOMIC ASSESSMENT. The Proof-of-Concept Oil Shale Project, to be loca'ed on the federal oil shale lease Tract C-b in western Colorado, will be constructed and operated over a ten $y$ ' $x$ period. The socioeconomic effects of the project are positive.

It is estimated that the project will directly employ 546 construction workers in the peak year of construction activity and 285 operation workers in the peak year of operations. Total direct employment will range from 59 to 690 over the life of the project with an average direct employment of 268 workers.

The development of the project vill result in increased employment, personal income and public tax flows. Revenues will flow to local government jurisdictions, the State of Colorado and the federal government. Direct public revenues alone will amount to approximately $\$ 20$ million for state and local governments. $\$ 141$ million will be paid to project workers directly in the form of payroll wages with estimated indirect wages amounting to $\$ 169$ million for the ten year life of the project.

The project-related population represents only slightly over one percent of the population of the region and can be easily accommodated by existing towns and cities in the area. No adverse public impacts have been identified to date. The construction and operation of the project presents an opportunity to develop technical expertise in oil shale mining and processing with minimal socioeconomic impacts. It is anticipated that socioeconomic information collected during the Proofof-Concept project will facilitate permit acquisition and socioeconomic impact mitigation for commercial oil shale development projects.

VIII. ELECTRICITY TRANSMISSION. The Proof-of-Concept operation will not require the construction of new transmission capacity, only minor modifications of existing switchyards (both at the C-b site and at Meeker). The existing 138-kv line will be used to sell cogenerated power. The environmental, health and safety impacts possibly arising from the $138-\mathrm{kv}$ transmission line are discussed in the February 19, 1980 Environmental Assessment, and the topic will be considered in a new Environmental Impact Statement. The 1980 report shows that the existing 138-kv line was 
constructed according to standards described in Electric Transmission Specification and Drawings, REA Form 805 (Rev 2-73) and by the sixth edition of the National Electric Safety Code. Also, since the line would be crossing an area with a raptor population, the pole structures were designed according to REA Bulletin 61-10 (March 9,1979) Powerline contacts by eagles and other large Birds to minimize impact of the line on raptors.

In the event of full-scale comercial development, a second line would follow the existing right-of-way. In this event, the present right-of-way would be evaluated for its potential to include an additional transmission line. This additional transmission capacity would only be required by a significant expansion at the C-b site (e.g. to 50,000 bbls./day capacity).

\section{INFORMATION NEEDS}

The Proof-of-Concept project is a unique opportunity to evaluate the environmental, health and safety aspects of MIS oil shale technology on a small, manageable scale. Many of the components of this report will be subject to monitoring over the life if the project and the monitoring program will serve to verify or challenge our recommendations. Specific components of the monitoring program are suggested in the appendicies.

In addition, several key items were identified which should serve as the focus for information gathering programs during operations. These are listed below.

\section{Air quality}

Simple terrain dispersion models rather than the VALLEY dispersion model should be evaluated before and over the course of the project. In addition, the operating variances in emissions should be characterized and figured into any dispersion modelling.

\section{Water}

The key unresolved water issues relate to the impact of mine drainage on the stream system and water quality concerns. One of the objectives of the demonstration project is to monitor the streamflow and the water quality during actual development. Only then will the true impacts of development on the water resources be known.

When the burned retorts are abandoned and flooded, the water quality of the invaded water within and near the retorts should be monitored. It is possible that poorly soluble contaminants not flushed previously may go slowly into solution in the local groundwater. 
There does not seem to be a definition as to what constitutes a satisfactorily leached retort. Authorities from regulatory agencies and OOSI should develop an agreement stipulating the character of water to be allowed to accumulate in spent retorts.

\section{Solid Waste}

The rate of boiler ash production will average about 300,000 TPY. Engineering designs for disposal sites are not yet prepared.

The chemical and physical nature of boiler ash is not precisely known. These are simple parameters to identify and should be available soon. In addition, geotechnical parameters should be identified such as: friction angle, cohesion, maximum density, optimum water content, permeability, pozzolanic reactivity. These parameters will facilitate the design of stable dump slopes.

\section{Health and Safety}

An employee monitoring program should be implemented. This monitoring would begin with the pre-employment scrutiny, to eliminate factors of accrued risk, in terms of the individual propensity toward injury or aggravation from exposure of conditions pre-existing employment. Following this baseline appraisal, a periodical surveillance program would monitor both exposure. and possible effects.

The reviewer found no unresolved issues from a gassy mine rules or retorting in mine environment standpoint. These issues have been adequately addressed.

Other than the exact volume of coal to be moved to the plant, issues related to off-site transportation are straightforward and subject to current safety practices.

\section{Land Subsidence, Reclamation}

The oil shale rock strength developed by two separate groups shows considerable difference. Thus the pillar strength issue should be reviewed with any new data incorporated into the analysis and a consistent value should be derived based on sound engineering practice. Strength properties of spent shale in the retorts must be determined for evaluation of collapse and confinement potential.

The technology, as presently practiced for revegetation of raw and spent shale piles and surface disturbances, seems adequate to complete the job as specified under current reclamation laws. Topsoiling, fertilization, mulching, irrigation, and plant species selection are all important for successful revegetation of spent shale and boiler ash piles. These issues are addressed in the reclamation plan. It is expected that boiler ash piles will require similar treatment in order to ensure successful revegetation. 


\section{Biologica!}

There is no obvious issue that needs to be addressed that has not been addressed. Endangered species have not been identified on the site, to date. The small scale of the project probably precludes major wildlife impacts at this time.

\section{Socioeconomic analysis}

There do not appear to be any significant unresolved socioeconomic issues associated with the Proof-of-Concept project. It is not known if specific socioeconomic assessment requirements for Rio Blanco County and federal permits have been satisfied ac this time.

\section{Electrical power transmission}

The Proof-of-Concepr project will not require additional transmission capacity. Upon identification of markets for the produced electricity it will be possible to evaluate required changes in the system downstream from the plant site. Such changes are expected to be in the nature of switching equipment, none of which are considered major items.

\section{CONCLUSIONS}

Among the key objectives of the Proof-of-Concept project will be evaluation of th impacts of MIS technology on key environmental, health and safety issues. It represents a long-term, demonstration and development stage prior to full scale commercial operutions. The scale of the Proof-of-Concept project will be such that processes and procedures can be modified over its course so as to achieve a technology which is not only efficient, but safe for workers, the public and the environment. This report identifies whether any outstanding problems are likely to emerge which require attention in the design portion of the Proof-of-Concept project. It also proposes areas which should be the focus for study during the project. These are listed in the above section.

In short, there appear to be no components of the project which would preclude proceeding. The environmental, health and worker safety issues examined by the expert teams are susceptable to treatment by either conventional technologies or technologies developed over the years by OOSI. Nevertheless, a number of significant issues remain such as effects on air and water resources, mine safety in the MIS environment, geotechnical and solid waste issues. It will remain for the Proof-ofConcept project to identify their impacts and to develop remedial technologies as needed. 


\begin{abstract}
APPENDICES
Appendices I to VIII are outline reports prepared by each of the expert team members. They reflect the degree of documentation available by late April 1990. In general there was little detailed information available on the nature of boiler ash, retort and process water. To the extent that information on each of the topic areas was limited with respect to the proposed MIS/CFBC technology information was drawn from the 1985 Revised Detailed Development Plan for a much larger ( 80,000 bpd) operation.
\end{abstract}




\section{APPENDIX I}

1. Topic Area: $\quad$ AIR QUALITY

2. Subtopic: $\quad$ N/A

3. Review Team Leaders: Michael A. Ratcliff and Ronald L. Petersen, Cermak Peterka Petersen, Inc.

\section{ABSTRACT}

Air quality degradation from major sources is regulated by the federal Clean Air Act and Colorado Department of Health regulations. Appropriate permits must be obtained before operation. Occidental Oil Shale, Inc. (OOSI) appears to have complied with regulations as existed when the 1985 revised detailed development plan (RDDP) was written. OOSI is proceeding with an updated permitting process including emissions from the new Circulating Fluidized Bed Combustion unit (CFBC). Ambient monitoring of regulated pollutants will be performed during operations to ensure compliance. Air quality related values, such as visibility and dry deposition, have also been examined.

OOSI has anticipated some possible future regulations: a plan for capturing and marketing carbon dioxide should global warming provisions be adopted in the upcoming Clean Air Act amendments; and monitoring of elemental toxics from CFBC emissions and in ambient air is planned. Other revisions on the way, such as PSD increments for $\mathrm{NO}_{\mathrm{x}}$ and $\mathrm{PM}_{10}$, will need to be dealt with as they are promulgated.

A few issues are raised which may need further explanation or investigation: the need for simple terrain as well as complex terrain dispersion modeling for permitting, the inclusion of Dinosaur and Colorado National Monuments as Class I areas, possible inclusion of arsenic and radionuclides in de minimus emission levels for PSD, and the possible permitting of arsenic under Colorado air toxics regulations.

\section{SUMMARY OF FINDINGS TO DATE}

The main provision of the Clean Air Act is the National Ambient Air Quality Standards (NAAQS) which prescribe concentration levels for several criteria substances, sulfur dioxide, nitrogen oxides, lead, particulates (less than $10 \mu \mathrm{m}$ diameter), ozone and carbon monoxide, that should not be exceeded. Emissions from all sources and background concentrations are included when comparing concentrations to the standards. Compliance wis demonstrated in the 1985 RDDP for all pollutants, excepting lead which was assumed to have negligible emissions. Compliance was shown by adding measured background levels with maximum expected concentrations from dispersion modeling.

Particulates with diameters less than $10 \mu \mathrm{m}\left(\mathrm{PM}_{10}\right)$ have replaced total suspended particulates (TSP) in the NAAQS since the RDDP was written in 1985. This will necessitate different ambient 
sampling equipment, revised emission estimates, and additio.ial dispersion modeling, as was anticipated in the 1985 RDDP.

For areas which are in attainment of NAAQS, prevention of significant deterioration (PSD) regulations apply. PSD has broäd implications $\mathrm{n}$ emissions controls, allowable increases in ambient levels, ambient menitoring before and after construction, and minimization of effects on soil, vegetation, and air quality related values such as visibility. The 1985 RDDP appears to address all necessary aspects of PSD, as discussed below.

PSD regulations set allowable increases in ambient concentrations above background due to all sources ("increments"). PSD increments are at present established only for sulfur diuxide, nitrogen oxides, and total suspended particulates. Nitrogen oxides are a recent addition, and full implementation is scheduled for November 1990 (FR 40656, Oct 17, 1988). Background values are established with ambient monitoring at some specified baseline time. Other significant sources in the area (information provided by the state) must be included in the dispersion modeling.

Tradeoffs ("bubbles", "offsets", and "nettings") of emissions within groups of nearby similar sources are allowed in certain circumstances. This reduces the overall cost by allowing the emitter credit for more controls on easier to control sources. Tradeoffs were not explicitly used in the 1985 RDDP.

There are two classes of areas each with differing sets of allowable increments; a third class is not used in practice. Class I areas include national parks and wilderness areas. Class II includes all areas in compliance with NAAQS which are not Class I.

With dispersion modeling, the 1985 RDDP has shown compliance in the two nearest wilderness areas: Flattops and Mt. Zirkel. However, Colorado Regulation No. 3 (section VIII.B.) also includes several national monuments for $\mathrm{SO}_{2}$ only, including Dinosaur National Mionument, about $75 \mathrm{~km}$ away, and Colorado National Morument, $90 \mathrm{~km}$ away. These are farther away than Flattops, so there should be no additional impact, provided there are no other significant sources nearby. However, these two national monuments should he addressed in future development plans.

Dispersion modeling is necessary to show compliance with allowable PSD ambient increments, and EPA has guidelines on model choice. The 1985 RDDP used VALLEY, a screening model for "complex" terrain. However, complex terrain is defined in the EPA guideline as terrain higher than the release height. Receptors below release height should also be evaluated with otiner models for "simple" terrain. Many areas off-tract are lower in elevation. Other simple terrain models, such as ISC (Industrial Source Complex), should be used and the results further discussed.

PSD ambient increments currently are fully implemented for $\mathrm{SO}_{2}$ and TSP (total suspended particulates) only. However, a $\mathrm{PM}_{10}$ increment is soon scheduled to replace the TSP values (Environment Reporter 5/4/90), and $\mathrm{NO}_{\mathrm{x}}$ increments have been promulgated and will be fully implemented late this year. Since the $\mathrm{C}-\mathrm{b}$ site will be an $\mathrm{NO}_{\star}$ emitter, there could be some futire implications. 
The 1985 RDDP lists a number of chemicals and de minimus emission rates at which the PSD review process is triggered. The original list (FR 52709, Aug. 7, 1980) agrees with the RDDP list. However, the de minimus rates included NESHAP-regulated chemicals which has been expanded to include a few others, especially inorganic arsenic. Arsenic was listed as a potential concern in the EPA Environmental Assessment, January 1981. BACT control technology may need to be applied for arsenic. This should be addressed and if necessary included in new development plans.

Air toxics is an area of debate with the Clean Air Act amendments currently in Congress and is listed as a possible trouble spot for oil shale in a US DOE report (1980), depending on stringency. Colorado is also pursuing development of comprehensive air toxics regulations. Current Colorado regulations (Regulation 3) state that "any" release of a chemical included in a list of over 200 chemicals will trigger a review. Arsenic and arsenic compounds are on the list, and further investigation of toxics may be warranted. The 1985 RDDP plan for following the suggestions of the old Synthetic Fuels Corporation guidelines for monitoring certain non-regulated pollutants may need to be expanded for meeting future toxics regulations. The House and Senate versions of the upcoming Clean Air Act amendments differ in treating air toxics. Both apply "Maximum Available Control Technology" (MACT) for approximately 190 chemicals for major sources greater than 100) tons/year per chemical (250 combined), but the Senate version calls for reducing the residual risk after MACT controls based on health risk assessment (e.g. carcinogenicity). Pilot plant tests at both Pyropower Corporation and Tampella-Keeler, using various blends of oil shale and coal, indicate that air toxics per the 1990 federal Clean Air Act fall below de minimus levels.

Other possible Clean Air Act amendment articles deal with acid deposition, global climate change, and stratospheric ozone destruction. The current acid deposition measures in the Senate version appear to apply only to electric utilities, but the House version includes DOE facilities also (Environment Reporter 7-27-90 has a good summary of all current House and Senate Clean Air Act revisions). The first phase of reductions limits emissions to 2.5 pounds of $\mathrm{SO}_{2}$ per million Btu produced. Since the $\mathrm{C}-\mathrm{b}$ site will become an electricity producer from the CFBC, the acid deposition provisions could affect OOSI. The site could possibly fall into exemption categories due to the unique nature of this facility and to the need for increased domestic oil production. For global climate change, the OOSI proposal appears to have a workable plan for capturing and marketing carbon dioxide should such emissions become regulated in the future. However, carbon dioxide is not explicitly addressed in the current Clean Air Act amendments. The C-b site should not be a significant emitter of chlorofluorocarbons, reported to be responsible for damaging the ozone layer.

Visibility impairment at a Class I national park or wilderness area is regulated in the PSD requirements. The 1985 RDDP discusses use of the recommended EPA modeling techniques, and the $\mathrm{C}$ - $\mathrm{b}$ site passed the first screening tests. The analysis will have to be redone considering the CFBC addition. The state of Colorado is currently pursuing visibility regulations, which may need further investigation.

The distribution of sources used in modeling appears to be adequate, including fugitive dust from area sources. 
The effect of air quality on water quality, soil, vegetation, and wildlife required by the PSD regulations appear to be adequately discussed in the 1985 RDDP.

PSD regulations require monitoring for one year before and one year after construction to confirm compliance with PSD increments. The plan for equipment and locations in the 1985 RDDP appears acceptable. The site-specific dispersion model developed by Aeroenvironment for deterrnining locations of maximum concentration is an appropriate method. $\mathrm{PM}_{10}$ samplers will have to be added since the NAAQS particulate standards were changed from TSP to $\mathrm{PM}_{10}$, as previously discussed.

New Source Performance Standards (NSPS) have been promulgated for particulates from nonmetallic mineral processing including oil shale by EPA and for $\mathrm{SO}_{2}$ emissions from oil shale MIS facilities by the state of Colorado. An exemption to allow $0.3 \mathrm{lbs} \mathrm{SO}_{2} /$ barrel of expected peak production rather than actual production is stated in the Colorado Regulation 3 as described in the 1985 RDDP. The planned facilities in the RDDP appear to meet the NSPS. A review of the new CFBC stacks will have to be included in the analysis.

\section{IMPLICATIONS FOR OIL SHALE ENVIRONMENTAL POLICY}

The permitting process required by the Colorado Department of Health and the US EPA and associated emission controls, should allow the OOSI project to begin without undue environmental impact on air quality. The national ambient air quality standards (NAAQS) should be met, and significant deterioration of air quality and related values such as visibility should be prevented, following current PSD (Prevention of Significant Deterioration) requirements. If the current permitting process fails to show the above compliance, further emission controls will be necessary.

Current and future state and federal regulations of trace toxics, such as arsenic, could pose problems depending on the emissions from the proposed CFBC stacks and on the stringency of the future regulations, especially allowable residual risk following controls. Acid deposition provisions in the new Clean Air Act amendments may affect the site.

Upcoming new PSD allowable increments for nitrogen oxides and $\mathrm{PM}_{10}$ should be addressed in the future. Possible new Colorado regulations on air toxics and visibility should be watched.

\section{KEY UNRESOLVED ISSUES}

A few points are raised in this report which may need further discussion or investigation:

a. possible inclusion of Dinosaur and Colorado National Monuments as Class I areas for $\mathrm{SO}_{2}$ only, according to Colorado Regulation 3, 
b. use of simple terrain dispersion models rather than the VALLEY dispersion model for receptors with elevations below release height,

c. possible inclusion of arsenic in de minimus emission levels for PSD, and

d. examination of possible arsenic or other toxic emissions covered by the Colorado toxic chemical list.

Other unresolved issues deal with future regulations that are likely to be established or made effective soon, including $\mathrm{PM}_{10}$ and $\mathrm{NO}_{\mathrm{x}} \mathrm{PSD}$ increments, revised state and federal air toxics and visibility regulations, and acid deposition restrictions. These issues can only be addressed after promulgation of the future regulations.

\section{RECOMMENDATIONS}

The current unresolved issues listed above should be discussed with those involved in the air permitting process. The current permitting process and investigation of CFBC emissions should obviously be continued, but based on the 1985 RDDP, the permitting process is essentially on-track. The parties involved in the current permitting should keep a close eye on upcoming new regulations as they are promulgated, especially new PSD increments, acid deposition, air toxics and visibility regulations. 


\section{APPENDIX IIa}

1. Topic Area: WATER

2. Subtopic: Groundwater

3. Review Team Leader: O. James Taylor, Englewood, Colorado

\section{ABSTRACT}

Field data and hydrologic analyses suggest that additional pumping for mine drainage for the proposed project may not affect the flow of Piceance Creek, but uncertainties remain concerning the hydraulic connections among the creek, alluvial aquifer, and bedrock aquifers. Collection of hydrologic data needs to continue, and these data should be analyzed for trends during the project. In addition, a local study of the hydrologic characteristics of the valley fill alluvium is recommended.

After the proposed retorts are burned, they need to be flushed repeatedly with water to stop combustion, cool the retorts, flush sediment, and dissolve expected organic and inorganic materials from the retorts. The flushing needs to continue until measurements of the quality of the water used for flushing indicate that the retorts will not contaminate invading ground water.

Upon abandonment, groundwater will resaturate the retorts and reestablish the natural flow system. Few problems are expected with groundwater contamination in abandoned retorts, if the retorts are thoroughly flushed prior to flooding. However, water quality monitoring is needed within the retorts, and in observation wells nearby to ensure that groundwater contamination is not occurring.

No problems are expected with groundwater migration through abandoned shafts. In a previous study of the impacts of water flooding at the Tract C-b shafts, the author estimated that vertical flow will be negligible in the abandoned shafts after water flooding.

After the retorts are abandoned, the retorts could become a valuable large capacity storage reservoir, that would be valuable in water management in the Piceance Creek valley.

\section{SUMMARY OF FINDINGS TO DATE}

\section{History of groundwater studies}

The proposed modified in-situ demonstration plant at Tract C-b lies in the northern part of the Piceance structural basin, and within the Piceance Creek drainage basin. A general understanding of the regional groundwater flow system has develoned through investigations made by the various government agencies, oil shale development companies, and private consultants. This understanding is based on the compilation and analysis of field data that were collected during exploratory drilling 
and mining activities. Data collection began early in the 1900's and has continued to the present time.

In addition, computer model studies of the groundwater flow system made by the U.S. Geological Survey, oil shale companies, and consulting engineering companies added to the understanding of groundwater conditions. These computer studies include the simulation of natural groundwater flow conditions, and the simulation of the effects of mine drainage on the regional groundwater flow system.

The current computer model of Piceance basin is an advanced three dimensional version that simulates all streams, springs, and aquifers (Taylor, 1986). This model was prepared jointly by the U.S. Geological Survey and a group of oil shale companies.

\section{Groundwater occurrence}

The groundwater occurs within two major types of aquifers, bedrock and unconsolidated alluvial aquifers, in the region of the proposed demonstration plant.

The bedrock aquifer system occurs within the fractured oil shale beds of the Parachute Creek Member of the upper part of the Green River Formation and the sandstone beds of the Uinta Formation. The average total thickness of the bedrock aquifers basinwide is about 1,750 feet. The Garden Gulch Member of the Green River Formation underlies the fractured oil shale aquifers; it has a low permeability and forms a lower boundary for the groundwater that occurs in the oil shale and sandstone aquifers above. Most of the oil shale resource and the proposed in-situ retorts occur within the bedrock aquifer system.

Groundwater occurs in naturally occurring fractures in the bedrock aquifers. These fractures transmit groundwater more readily in the horizontal direction than in the vertical direction, resulting in a lower vertical permeability for the bedrock aquifers compared to the permeability in the horizontal direction. In addition, directional horizontal permeability has been detected in the oil shale aquifers directly above the Mahogany zone; this anisotropy of horizontal permeability affects the drawdown pattern that will develop from pumping for mine drainage, especially during the early stages of any pumping activities. Groundwater in the bedrock aquifers occurs under confined conditions. The confined conditions result from numerous layers of low permeability that occur within the oil shale and sandstone, and alternate with permeable zones.

Groundwater quality is extremely variable over the extent and depth of Piceance basin. The natural quality of groundwater occurring in the oil shale aquifers near Tract $C$ - $b$ has been discussed by Leenheer and Noyes (1986). Water pumped from the oil shale beneath Tract C-a was analyzed for inorganic constituents and dissolved organic carbon in 1981. (Tract $\mathrm{C}-\mathrm{a}$ is about 15 miles to the northwest from Tract C-b.) The dissolved solids concentration at Tract $C$-a was about 1,400 mg/1 and the water was slightly alkaline. Prominent cations were sodium, magnesium, and calcium; prominent anions were bicarbonate and sulfate. Dissolved organic carbon was less than $5 \mathrm{mg} / \mathrm{l}$ in all samples. 
The unconsolidated valley fill alluvial aquifer occurs in the valley of Piceance Creek. It consists of intermixed deposits of gravel, sand, and clay. Near the proposed demonstration plant at Tract C-b, the alluvium attains a maximum thickness of about $100 \mathrm{feet}$, and the saturated thickness averages about 70 feet. The groundwater in the alluvial aquifer flows through several compartments in the alluvium, separated by various layers of clay that tend to isolate these compartments hydraulically. Groundwater in the alluvial aquifer occurs under unconfined and confined conditions.

\section{Groundwater recharge, movement, and discharge}

Natural recharge to the bedrock aquifers results from precipitation within the Piceance Creek drainage basin. Groundwater occurring at Tract C-b was recharged south of the tract, near the headwaters of the tributaries to Piceance Creek known as Stewart Gulch and Willow Creek. Water from snowmelt and rainfall infiltrates the bedrock aquifers and recharges them in these regions. These land regions are at higher altitudes than the Piceance Creek valley, and receive more precipitation compared to lower areas.

The recharged water moves very slowly toward the Piceance Creek valley, by circulating through the thick sequence of fractured shale and sandstone. Groundwater in the bedrock aquifers discharges as springs in the creek valley, or into the alluvial sand and gravel deposits. Although Willow Creek and Steward Gulch are perennial streams that cross Tract C-b, it is unlikely that the bedrock aquifers discharge to these tributaries.

The groundwater flow system of the alluvial valley fill aquifer is shallow and localized in contrast to the bedrock aquifer system. It is recharged by precipitation on the valley floor, by leakage from the bedrock aquifers, and by leakage from Piceance Creek. In addition, irrigation water diverted from Piceance Creek is spread on the valley floor and recharges the alluvial aquifer during the irrigation season. Groundwater in the alluvial aquifer moves toward the north as underflow and probably discharges into the alluvium of the White River at the mouth of Piceance Creek. Groundwater in the alluvial aquifer also discharges to Piceance Creek. The evidence that the alluvial aquifer exchanges water with Piceance Creek comes from gain and loss studies. Near Tract C-b, in some reaches of the valley, Piceance Creek recharges the alluvial aquifer; in other adjacent reaches the alluvial aquifer discharges to Piceance Creek.

\section{Historical mine drainage}

Mine drainage activities at Tract C-b began in 1979 and continue to the present. At times some of water pumped from the mines was reinjected into the oil shale aquifers using injection wells on the tract, but distant from the shafts. The net withdrawal rate from the mines initially was more than $1 \mathrm{ft}^{3} / \mathrm{sec}$; currently the net withdrawal rate is about $0.6 \mathrm{ft}^{3} / \mathrm{sec}$. For comparison, the average flow at the mouth of Piceance Creek is about $24 \mathrm{ft}^{3} / \mathrm{sec}$.

Mine drainage activities have dewatered the oil shale aquifers near the pumping sites and intercepted groundwater that formerly discharged into the Piceance Creek valley. However, most of the pumped water has been treated and then discharged into Piceance Creek. The effect on the flow of Piceance Creek has been an increase in flow, because: 
Part of the water discharged to the creek represents water taken from storage in the oil shale aquifers that could not have discharged to the creek so rapidly under natural conditions.

It is not certain that all of the water intercepted by the pumps would have discharged into the creek; the pumped water might have discharged into the alluvial aquifer, flowed as underflow in the downstream direction, and into the White River valley. However, presumably this intercepted water would have discharged into the stream system eventually.

Part of the mine drainage water also has been used in sprinkler irrigation on nearby land areas.

\section{Environmental groundwater data}

Groundwater data are more abundant at Tract C-b than at any other site in Piceance basin, because environmental monitoring was conducted in conjunction with mine drainage and planned oil shale development. Currently the discharges of 17 nearby springs are monitored monthly. In addition, water levels are measured monthly in 57 wells completed in the fractured oil shale aquifers, and 15 wells completed in the alluvium. Measurements are also made in 25 wells distant from Tract $\mathrm{C}$-b that are completed in the oil shale aquifers; these additional measurements are required in the augmentation plan under Colorado law, to ensure that operations at Tract C-b do not affect the water resources at other sites in Piceance basin.

Spring discharges have been monitored since 1986. Although the spring data do not indicate any perceptible decline in discharge at any spring, the length of record is not sufficient to determine trends. Also the springs were not measured prior to the beginning of pumping for mine drainage in 1979.

Hydrographs of wells completed in the oil shale aquifers indicate considerable fluctuations as expected. Large declines in water levels show dewatering of the aquifer as planned; rises in water levels show the effects of injection into wells in the past. The hydrographs are typical for measurements of wells completed in an aquifer from which water is pumped, and into which water is injected.

The hydrographs of wells completed in the alluvium of Piceance Creek show little variation with time. Depths of these wells range from 30 to 112 feet; depths to water ranged from 7.7 to 72.4 feet in 1983; saturated thicknesses in these wells range from 1.0 to $74.3 \mathrm{feet}$. The lack of response of the water levels in the alluvium to pumping for mine drainage probably is due to the discharge of mine water into Piceance Creek after treatment, and the presence of clay beds in the alluvium that tend to isolate the warer into permeable sand and gravel compartments that are poorly connected to the oil shale aquifers. Also the mine drainage pumps are distant from the alluvial aquifer in the Piceance Creek valley.

Hydrographs of closely spaced pairs of wells completed in the bedrock and in the alluvium also indicate a poor degree of hydraulic connection between the bedrock and alluvium. The declines in the bedrock wells in response to pumping are not reflected in the hydrographs of wells completed in the alluvium. 


\section{Environmental water quality data}

After the proposed retorts have been ignited, burned, and quenched, they will be flushed repeatedly to remove fine serliment, flush gases, and dissolve soluble salts and organic material from the retorts. This flushing will reduce the amounts of any toxic chemicals in the retorts after the proposed project is complete.

A summary of the effects of repeated retort flushing on water quality is discussed by Persoff and Fox (1983). Normally after flushing retorted shale in a retort with 3 to 4 pore volumes of water, the concentration of leachate present in the flush water is reduced to about 10 percent of the original concentration present in the leachate from the first flushing. It is obvious that repeated flushing of burned retorts dramatically reduces the soluble material in the retort.

The experiences of Occidental Oil Shale Inc. on retort flushing at Logan Wash near De Beque, Colorado are described by J. E. Boysen, J.R. Covell, K. G. Kofford, J. E. Marshall, and R. G. Vawter (1990). Modified in-situ retorts were burned and monitored at Logan Wash to test the process and its environmental impacts. Company data on retort flushing with process water were analyzed for water quality from 1979 to 1989 . Substantial reduction of dissolved organic carbon was noted, from a maximum of about $875 \mathrm{mg} / \mathrm{l}$ to a minimum of about $50 \mathrm{mg} / \mathrm{l}$ in about 2,600 days. The water supply at Logan Wash is meager; it is likely that dissolved organic carbon in the flushing water would have been reduced even more rapidly if larger volumes of water for flushing had been available.

The historical effects of modified in-situ retorting on groundwater quality also have been discussed by Leenheer and Noyes (1986). In 1981 and 1982 a modified in-situ retort was burned at Tract $\mathrm{C}$-a and water quality samples were collected and analyzed. Because of pump failure during retort burning, the retort was partly backflooded. Therefore it was possible to compare groundwater quality before and after retort burning, although the invaded groundwater at Tract $\mathrm{C}$-a did not react with the retort as thoroughly as did the flushed water at Logan Wash described above. The comparisons were made for inorganic and organic constituents.

At Tract $\mathrm{C}$-a the inorganic constituents that increased above natural levels included calcium, ammonium, and sodium. Thiocyanate was present in the water that backflooded the retort, even though it was not detected in the groundwater prior to retort burning. Thiocyanate is a conservative solute tracer that is useful in detecting retort wastewater in groundwater.

Detailed analyses were made of the organic constituents that increased at Tract C-a in the backflooded water. The concentration of dissolved organic compounds increased from less than 5 $\mathrm{mg} / \mathrm{l}$ in natural groundwater to about $26 \mathrm{mg} / \mathrm{l}$ in the backflooded water. Numerous organic compounds were found, but their concentrations; are not repeated here; they were classified into the following groups of dissolved organic compounds:

Hydrophobic bases Hydrophobic acids Hydrophobic neutrals
Hydrophilic bases

Hydrophilic acids

Hydrophilic neutrals 
The hydrophobic organic waste constituents tend to be sorbed on aquifer sedimentary material, sediments in surface water, and on soils; the hydrophilic organic waste constituents are more soluble and likely are transported as solutes. However, these hydrophilic solutes are biodegradable. Therefore both types of dissolved organic constituents either tend to be trapped, or degraded to harmless materials.

The effects of repeated retort flushing on organic constituents also are discussed by Leenheer and Noyes (1986). In general the hydrophilic organic constituents are easily removed in flushing and can be removed by treatment. The hydrophobic organic constituents are not easily removed by flushing. The most troublesome hydrophobic organic constituents mentioned by Leenheer and Noyes (1986) are aromatic amines. As they persist in sorbed states on retorted shale or sediments, they may cause long term odor problems.

Preliminary data from an in-situ retorting site near Rock Springs, Wyoming provide additional information. J.A. Leenheer (U. S. Geological Survey, oral communication, 1990) suggests that the kerogen occurring in the oil shale may be a good material for sorbing the aromatic amines, eliminating or reducing the odor problem. Therefore any aromatic amines that migrate from abandoned retorts and into the undisturbed oil shale aquifers, likely will be sorbed in the aquifers where they will not cause environmental problems. Also control technology is fully able to provide sorbents that will eliminate the odor problem, if it occurs.

The Rock Springs site was a horizontally-developed fractured bed which underwent only partial combustion, leaving significant hydrocarbons after passage of the flame front. Data from the Rock Springs site suggest that ketones and phenols may migrate from the retorts, if they are flooded. However, it is likely that ketones and phenols will not migrate from retorts in which combustion is complete.

When the retorts are flooded after project abandonment, they will fill slowly because of low permeability of the surrounding oil shale aquifers, and the relatively high porosity of the retorted zones. The relatively large volume of groundwater that invades the abandoned retorts would dilute any remaining soluble material greatly. Thus an inherent property of the abandoned retorts would help to diminish any risk of unacceptable concentrations of soluble material in the burned retorts.

\section{Planned development}

The current plans for development consist of additional in-situ retorts expanded toward the southwest from the main shaft. This expansion will entail additional mine drainage before the retorts can be mined, rubblized, burned, cooled, and flushed over a ten year period.

Additional pumping will be used to accomplish the required mine drainage. The effects of additional pumping will be similar to the historical pumping: removal of water from storage in the oil shale aquifers and interception of groundwater that formerly discharged into Piceance Creek valley. However, some differences are likely, as described below. 
The area of planned mine drainage is in the upgradient direction, along the stream lines of the flow system and toward the natural recharge areas. Therefore it is likely that little of the additional pumped water will be derived from additional interception of groundwater formerly discharged into Piceance Creek valley. Part of the groundwater flowing across Tract C-b has already been intercepted by historical pumping; additional pumping likely will be derived from storage in the oil shale aquifers, and not from additional interception of groundwater flowing toward Piceance Creek valley.

In addition, mine drainage pumps will withdraw water from sites that are more distant from Piceance Creek than current and historical pumps. Therefore the effect of pumpage on the water resources (groundwater and surface water) of Piceance Creek valley will be reduced and delayed in time.

As the project proceeds, progressively more of the water drained from the mines will be needed for processing in plant operations. Therefore the amount of mine drainage water available for treatment and discharge into Piceance Creek will diminish as the project proceeds. Because of the reduction of water discharged to the creek, the creek flow will be augmented by progressively less mine drainage water than it has been since mine drainage activities began.

If the mine pumping should deplete the flow of Piceance Creek, a state approved augmentation plan will be used to replace any reduction in flow. This plan utilizes various sources of water from streams, wells, and storage for replacement.

After the retorts are completely burned, they will be flushed with water to stop the burning, cool the retorted shale, remove gases, and remove soluble and suspended material from the retorts. This flushing action will be continued until most of the soluble and suspended material has been removed from the retorts. The water used for cooling and flushing will not be discharged into the river.

When the project is abandoned, it is likely that the pumps will be shut off and the mines will be flooded. A study was made by Taylor (1988) to determine the effects of mine flooding in relation to groundwater movement through the abandoned shafts. The study concluded that even though aquifers above and below the Mahogany zone would be connected through the abandoned shafts, the natural groundwater flow thiough the shafts would be small and insignificant due to the small differences in hydraulic head.

The MIS retorts will be regulated under the Underground Injection Control Section of the Safe Drinking Water Act passed in 1974. They will be under Class V, In-situ Fossil Fuel Recovery Wells. Environmental concerns relate to the contamination of current drinking water supplies, and supplies that may become drinking water sources in the future. Shallow drinking water supplies are of particular concern.

Because of the hydrologic and chemical characteristics of the abandoned retorts, it unlikely that serious environmental problems will develop. These characteristics are summarized below: 
Appendix Ila - Groundwater

a. Stagnation zones (zones of zero velocity) will not develop near the retorts because of configuration of the local and regional flow systems. Therefore any contaminants that are produced will not be isolated from pumping, flooding, and flushing activities.

b. Because of the characteristics of the flow system, any contaminants that result will not be isolated hydrodynamically from the flow system at any time. Therefore any such contaminants will be identified during the project life; they will not appear later after monitoring has ceased.

c. Fine sediment will not be present in the abandoned retorts; it will be removed during the repeated flushing activities. Therefore contaminants cannot be diffused into, or sorbed onto fine sediments and later diffused or desorbed into coarse permeable zones in the flow system.

d. Aside from MIS retorts, few groundwater contamination sites offer the opportunity to flush contaminants repeatedly under alternating saturated and unsaturated conditions. Therefore the retorts will be easy to clean and monitor, compared to most contaminated groundwater sites.

e. The retort flushing under high temperature conditions will facilitate the removal of soluble and volatile constituents.

f. Flooding by relatively large volumes of groundwater will tend to remove any soluble constituents rapidly.

The 17 abandoned retorts will have hydraulic properties that are very different from the properties of the bedrock prior to development. For example, the effective porosity of the retorts will be much higher than that of the fractured oil shale under natural conditions. Also the permeability will be substantially increased in all directions. The enhanced porosity and permeability result from the combined processes of mining, rubblization, ignition, and flushing.

Because of the enhanced porosity and permeability, the abandoned retort zones will become enhanced aquifer zones that could be used in water management. After resaturation, these zones will contain at least 1,000 acre feet of groundwater in storage, probably 5 times more than the undisturbed oil shale contained in storage. This water could be easily withdrawn and used to supplement the flow of Piceance Creek during drought periods. Alternatively, during periods of above normal precipitation and surface runoff, excess water could be rapidly recharged into the zones of enhanced hydraulic properties. The use of the abandoned retort zones as an underground reservoir would add considerable flexibility to water management alternatives in Piceance basin and downstream areas. However, this proposed plan would have to be approved in water court before it could be implemented. 


\section{IMPLICATIONS FOR OIL SHALE ENVIRONMENTAL POLICY}

Hydrologic data are abundant for evaluating the environmental impact of the proposed project. Water management plans are sound and well founded.

Hydrologic monitoring that has been conducted in the past needs to be continued to ensure that the system behaves as expected.

The quality of water used to flush the retorts needs to be analyzed continually to determine whether or not toxic materials are present.

When the retorts are abandoned after continual flushing and monitoring, water quality monitoring should be done within the retorts, and should continue in nearby wells, to ensure that the groundwater is not being contaminated. Monitoring within the retorts is necessary to detect any water quality problems early, so that proper action can be taken, if needed.

After the burned retorts are abandoned and flooded, they likely can be used as an underground water storage reservoir that could improve water management in the Piceance basin.

\section{KEY UNRESOLVED ISSUES}

The key unresolved water issues relate to the impact of mine drainage on the stream system and water quality concerns. One of the objectives of the demonstration project is to monitor the streamflow and the water quality during actual development. Only then will the true impacts of development on the water resources be known.

Although regional hydrologic information indicates that the bedrock aquifers discharge to Piceance Creek valley, the geologic and hydrologic conditions throughout Piceance Basin are site specific. For example, gain and loss studies made on Piceance Creek and described by Taylor (1987, p 74) indicate that some reaches of the creek gain flow from the alluvial aquifer, yet adjacent reaches lose surface water to the alluvial aquifer. Therefore the bedrock aquifers may, or may not discharge to Piceance Creek at Tract C-b.

The alluvial valley fill aquifer along Piceance Creek contains clay layers that impede vertical movement of groundwater and impair the hydraulic connection between the bedrock aquifers and the stream. Therefore the true impact of mine drainage on the flow of Piceance Creek is not known. A local study of the hydrologic characteristics of the valley fill aquifer would improve the level of understanding of the degree of hydraulic connection between the bedrock aquifers and the stream.

Fortunately, if the flow of Piceance Creek is reduced, a plan of augmentation is in place. Water depleted from the creek can be replaced with water withdrawn from other wells, streams, the White River, or water purchased from others. 


\section{Appendix Ila - Groundwater}

When the burned retorts are abandoned and flooded, the water quality of the invaded water within and near the retorts should be monitored. It is possible that poorly soluble contaminants not flushed previously may go slowly into solution in the local groundwater.

A solute transport model could be used to estimate the migration of any solute. This type of model could be prepared by slight adaptations to the hydraulic model prepared by Taylor (1986).

\section{RECOMMENDATIONS}

The historical field data describing streamflow, spring flow, and water levels in wells need to be analyzed throughout the project to clarify the true hydrologic effects of mine drainage. The following analyses are suggested:

- Data describing monthly streamflow of Piceance Creek, at a gage downstream from Tract C$b$, should be correlated with data from a gage upstream from the tract. If a change in the flow of Piceance Creek occurs, this change should be indicated by the correlation. Gages selected need to be located:

1. Beyond the possible zone of groundwater impact on the stream, and

2. Near Tract C-b so as to reduce the effects of surface runoff to the creek and any surface diversions from the creek between the gages used for the correlation.

D Data describing the monthly flows of individual springs should be plotted on single mass diagrams using the historical data and data collected throughout the development period. If the flow of any spring declines because of mine drainage, the change will be indicated by a change in the slope of the single mass diagrams.

- Water levels in welis completed in the alluvial aquifers should be analyzed for any trends related to mine drainage of the bedrock aquifers. If water levels in these wells do not decline, it is inlikely that mine drainage has affected the flow of Piceance Creek.

- A local hydrologic investigation is needed for the valley fill alluvial aquifer near Tract C-b. Clay layers in the aquifer should be located from drillers' logs, or from gamma ray logs in the wells completed in the alluvium. The hydrologic behavior of groundwater in various compartments in the alluvial aquifer should be studied, using existing wells and historical data. This investigation would help to clarify the degree of hydraulic connection among Piceance Creek, the alluvial aquifer, and the bedrock aquifers.

- Water used to flush the retorts needs to be analyzed continually for organic and inorganic constituents, in order to predict any possible water quality problems, and to design controls on such problems before they occur. 
- When the retorts are abandoned and flooded, the water quality of the invaded and surrounding groundwater should be monitored until it is clear that water quality problems are not likely to develop. Thiocyanate, phenols, and ketones should be analyzed in the retorts, and in observation wells completed in the oil shale aquifers and located in the vicinity of the retorts.

\section{REFERENCES}

Leenheer, J.A., and Noyes, T.I., 1986, Effects of or"vanic wastes on water quality from processing of oil shale from the Green River Formation, Culorado, Utah, and Wyoming: U.S.Geological Survey Professional Paper 1338, 56 p.

Persoff, P., and Fox, J.P., 1983, Evaluation of control technology for modified in-situ oil shale retorts in Sixteenth Oil Shale Symposium Proceedings, Dr. James H. Gary, editor, pp 534-540.

Taylor, O. J., 1980ó, Simulation of mine drainage for preliminary development of oil shale and associated minerals, Piceance basin, northwestern Colorado: U.S. Geological Survey WaterResources Investigations Report 86-4011, 25 p.

Taylor, O.J., 1987, Oil shale, water rescurces, and valuable minerals of the Piceance basin, Colorado: the challenge and the choices of development: U.S. Geological Survey Professional Paper $1310,143 \mathrm{p}$.

Taylor, O. J., 1988, Predicted effects of underground mine flooding at Tract C-b in Piceance basin, northwestern Colorado: U.S. Geological Survey Water-Resources Investigations Report 87$4189,16 \mathrm{p}$.

Boysen, J.E., Covell, J.R., Kofford, K.G., Marshall, J.E., and Vawter, R.G., 1990, Management program for spent modified in-situ retorts: in Twenty Third Oil Shale Symposium Proceedings, Dr. James H. Gary, editor, in press. 


\section{APPENDIX IIb}

1. Topic Area: WATER

2. Subtopic: $\quad$ Surface Water

3. Review Team Leader: C. R. Jenkins, Professor

Civil Engineering Department

West Virginia University

\section{ABSTRACT}

A preliminary water budget, relative to the proposed MIS process with associated CFBC power plant has been prepared by OOSI. It indicates the principal water streams required by and produced by various components of the system: mine dewatering, bulkhead water collection, processing, boiler feed, boiler blowdown and cooling systems.

The quality of water emanating from quenched retorts is of particular interest. It is likely that it will be saline and alkaline. The total organic content has been shown to decline over time for similar retorts at Logan Wash. Total dissolved solids in water used to flush the retorts has so far remained high. A definition of what constitutes a satisfactorily reclaimed spent retort has not been finalized. There are no plans to discharge process water to receiving streams and indeed, the NPDES discharge pormit prohibits any discharge other than treated mine water. All excess water is to be evaporated, either through quenching of retorts, by spraying on the boiler ash pile or in an evaporation pond. Process water streams which contain significant organic compounds will be incinerated in the CFBC.

The lease stipulations and the NPDES discharge permit call for strict control of surface discharge and the resultant protection of Piceance Creek. Based on the information that is available no unsolvable problems regarding surface water protection have been detected.

\section{SUMMARY OF FINDINGS TO DATE}

On April 9-11, the C-b site was visited and literature in the EMRx library was surveyed. A large amount of information regarding water issues related to oil shale projects was collected from the library and has been reviewed. The "Revised Detailed Development Plan" by Cathedral Bluffs Shale Oil Co. (CBSOC) contains a detailed presentation oi anticipated water balances and projections of water quality (4). The more currently pertinent "Development of a Comprehensive Plan and Justification for a Proof-of-Concept Oil Shale Facility" does not focus on water issues (18). The more recent "Demonstration Project Assessment Report Proof-of-Concept Oil Shale Facility, Colorado Tract $C$ - $b$ " presents a more detailed water management plan but does not include a detailed water balance (17). Bechtel has submitted a draft of a water management document which includes a Management Plan, block Flow Diagram and a Steady State Summer Water Balance Spreadsheet. This information provides a defined construct of anticipated water supply needs and final disposal (16). Material collected from the library includes considerable data resulting from various 
background studies. Some articles predate MIS technology. These are lengthy articles by the EPA, and the Department of Interior regarding treatment process evaluation and general environmental impact analyses. The Oil Shale Lease Environmental Stipulations which OOSI proposes to use as a guide in developing new management plans is comprehensive regarding water use, waste disposal, impoundment and spill control (19). The NPDES permit issued by the State of Colorado will expire in 1993. It defines stream standards for Piceance Creek and sets discharge limits for mine dewatering, settling ponds and the sewage treatment plant. The permit specifies that no discharge of treated or untreated process wastewater shall occur (13). Comments on topics pertinent to surface water are:

\section{a. Usage/Availability}

A series of reports covering anticipated environmental impacts of oil shale development was prepared in the 1970's and early 1980's (1), (6), (7), (8), (9), (10), (11), (2), (14). These reports commonly predict that for in-situ retorting a surplus of water will exist during the early development of the site but a deficiency is predicted for later stages. Development using the MIS process is expected to require less than half the water necessary for alternative methods of site development (7). It is anticipated that mine dewatering will provide an adequate flow for this project and in addition some surface water rights are owned by OOSI. A flow diagram showing all water sources, uses, and wastewater production has been developed. The Bechtel plan calls for extensive reuse of water throughout the system. Primarily there are three types of water produced on the site: (1) process water recovered from the MIS offgas quench tower (2) bulkhead water collected at the bulkheads and separated from bulkhead oil in the underground separator or the offgas line boot, (3) mine water aquifer dewatering adjacent to underground facilities (16).

\section{b. Process/Mine Water Disposal/Reuse}

Only water from mine dewatering operations would be released into Piceance Creek. A persistent concern for the presence of dissolved solids and the potential to increase TDS in Piceance Creek commonly shows up in environmental impact studies (8), (9), (3). Of special concern is fluoride. It would appear that if fluoride levels are set at $4 \mathrm{mg} / \mathrm{L}$ in the receiving stream difficulty in meeting permit requirements may be experienced.

The recently proposed "Demonstration Project Assessment Report" indicates that excess quench water and retort leaching water would be disposed of hy evaporation ponds (27). High TDS wastewater from units treating cooling and boiler feed water will be sprayed on boiler ash piles. The water will evaporate leaving the solids behind in the pile (6), (16). Evaporative concentration processes have the potential for the solids to be remobilized as a result of weathering. Proper management of refuse piles and evaporation ponds will protect surface and groundwater from the effects of long term leaching. Negative impacts of evaporation ponds that might occur are discussed in the Environmental Statement for the Prototype Oil Shale Leasing Program (7). The Bechtel report discusses mine abandonment and the flushing of retorts to ensure removal of residual organic compounds. This wastewater will go to the sour water stripper, the wastewater treater and CFBC. While this system should remove organic contaminants the rate of salt retention in the retort water remains to be defined (16). Other literature suggests that the retorts may accumulate high inorganic 
Appendix IIb - Surface Walcr

TDS water (5). If leaching inorganics from the retorts is required, more extensive evaporation ponds may be required.

\section{c. Runoff/Impoundment}

Most states have recently adopted non-point source control programs in response to EPA requirements. Evaporative ponds will require linings and monitoring systems. Runoff control from boiler ash piles is covered in detail in the "Revised Detailed Development Plan." (4) Similar consideration for this project should be anticipated and is reflected in the Bechtel report (16).

Waterborne pollutants having potential health effects may be present in the runoff of boiler ash piles. Sodium, fluoride, mercury and selenium have been identified as potential problems (15). The present NPDES permit does not identify any discharge from a spent shale site (13). Runoff can be controlled using conventional revegetacion and impoundment techniques. Westem Research Institute recently tested boiler fly and bottom ashes for extractable organics and inorganics. RCRA metals did not exceed regulatory limits. The only organics identified in the extracts are not regulated (20).

Sludge from the wastewater treatment system will be burned in the CFBC. Water in the sludge will evaporate, organics will burn and the inorganics will be incorporated into the ash. High TDS wastewater will be sprayed onto ash piles. As the water evaporates from the piles solids will precipitate and become incorporated in the ash (16). Limits have been set for discharge from erosion control ponds. So far none of these ponds have produced a discharge (13).

\section{d. Spill Prevention}

Control and mitigation of spills was covered in some detail in the Revised Detailed Development Plan (RDDP). The NPDES permit required that an update of the containment plan be submitted (13). The spill prevention, control and countermeasure plan was submitted in February 1990 and applies to the present level of activity at the C-b site (12). Addressing the requirements of the lease stipulations and specifications of the Colorado Department of Health should provide adequate spill control (19).

\section{IMPLICATIONS FOR OIL SHALE ENVIRONMENTAL POLICY}

Policies needing to be addressed will be stipulated by the State of Colorado regulatory bodies. Accountability of quantities of water withdrawn, used and discharged will require attention. Concentration of dissolved solids and fluoride ion in discharged mine dewatering will likely be the major water quality concerns. 
Evaporation ponds used for disposal of process water must be sited, designed and constructed with proper consideration of long term affects. Otherwise, residuals allowed to accumulate in the ponds could be released periodically due to snow melt and rainfall. Process waters may also be disposed of by spraying over ash and shale piles. It must be recognized that the residuals removed by this practice will change the character of the ash or shale piles. Consequently the nature of leachate produced by these piles will be different from that produced by raw ash or shale. A monitoring program will need to be established to evaluate these concerns.

\section{KEY UNRESOLVED ISSUES}

The retort quenching program proposed by OOSI has been demonstrated to effectively reduce the organic content of process water. There does not seem to be a definition as to what constitutes a satisfactorily leached retort. Authorities from regulatory agencies and OOSI should develop an agreement stipulating the character of water to be allowed to accumulate in spent retorts.

\section{RECOMMENDATIONS}

- Finalize a flow design and mass balance showing all water and wastewater flows applicable to the proposed development plan.

- Define what constitutes a cleaned spent retort.

- Conduct a leachate study of ash and shale or other solid substrates used for the disposal of process water.

- Permits will need to be revised to accommodate proposal development.

\section{REFERENCES}

1. Bureau of Land Management, Draft Environmental Impact Statement on the Federal Oil Shale Management Program, Department of Interior, 1984.

2. Bureau of Land Management, Piceance Basin Resource Management Plan and Environmental Impact Statement, U. S. Department of Interior, 1984.

3. C-b Shale Oil Venture, Prototype Oil Shale Leasing Program, Oil Shale Tract C-b Environmental Baseline Program, Final Report Vol. II Hydrology, 1976.

4. Cathredral Bluffs Shale Oil Co., Revised Detailed Development Plan, 1985.

5. Cotter, J. E., D. L. Strehler, R. Sung, S. C. Quinlivan, L. Baboolal, and K. Crawford, 
Environmental Analysis of Oil Shale Operations, Contract \# 68-()2-1881, EPA, 1978.

6. Department of Energy, WY, Environmental Assessment for the Occidental Oil Shale, Inc. Project in response to PON \#2 Garfield County, CO, 1978.

7. Department of Interior, Final Environmental Statement for the Prototype Oil Shale Leasing Program, Vol. I of VI Regional Impacts of Oil Shale Development, 1973.

8. Department of Interior, Final Environmental Statement for the Prototype Oil Shale Leasing Program, Vol. III of VI Regional Impacts of Oil Shale Development, 1973.

9. Department of Interior, Final Environmental Statement for the Prototype Oil Shale Leasing Program, Vol. IV of VI Regional Impacts of Oil Shale Development, 1973.

10. U. S. Department of Interior, In-situ Oil Shale Leasing, Preliminary Draft, 1978.

11. Department of Interior, Final Supplemental Environmental Impact Statement for the Prototype Oil Shale Leasing Program, 1983.

12. EMRx, Spill Prevention, Control, and Countermeasure Plan, State of Colorado.

13. EMRx, NPDES Permit No. CO-0033961, State of Colorado.

14. General Accounting Office, Colorado River Basin Water Problem: How to Reduce Their Impact Report to Congress, 1979.

15. Gratt, L. B., Oil Shale Risk Analysis, Oil Shale the Environmental Challenge II, The Oil Shale Task Force, 1981.

16. Knapp, S., Bechtel Job No. 20277-010.

17. Occidental Oil Shale, Inc., Demonstration Project Assessment Report, Proof-of-Concept Oil Shale Facility Colorado Tract C-b., 1990.

18. Occidental Oil Shale Inc., Development of a Comprehensive Plan and Justification for a Proof-of-Concept Oil Shale Facility (1989).

19. Oil Shale Lease Environmental Stipulation, Federal Government.

20. Western Research Institute, TCLP Extraction Results. 


\section{APPENDIX III}

1. Topic Area: SOLID WASTE

2. Subtopic: $\quad$ N/A

3. Review Team Leader: John J. Bowders, Assistant Professor

Civil Engineering Dept.

West Virginia University

\section{ABSTRACT}

The project will generate two types of solid wastes: boiler ash and oil shale. Oil shale is known to be an innocuous material. Boiler ash is a new material and has only recently been generated and studied.

Boiler ash will be generated from the Circulating Fluidized Bed Combustor (CFBC). It will consist of combusted oil shale and coal. This material will be disposed in surface dumps. The amount of ash to be generated is as yet unknown as coal/oil shale optimization trials are currently underway. The low inherent permeability of CFBC ash will tend to isolate it from precipitation water. A leachability study of the CFBC ash is underway. Preliminary results indicate that no RCRA metals exceed the regulatory limits. The indication from this work is that the ash will not present an environmental threat. Previous studies have shown that the raw rock (non-retorted oil shale) does not present significant pollution threats when disposed in landfills. Field studies regarding the leaching and permeability characteristics of the disposed ash should be considered. It is anticipated that the results of such a study would confirm the laboratory findings regarding the leachate characteristics of the ash.

Specific plans for dealing with disposal of the solid wastes generated from the C-b site are being developed and have yet to be addressed. Preliminary reports indicate that the solid waste derived from the mining of oil shale would be disposed of in a fill located in the valley immediately adjacent to the mine shafts (where material previously mined from the shafts has been placed). It is not currently expected that a surface retort will be operated during the demonstration and there are no specific plans for disposal of retorted shale; however such plans were developed for earlier commercial plant designs.

\section{SUMMARY OF FINDINGS TO DATE}

\section{Introduction}

This review contains evaluation of the disposal considerations for the CFBC Wastes, Process wastes, and mined oil shale. As the Proof-of-Concept project is somewhat different from the production plan, only comments in regard to the Proof-of-Concept project are addressed herein. These findings reported here are based on the following sources of information: 
1. Vol. 1 - Technical Proposal "Development of a Comprehensive Plan and Justification for a Proof-of-Concept Oil Shale Facility Colorado Tract C-b," Occidental Oil Shale, Inc. (Dec. 6, 1989)

2. "Revised Detailed Development Plan," Cathedral Bluffs Shale Oil Company (1985)

3. Site Visit to C-b and Logan Wash Retort Site (April 10-12, 1990)

4. Discussion with various personnel at the retort sites (April 10-12, 1990)

5. Chew, Studebaker and Bender (1975) "Environmental Considerations for a Proposed Mineral Shale Waste Pile in Logan Wash," Dec. 29, 1975, Occidental Oil Shale, Inc.

6. "The Disposal and Environmental Effects of Carbonaceous Solid Wastes from Commercial Oil Shale Operations," 1st Annual Report NSF GI 34282X1, NSF RANN, Wash., DC. Jan. 1974

7. "Management of Solid Waste Residuals from Oil Shale Recovery Processes," US EPA Cincinnati, OH, TRW and Denver Research Institute, May, 1977

8. "Geotechnical Investigation Proposed No Name Gulch Dam," C-b Shale Oil Venture," Dames and Moore, Oct. 24, 1978

9. "Management Program for Spent Modified In-situ Retorts," Pre-print of a paper by Boysen, Covell, Kofford, Marshal, and Vawter, (1990)

10. "Demonstration Project Assessment Report Proof-of-Concept Oil Shale Facility Colorado Tract C-b," June 1990, Occidental Oil Shale, Inc. for US DOE METC, Contract No. DE-AC21-90MC27084

11. "TCLP Extraction Data," from Western Research Institute, June 15, 1990

\section{a. Mined Oil Shale}

The mined oil shale will be stockpiled adjacent to the site. It will be used to co-fire (with coal) a circulating fluidized bed combustion furnace (CFBC). Thus, the raw shale will only be temporarily stored at the surface. Any excess shale will be disposed in the existing disposal area located adjacent to the mine shafts. The in-situ retorting process limits the quantity of raw shale which will be brought to the surface to that mined from the access shafts, drifts, etc. Since this material will be used in the CFBC, its ultimate disposal will not be a significant concern. 


\section{b. CFBC Waste}

Boiler ash will result from the co-combustion of oil shale and perhaps coal. It will require disposal if an alternative use is not developed. Current research at the University of Pittsburgh has indicated that the ash is capable of producing a low-grade cement. Additional testing is underway. Should a utilization for the ash be developed, disposal will be less of an issue since some of the material will be capable of being marketed. However, some disposal facilities will be necessary as markets for all of the ash is not likely.

An initial test burn included 100 tons of shale and 12 tons of coal. The ash resulting from this burn was tested in TCLP Extractions by the WRI. None of the regulated heavy metals exceeded the RCRA limits thus indicating that the disposal of the ash does not present a metal pollution problem (see Table 1). It must be noted that the TCLP test is a severe environment in which the ash is placed in an acidic bath. In this state, metals are readily leached. However, under field conditions, it is more likely that the environment would be alkaline in which case, metals tend to remain insoluble and not leach from the ash.

Also attached (Tables 2a-i) are summaries of analyses of semivolatile compounds extracted from both fly and bottom boiler ash. Only benzoic acid and bis(2-Ethylhexyl)Phthalate appeared in trace amounts. Neither chemical is regulated. Bis(2- Ethylhexyl)Phthalate was also detected in the blank samples so it was probably an artifact. It is used as a plasticizer and may have entered the samples through contact with plastic containers or tubing. It is sometimes found in blood samples due to storage in plastic bags.

Although no specific plans are available, verbal references indicated that the ash will be disposed in a landfill in No Name Gulch immediately adjacent to the mine. This will likely be disposed jointly with excess raw shale rock. The exact quantity of ash to be generated will be a function of the ultimate boiler configuration and shale/coal blend. However, it is expected that the CFBC will burn about 1550 tons of shale per day so the rate of boiler ash production will be somewhat less than this amount. The details of this boiler ash dump design are currently being developed for OOSI by Parsons Brinkerhoff.

\section{c. Process Wastes}

According to the 1985 revised report, any municipal solid waste will be collected and transported to an approved off-site sanitary landfill. Hazardous waste (if any) will be identified and dealt with according to the RCRA regulations. Adequate monitoring by state or federal officials will ensure that these policies are maintained. 


\section{IMPLICATIONS FOR OIL SHALE ENVIRONMENTAL POLICY}

These points of interest only refer to the Proof-of-Concept and not to a production operation. In addition, it is assumed that no surface retorting will be conducted at the C-b site and that there will be a CFBC unit in operation.

It is unlikely that the disposal of boiler ash would place any more significant impact on the environment than the disposal of spent oil shale. All indications from the limited ash test results indicate that the ash will essentially act as an inert rock material in the field disposal area.

Designs for the disposal of spent shale have been performed. These appear to be in order with designs for the disposal of other large volume, bulk mining and processing wastes. Disposal of other solid wastes which might be generated at the C-b site are to be handled in accordance with the current regulations of the State of Colorado. If adequate monitoring is performed by the appropriate state and/or federal personnel, there should not be any significant environmental consequences.

\section{KEY UNRESOLVED ISSUES}

There are several points of interest in the waste disposal/handling plan which should be addressed in the course of the Proof-of-Concept project. The information is warranted in the event alternate operations plans are involved. The rate of boiler ash production is not yet known. So it is not yet possible to estimate the storage volumes required for ash disposal.

The chemical and physical nature of boiler ash is not precisely known. These are simple parameters to identify and should be available soon. In addition, geotechnical parameters should be identified such as: friction angle, cohesion, maximum density, optimum water content, permeability, pozzolanic reactivity. These parameters will facilitate the design of stable dump slopes.

\section{RECOMMENDATIONS}

The following recommendations concern the proposed Proof-of-Concept in-situ retorting oil shale recovery project at the C-b site leased by Occidental Oil Shale Incorporated.

- Previous studies regarding the characteristics and land disposal practices for mined oil shale are sufficient to cover the activities for the proposed Proof-of-Concept with regard to handling of the mined oil shale.

- Details concerning the Circulating Fluidized Bed Combustion process to be installed and operated at the C-b site should be developed and refined. This includes determination of the size of the facility, the location, operating procedures, i.e., quantity of coal and oil shale that the CFBC will utilize daily, quantity of solid waste material that the CFBC will generate, i.e., ash, emission sludge (if any), etc. 
- The characteristics of the boiler and fly ashes should be determined, i.e., chemical constituents and engineering properties. While some of this work has been done the remainder apparently is in progress. A complete characterization of run of plant boiler ash and its behavior under field conditions should be obtained in the course of the Proof-ofConcept project.

- For purposes of the Proof-of-Concept project it is suggested that boiler ash be disposed separately on a graded and compacted surface which will allow collection of leachate and treatment if necessary.

In summation, the solid waste disposal component of the in-situ retorting program does not appear to constitute any major environmental threat. The areas of concern are ground or surface water pollution due to leaching and mass movement of material due to instability of slopes. These areas have already been targeted for and received sufficient study with the exception of the combustion ash handling and disposal. Therefore, provided OOSI examines the noted areas of concern and acts to mitigate them, the solid waste disposal activities should have minimal impact on the environment.

\section{TABLE 1.}

Summary of TCLP extractables from CFBC boiler ash. The oil shale was from Tract C-b, the coal was from a Western Colorado mine and the MIS gas was formulated to approximate the composition of actual MIS gas.

BOILER ASH

\begin{tabular}{rrrr}
\hline & $\begin{array}{c}\text { OIL SHALE, COAL } \\
\text { MIS GAS }\end{array}$ & \multicolumn{2}{c}{$\begin{array}{c}\text { OlL SHALE } \\
\text { ONLY }\end{array}$} \\
\hline RCRA & Fly & Bottom & $\begin{array}{r}\text { Fly } \\
\text { Levels }\end{array}$ \\
& Ash* & Ash** & Ash*** \\
5.0 & 0.403 & 0.022 & 0.044 \\
100.0 & 1.316 & 0.458 & 1.210 \\
1.0 & $<0.050$ & $<0.050$ & $<0.050$ \\
5.0 & 0.134 & 0.09() & 0.170 \\
5.0 & 0.011 & 0.011 & $<0.010$ \\
0.200 & $<0.0001$ & $<0.00(0)$ & $<0.00() 1$ \\
1.0 & 0.061 & 0.021 & 0.084 \\
5.0 & $<0.035$ & $<0.035$ & $<0.035$
\end{tabular}

all values in $\mathrm{mg} / \mathrm{L}$

* averge of five samples

** average of three samples

*** one sample 
Appendix III - Solid Waste

Table 1a

FLY ASH 4/30/90

Lab Name: WESTERN RESEARCH INST

Sample Number

Case No.: ESSINGTON

S-523-90-A

\section{Semivolatile Compounds}

Concentration: Low

Date Extracted: $5 / 22 / 90$

Date Analyzed: 900524 02:37

Conc/Dil Factor: $\mathbf{. 5 0 0 0 0}$

Percent Moisture: 0.0

\author{
GPC Cleanup _ Yes XX No \\ Separatory Funnel Extraction $\mathrm{X}$ Yes \\ Continuous Liquid-Liquid \\ Extraction \\ Yes
}

C.A.S

UG/L.
C.A.S

NUMBER
UG/L.

Phenol

108-95-2

$111-44-4$

95-57-8

$541-73-1$

$106-46-7$

$1(x)-51-6$

95-50-1

95-48-7

$39638-32-9$

106-44-5

$621-64-7$

$67-72-1$

98-95-3

78-59-1

88-75-5

105-67-9

65-85-0

$111-91-1$

120-83-2

$12(1)-82-1$

91-20-3

$106-47-8$

87-68-3

59-50-7

$91-57-6$

$77-47-4$

88-(16-2

95-95-4

$91-58-7$

88-74-4

$131-11-3$

208-96-8 bis (2-Cloroethyl) ether

2-Chlorophenul

1,3-Dichlorubenzene

1,4-Dichlorubenzene

Benzyl Alcohol

1,2-Dichlorobenzene

2-Methylphenol

bis (2-chloroisupropyl) Ether

N-Nitruso-Di-n-Propylamine

IIexachlorocthane

Nitrubenzene

Isuphurone

2-Nitrophenol

2,4-Dimethylphenol

Benzoic Acid

bis (2-Chloructhuxy) methane

1,2,4-Trichlurubenzene

Naphthalene

4-Chloroaniline

Ilexachlorubutadiene

4-Chloro-3-Methylphenol

2-Methylnaphthalene

Hexachlorocyclopentadiene

2,4,6-Trichlorophenol

2,4,5-Trichlorophenol

2-Chloronaphthaiene

2-Nitroaniline

Dimethylphthalate

Acenaphthylene 4-methylphenol

2,4-Dichlurophenol

NLiMBiER

\begin{tabular}{|c|c|c|}
\hline 99.199 .2 & 3-Nitroaniline & 25 \\
\hline $83-32.9$ & Acenaphthene & 5 \\
\hline $51-28.5$ & 2,4-Dinitrophenol & 25 \\
\hline $1(0)-1) 2-7$ & 4-Nitrophenol & 25 \\
\hline $132-64-9$ & Dibenzofuran & 5 \\
\hline $121-14-2$ & 2,4-1Dinitrotoluene & 5 \\
\hline $6(x)-20-2$ & 2,6-Dinitruculuenc & 5 \\
\hline $84-6 x-2$ & Dicthylphthalatc & 5 \\
\hline $7005-72-3$ & 4-Chloruphenyl-phenylether & 5 \\
\hline $86-73-7$ & [iluorenc & 5 \\
\hline $1(x)-0) 1-6$ & 4-. Vitruaniline & 25 \\
\hline $534-52-1$ & 4,6-1Dinitro-2-methyiphenol & 5 \\
\hline $86-30-6$ & N-Nitrososdiphenylamine & 25 \\
\hline $101-55-3$ & 4-Bronophenyl-phenylether & 5 \\
\hline $118-74-1$ & llexachlorubenzene & 5 \\
\hline $87-86-5$ & Pentachloruphenol & 25 \\
\hline $85-(1) \cdot 8$ & Phenathrene & 5 \\
\hline $120-12 \cdot 7$ & Anthracene & 5 \\
\hline $84 \cdot 74 \cdot 2$ & Di-n-Butylphthalate & 5 \\
\hline $206-44-0$ & liluoranthene & 5 \\
\hline $129-()(0)-1)$ & Pyrene & 5 \\
\hline $85-68.7$ & Butylbenzylphthalate & 5 \\
\hline $91-94-1$ & 3,3'-Dichlorobenzidine & 10 \\
\hline $56-55-3$ & Benze(a)Anthracene & 5 \\
\hline 117.81 .7 & bis (2-Ethylexyl) I'huhalate & 3 \\
\hline $218-01-9$ & Chrysene & 5 \\
\hline $117-84-()$ & Di-n-Octylphthalate & 5 \\
\hline $205.99-2$ & Benzo(b)liluoranthene & 5 \\
\hline $207-() 8-9$ & Ben/ar(a)liluoranthene & 5 \\
\hline $50-32 \cdot 8$ & Benzo(a)Pyrene & 5 \\
\hline $193-39-5$ & Indeno(1,2,3-cd)Pyrene & 5 \\
\hline $53-7()-3$ & Diben $z(a, h)$ Anthracenc & 5 \\
\hline $191-24-2$ & Benzo(g,h,i)Perylene & 5 \\
\hline
\end{tabular}

(1) Cannot be separated from diphenylamine 
Appendix III - Solid Waste

Table $1 b$

BOTTOM ASH 4/30/90

Lab Name: WESTERN RESEARCH INST

Sample Number

Case No.: ESSINGTON

S-523-9()-B

\section{Semivolatile Compounds}

Concentration: Low

Date Extracted: 5/22/90

Date Analyzed: 900524 03:33

Conc/Dil Factor: $.50(100$

Percent Moisture: 0.0
GPC Cleanup _ Yes $\mathrm{XX}$ No

Separatory Funnel Extraction X Yes

Continuous Liquid-Liquid

Extraction Yes

C.A.S

$\underline{\mathrm{U}(\mathrm{i} / \mathrm{L}}$
C.A.S

NUMBER
UG/L.

$108-95-2$

$111-44-4$

$95-57-8$

$541-73-1$

1(k6-46-7

$1(x)-51-6$

95-50-1

95-48-7

$39638-32-9$

106-44-5

$621-64-7$

$67.72-1$

$98-45-3$

$78.59-1$

88-75-5

105-67-9

65-85-()

111.91 .1

120-83-2

12()-82-1

$91-20)-3$

$11(6-47-8$

87-68-3

59-50-7

91-57-6

$77-47-4$

88-106-2

$95-95.4$

91-58-7

88-74-4

$131-11-3$

208-96-8
Phenul

bis (2-Clorocthyl) ether

2-Chlurophenol

1,3-Dichlorubenzene

1,4-Dichlorubenzenc

Benzyl Alcohol

1,2-Dichlurobenzene

2-Methylphenol

bis (2-chloroisupropyl) lither

4-mcthylphenol

N-Nitroso-Di-n-Propylamine

Ilexachluroethane

Nitrobenzenc

Isophorune

2-Nitrophenol

2,4-Dimethylphenol

Benzoic Acid

his (2-Chloructhoxy) methane

2,4-Dichloruphenol

1,2,4-Trichlurubenzene

Naphthalcne

4-Chloroaniline

liexachlorobutadiene

4-Chluro-3-Methylphenol

2-Methylnaphthaiene

Ilexachlorocyclopentadienc

2,4,6-Trichlorophenol

2,4,5-Trichloruphenul

2-Chloronaphthalenc

2-Nitruaniline

Dimcthylphthalatc

Acenaphthylene

NLiMBII:R

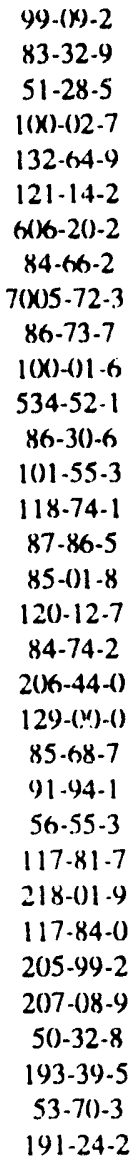

3-Nitroaniline

Acenaphthene

2,4-Dinitrophenol

4-Nitrophenol

Dibenzoluran

2,4-Dinitrotoluene

2,6-Dinitrotoluene

Diethylphthalate

4-Chloruphenyl-phenylether

liluorene

4-Vitroanilino

4,6-Dinitro-2-methylphenol

$N$-Nitrososdiphenylamine

4-Bronuphenyl-phenylether

Ilexachlurubenzene

Pentachlorophenol

Phenathrenc

Anthracene

Di-n-Butylphthalate

Fluoranthene

Pyrene

Butylbenzylphthalate

3,3'-Dichlurobenzidine

Ben zo(a) Anthracene

his (2-lithylcxyl) Phthalate

Chrysene

Di-n-Octylphthalate

Benzo(b)l luoranthene

Beneo(a)liluoranthene

Benzu(a)Pyrene

Indeno(1,2,3-cd)Pyrene

Dibenz(a,h)Anthracene

Ben $\operatorname{co}(\mathrm{g}, \mathrm{h}, 1)$ Perylene

(1) Cannot be separated from

diphenylaminc 


\section{Table 1c}

FLY ASH $4 / 30 / 90$

Lab Name: WESTERN RESEARCH INST

Sample Number

Case No.: ESSINGTON

\section{Semivolatile Compounds}

Concentration: Low

Date Extracted: 5/22/90

Date Analyzed: 900524 04:29

Conc/Dil Factor: .50000

Percent Moisture: 0.0
GPC Cleanup _ Yes $\underline{X X}$ No Separatory Funnel Extraction $X$ Yes Continuous Liquid-Liquid Extraction __ Yes

C.A.S NUMBl:R
C.A.S NUMBIIR
Phenul bis (2-Cloroethyl) ether 2-Chlorophenes!

1,3-Dichlorubenzene

1,4-Dichlorobenzene Benzyl Alcohol 1,2-Dichlorubenzene 2-Methylphenol bis (2-chloroisupropyl) lither 4-methylphenol N-Nitroso-Di-n-Propylamine Hexachlorocthane Nitrobenzenc Isophorone

2-Nitrophenol

2,4-Dimethylphenol

Benzoic Acid

bis (2-Chlorocthoxy) methane

2,4-Dichloruphenol

1,2,4-Trichlorobenzene

Naphthalene

4-Chloroaniline

Ilexachlurobutadicne

4-Chloro-3-Mcthylphenol

2-Mcthylnaphthaicne

Hexachlorocyclopentadicne

2,4,6-Trichlorophenol

2,4,5-Trichlorophenul

2-Chloronaphthaleric

2-Nitruaniline

Dimethylphthalate

Acenaphthylene
UG/L

$\begin{array}{ll}5 & U \\ 5 & U \\ 5 & U \\ 5 & U \\ 5 & U \\ 5 & U \\ 5 & U \\ 5 & U \\ 5 & U \\ 5 & U \\ 5 & U \\ 5 & U \\ 5 & U \\ 5 & U \\ 5 & U \\ 5 & U \\ 0 & J \\ 5 & U \\ 5 & U \\ 5 & U \\ 5 & U \\ 5 & U \\ 5 & U \\ 5 & U \\ 5 & U \\ 5 & U \\ 5 & U \\ 25 & U \\ 5 & U \\ 25 & U \\ 5 & U \\ 5 & U\end{array}$

$99-199.2$

83-32-9

$51-28-5$

(1(x)-(02-7

132-64-9

121-14-2

61)6-20-2

84.66-2

$7(x) 5-72 \cdot 3$

86-73-7

$1(00-01-6$

$534.52-1$

86-30-6

$101-55-3$

118-74-1

87-86-5

85-()1-8

120-12-7

84-74.2

2(16-44-1)

129-()()-0

$85-68-7$

$91.94-1$

56-55-3

$117-81.7$

$218-01-9$

117-84-0

205-99-2

207-08-9

50)-32-8

193-39-5

53-7()-3

191-24-2
3-Nitruaniline

Acenaphthene

2,4-Dinitruphenol

4-Nitruphenul

Dibenzufuran

2,4-Dinitrotoluene

2,6-Dinitruculuene

Dicthylphuthalate

4-Chlorophenyl-phenylether

Fluorene

4-Nitroaniline

4,6-Dinitro-2-methylphenol

$\mathrm{N}$-Nitrosusdiphenylamine

4-I3ronuphenyl-phenylether

Ilexachlorobenzene

Pentachloruphenol

Phenathrene

An'hracene

Di-n-Butylphthalate

Filuoranthene

Pyrene

Butylbenay!phthalate

3,3'-Dichlorubenzidine

Benzo(a)Anthracene

bis (2-lithylexyl) Phthalate

Chrysene

Di-n-Octylphthalate

Benzo(b) Il luoranthene

Benzo(a)] luoranthene

Benzo(a)Pyrene

Indeno(1,2,3-cd)Pyrene

Diben $<(a, h)$ Anthracene

Benzo(g,h,i)Perylene

(1) Cannot be scparated from

diphenylamine 
Appendix III - Solid Waste

Table 1d

FLY ASH $\quad 5 / 1 / 90$

Lab Name: WESTERN RESEARCH INST

Sample Number

Case No.: ESSINGTON

523900

Semivolatile Compounds

Concentration: Low

Date Extracted: $5 / 23 / 90$

Date Analyzed: 900524 23:57

Conc/Dil Factor: .50000

Percent Moisture: 0.0
C.A.S

NUMBI:R
$\mathrm{UG} / \mathrm{L}$

108.95-2

$111-44-4$

95-57-8

$541-73-1$

$1(x-46-7$

$100-51-6$

95-50-1

95-48-7

39638-32-9

$1(6-44-5$

$621-64-7$

$67-72-1$

98-95-3

78-59-1

$88-75-5$

$105-67-9$

$65-85-0$

$111-91-1$

120-83-2

120-82-1

$91-20-3$

$106-47-8$

$87-688-3$

$59-50)-7$

$91-57-6$

$77-47-4$

$88-16-2$

95-95-4

91-58-7

$88-74-4$

$131-11-3$

208-96-8
Phenol

bis (2-Cloructhyl) ether

2-Chloruphenol

1,3-Dichlorubenzene

1,4-Dichlorobenzenc

Benzyl Alcohol

1,2-Dichlurobenzene

2-Methylphenol

4-methylphenol

N-Nitroso-Di- $n$-Propylamine

Ilexachlurocthane

Nitrobenzeric

Isuphurune

2-Nitruphenol

2,4-Dimethylphenol

Benzoic Acid

bis (2-Chloroethoxy) methanc

2,4-Dichluruphenol

1,2,4-Trichlorobenzene

Naphthalene

4-Chloroaniline

Ilexachlorobutadicne

4-Chloro-3-Methylphenol

2-Mcthylnaphutialene

Hexachlorocyclopentadiene

2,4,6-Trichlorophenol

2,4,5-Trichlorophenol

2-Chlorunaphuhalene

2-Nitruaniline

Dimethylphthalatc

Accnaphthylene bis (2-chlorvisupropyl) Ether
C.A.S

NUMBER
GPC Cleanup - Yes XX No Separatory Funnel Extraction $X$ Yes Continuous Liquid-Liquid Extraction Y Yes

UGR 99-(x)-2 3-Nitruaniline 25

$83-32-9$

$51-28-5$

$1(0)-(1) 2-7$

$132-64-9$

$121-14-2$

$6(x-20)-2$

$84-66 \cdot 2$

$7005-72-3$

86-73-7

$100-01-6$

$534-52-1$

$86-30-6$

$101-55-3$

$118-74-1$

$87-86-5$

$85-(01-8$

120-12-7

84-74-2

206-44-1)

129-(X)-()

$85-68-7$

$91-94-1$

56-55-3

$117-81-7$

$218-01-9$

$117-84-0$

205-99-2

207-08-9

50-32-8

193-39-5

$53-70-3$

191-24-2
Acenaphihenc

2,4-Dinitrophenol

4-Nitrophenol

Dibenzoluran

2,4-Dinitrotolucne

2,6-Dinitrutuluene

Dicthylphthalate

4-Chlorophenyl-phenylether

Fluorenc

4-itruaniline

4.6-Dinitro-2-methylphenol

N-Nitrosusdiphenylamine

4-Bronuphenyl-phenylether

Uexachlurubenzene

Pentachloruphenol

Phenathrenc

Anthracene

Di-n-Butylphthalatc

liluoranthene

Pyrene

Butylben/ylphthalate

3,3'. Dichlorobenzidine

Benzu(a) Anthracene

bis (2-E:thylcxyl) Phthalate

Chrysene

Di-n-Octylphthalate

Benzu(b)Illuoranthene

Benzo(a)Fluoranthene

Benzo(a) Pyrene

Indeno(1,2,3-cd)Pyrene

Dibenz(a,h)Anthracenc

Benzo(g,h,i)Perylene

(1) Cannot be scparated from

diphenylarnine 
Appendix III - Solid Waste

Table le

$100 \%$ OIL SHALE BAG HOUSE ASH

Lab Name: WES IERN RESEARCH INST

Sample Number

Case No.: ESSINGTON

S-523-90-E

\section{Semivolatile Compounds}

Concentration: Low

Date Extracted: 5/23/90

Date Analyzed: 90052^ 05:23

Conc/Dil Factor: .50000

Percent Moisture: 0.0
GPC Cleanup _ Yes XX No Separatory Funnel Extraction _ Yes Continuous Liquid-Liquid Extraction __ Yes
C.A.S

NUMIBLR
$\mathrm{LG} / \mathrm{L}$

C.A.S

NLMBIIR

\begin{tabular}{|c|c|c|}
\hline $108-95-2$ & Phenol & 5 \\
\hline $111-44-4$ & bis (2-Cloroethyl) ether & 5 \\
\hline $95-57-8$ & 2-Chlorophenol & 5 \\
\hline $541-73-1$ & 1,3-Dichlorobenzenc & 5 \\
\hline $106-46-7$ & 1,4-Dichlurobenzene & 5 \\
\hline $100-51-6$ & Benzyl Alcohol & 5 \\
\hline $95-50-1$ & 1,2-Dichlorubenzene & 5 \\
\hline $95-48-7$ & 2-Mcthylphenol & 5 \\
\hline $9638-32-9$ & bis (2-chlorvisupropyl) lither & 5 \\
\hline $106-44-5$ & 4-methylphenul & 5 \\
\hline $621-64-7$ & N-Nitroso-Di-n-Propylamine & 5 \\
\hline $67-72-1$ & Hexachloruethane & 5 \\
\hline $98-95-3$ & Nitrobenzenc & 5 \\
\hline $78-59-1$ & Isophoronc & 5 \\
\hline $88-75-5$ & 2-Nitruphenol & 5 \\
\hline $105-67-9$ & 2,4-Dimethylphenol & 5 \\
\hline $65-85-0$ & Benzwic Acid & 25 \\
\hline $111-91-1$ & bis (2-Chloruethoxy) methane & 5 \\
\hline $120-83-2$ & 2,4-Dichlorophenol & 5 \\
\hline 12()$-82-1$ & 1,2,4-Trichlurubenzene & 5 \\
\hline $91-20-3$ & Naphthalenc & 5 \\
\hline $106-47-8$ & 4-Chloroaniline & 5 \\
\hline $87-68-3$ & IIexachlorobutadiene & 5 \\
\hline$\vdots \quad 30-7$ & 4-Chloro-3-Methyiphenol & 5 \\
\hline $91-57-6$ & 2-Metibylnaphthalenc & 5 \\
\hline $77-47-4$ & Ilexachlorocyclopentadiene & 5 \\
\hline $88-(x-2$ & 2,4,6-Trichlurophenol & 5 \\
\hline $95-95-4$ & 2.4,5-Trichlorophenol & 25 \\
\hline $91-58-7$ & 2-Chloronaphthalene & 5 \\
\hline $88-74-4$ & 2-Nitruaniline & 25 \\
\hline $131-11-3$ & Dimcthylphthalate & 5 \\
\hline $208-96-8$ & Acenaphthylenc & 5 \\
\hline
\end{tabular}

99-(x)-2 3-Nitroanilinc $25 \quad$ U

83-32-9 Acenaphthene 5

51-28-5 2,4-Dinitruphenol $25 \quad$ U

100)-(12-7 4-Nitrophenol 25

132-64.9 Dibenzururan 5

121-14-2 2,4-Dinitrotoluene $\quad 5$

6)6-20-2 2,6-Dinitrutoluene 5

84-6x-2 Dicthylphthalate 5 U

7005-72-3 4-Chlurophenyl-phenylether 5 U

86-73-7 Filuorene 5 U

$1(0)-01-6$ 4-Nitroaniline $25 \quad \mathrm{U}$

534-52-1 4,6-Dinitro-2-methylphenol 5 U

86-30-6 N-Nitrosusdiphenylamine $25 \quad$ U

101-55-3 4-Bronuphenyl-phenyicther $\quad 5 \quad \mathrm{U}$

118-74-1 IIexachlurobenzene $\quad 5 \quad$ U

87-86-5 Pentachlorophenol $25 \mathrm{U}$

85-()1-8 Phenathrene 5 U

120-12-7 Anthracenc $\quad 5$ U

84-74-2 Di-n-Butylphthalate $\quad 5 \quad U$

206-44-0) Filuoranthene $\quad 5 \mathrm{U}$

129-(X)-() Pyrenc 5 U

85-68-7 Butylbenzylphthalate $\quad 5 \quad$ U

91-94-1 3,3'-Dichlorobenzidine $\quad 10 \quad \mathrm{U}$

56.55 .3 Benzor(a)Anthracenc $\quad 5 \quad \mathrm{U}$

$117-81-7$ bis $(2-1$ : thylcxyl) Phethalate $\quad 2$ JB

218-(1)1-9) Chrysene 5

117-84-1) Di-n-()ctylphthalate $\quad 5 \quad$ U

205-99-2 Bencu(h)liluoranthene $\quad 5 \quad U$

207-(1)8-9 Benzov(a) Fluoranthene $\quad 5 \quad U$

50)-32.8 Benzo(a)Pyrenc 5

193-39-5 Indeno(1,2,3-cd) Pyrenc $\quad 5$ U

53-70-3 Dibenz(a,h)^nthracene 5 U

191.24-2 Benzo(g,h,i)Perylene 5 U

(1) Cannot be separated trom diphenylamine 


\section{Table If}

BOTTOM ASH 5/1/90

Lab Name: WESTERN RESEARCH INST

Sample Number

Case No.: ESSINGTON

$52390 \mathrm{~F}$

\section{Semivolatile Compounds}

Concentration: Low

Date Extracted: 5/23/90

Date Analyzed: $90052600: 51$

Conc/Dil Factor: .50000

Percent Moisture: 0.0
C.A.S

NUMBER
UG/L.

$108-95-2$

$111-44-4$

$95-57-8$

$541-73-1$

$106-46-7$

$100-51-6$

95-50-1

95-48-7

39638-32-9

106-44-5

$621-64-7$

67-72-1

98-95-3

78-59-1

88-75-5

105-67-9

65-85-()

111-91-1

120-83-2

120-82-1

91-20-3

106-:7-8

87-68-3

59.50-7

$91-57-6$

77.47 .4

88-(x)-2

95-95-4

9i-58-7

88.74-4

131-11-3

208-96-8
Phenol

bis (2-Cloroethyl) ether

2-Chlorophenol

1,3-Dichlorobenzene

1,4-Dichlorobenzene

Benzyl Alcohol

1,2-Dichlorobenzenc

2-Methylphenol

bis (2-chloroisupropyl) Lither

4-methylphenol

Hexachloructhane

Nitrobenzene

Isophorune

2-Nitrophenol

2,4-Dimethylphenol

Benzoic Acid

bis (2-Chloruethoxy) methane

2,4-Dichlorophenol

1,2,4-Trichlorobenzene

Naphthalcne

4-Chloruaniline

liexachlorubutadicne

4-Chloro-3-Mechylphenol

2-Mcthylnaphthalenc

Hexachlorocyclopentadiene

2,4,6-'Trichlorophenol

2,4,5-Trichiorophenol

2-Chloronaphthalene

2-Nitruaniline

Dimcthylphthalate

Acenaphthylene
N-Nitroso-Di-n-Propylamine
C..A.S

NUMBI:R
GPC Cleanup _ Yes XX No Separatory Funnel Extraction $X$ Yes Continuous Liquid-Liquid Extraction _ Yes

\begin{tabular}{|c|c|c|}
\hline 的 & & \\
\hline $83-32-9$ & Acenaphthene & 5 \\
\hline $51-28-5$ & 2,4-Dinitruphenol & 25 \\
\hline $1(x)-() 2-7$ & 4-Nitrophenol & 25 \\
\hline $132-64.9$ & Dibenzoluran & 5 \\
\hline $121-14-2$ & 2,4-Dinitrotuluene & 5 \\
\hline $6(x) 6-20-2$ & 2,6-Dinitrotuluene & 5 \\
\hline $84-66-2$ & Diethylphthalate & 5 \\
\hline $7(x) 5-72 \cdot 3$ & 4-Chlurophenyl-phenylether & 5 \\
\hline $86-73-7$ & Fluorene & 5 \\
\hline $1(x)-(0) 1-6$ & 4-Nitruaniline & 25 \\
\hline $534-52-1$ & 4,6-Dinitro-2-methylphenol & 5 \\
\hline $86-30-6$ & N-Nitrososdiphenylamine & 2.5 \\
\hline $101 \cdot 55 \cdot 3$ & 4-Bronophenyl-phenylether & 5 \\
\hline $118-74-1$ & Hexachlorobenzene & 5 \\
\hline $87.86-5$ & Pentachlorophenol & 25 \\
\hline $85-() 1-8$ & Phenathrene & 5 \\
\hline 12()$-12-7$ & Anthracenc & 5 \\
\hline $84-74-2$ & Di-n-Butylphthalate & 5 \\
\hline $2(16-44-0)$ & liluoranthene & 5 \\
\hline $129-(x)-1)$ & Pyrenc & 5 \\
\hline $85-68-7$ & Butylbenzylphthalatc & 5 \\
\hline $91.94-1$ & 3,3'-Dichlorobenzidine & 10) \\
\hline $56-55-3$ & Benzo(a)Anthracene & 5 \\
\hline $117-81.7$ & bis (2-lithylexyl) Phthalate & 5 \\
\hline $218.011-9$ & Chrysene & 5 \\
\hline $117.84-0$ & Di-n-Octylphthalate & 5 \\
\hline $205-99-2$ & Benzo(b) I luoranthene & 5 \\
\hline $207-0) 8-9$ & Ben zo(a) Fluoranthene & 5 \\
\hline $50-32.8$ & Benzo(a)l'yrenc & 5 \\
\hline $193-39.5$ & Indenu(1,2,3-cd)Pyrene & 5 \\
\hline $53-70-3$ & Dibenz(a,h)Anthracene & 5 \\
\hline $191 \cdot 24-2$ & Benzu(g,h,i)Perylene & 5 \\
\hline
\end{tabular}

(1) Cannol be separated from diphenylamine 
Table 1g

BOTTOM ASH 4/30/90

Lab Name: WESTERN RESEARCH INST

\section{Semivolatile Compounds}

Concentration: Low

Date Extracted: 5/23/90

Date Analyzed: 900526 00:51

Conc/Dil Factor: .50000

Percent Moisture: 0.0

C.A.S

NUMBI:R
Pr.enol

bis (2-Cloroethyl) ether

2-Chlorophenol

1,3-Dichlurobenzene

1,4-Dichlorobenzene

Benzyl Alcohol

1,2-Dichlorobenzene

2-Mcthylphenol

bis (2-chloroisupropyl) lither

4-methylphenol

N-Nitroso-Di-n-Propylamine

Hexachloroethane

Nitrobenzene

Isuphorune

2-Nitrophenol

2,4-Dimethylphenol

Benzoic Acid

bis (2-Chlorocthoxy) methane

2,4-Dichlorophenol

1,2,4-Trichlurubenzene

Naphthale ie

4-Chloroaniline

Hexachlorobuladiene

4-Chloro-3-Methylphenol

2-Mcthylnaphthalene

llexachlorocyclopentadiene

2,4,6-Trichlorophenol

2,4,5-Trichlurophenol

2-Chloronaphihalene

2-Nitroaniline

Dimethylphthalate

Accnaphuhylenc
UG/L.

C.A.S

NUMBI:R
GPC Cleanup — Yes XX No Separatory Funnel Extraction $X$ Yes Continuous Liquid-Liquid Extraction Yes

$131-11-3$

$99-(1)-2$
$83-32-9$
$51-28-5$
$100-(1) 2-7$
$132-64-9$
$121-14-2$
$606-20-2$
$84-66-2$
$7(005-72-3$
$86-73-7$
$1(0)-01-6$
$534-52-1$
$86-30-6$
$101-55-3$
$118-74-1$
$87-86-5$
$85-01-8$
$12(1)-12-7$
$84-74-2$
$2(16-44-0$
$129-00-0$
$85-68-7$
$91-94-1$
$56-55-3$
$117-81-7$
$218-() 1-9$
$117-84-()$
$205-99-2$
$207-08-9$
$50-32-8$
$193-39-5$
$53-70-3$
$191-24-2$
3-Nitruaniline

Acenaphthenc

2,4-Dinitrophenol

4-Nitrophenol

Dibenzoluran

2,4-Dinitronoluene

2,6-Dinitrutolucne

Dicthylphthalate

4.Chlorophenyl-phenylether

Fluorene

4-Nitroaniline

4,6-Dinitro-2-methylphenol

$\mathrm{N}$-Nitrosusdiphenylamine

4-Bronophenyl-phenylether

llexachlorobenzene

Pentachlorophenol

Phenathrene

Anthracene

Di-n-Butylphthalate

IFluoranthene

Pyrenc

Butylhenzylphthalate

3,3'-Dichlorobenzidine

Benzo(a)Anthracene

bis (2-Lithylexyl) Phthalate

Chrysene

Di-n-Octylphthalate

Ben/o(b) liluoranthene

Benzo(a)liluoranthene

Benzu(a)Pyrene

Indeno(1,2,3-cd)Pyrcne

Dibenz(a,h)Anthracene

Benzo(g,h,i)Perylene

(1) Cannol be separated from

diphenylamine 
Table $1 \mathrm{~h}$

FLY ASH 4/30/90

Lab Name: WESTERN RESEARCH INST

Sample Number

Case No.: ESSINGTON

$52390 \mathrm{H}$

Concentration: Low

Date Extracted: 5/23/90

Date Analyzed: 900526 01:45

Conc/Dil Factor: .50000

Percent Moisture: 0.0

\section{Semivolatile Compounds}

C.A.S

NUMBIiR

$108-95-2$
$111-44-4$
$95-57-8$
$541-73-1$
$116-46-7$
$100-51-6$
$95-50-1$
$95-48-7$
$39638-32-9$
$1166-44-5$
$621-64-7$
$67-72-1$
$98-95-3$
$78-59-1$
$88-75-5$
$105-67-9$
$65-85-1)$
$111-91-1$
$120-83-2$
$120-82-1$
$91-20-3$
$106-47-8$
$87-68-3$
$59-50-7$
$91-57-6$
$77-47-4$
$88-(x-2$
$95-95-4$
$91-58-7$
$88-74-4$
$131-11-3$
$208-96-8$

Phenol

bis (2.Cloroethyl) cther

2-Chlorophenol

1,3-Dichlorobenzene

1,4-Dichlorobenzene

Benzyl Alcohol

1,2-Dichlorobenzene

2-Mcthylphenol

bis (2-chloroisopropyl) Lither

4-methylphenol

$\mathrm{N}$-Nitroso-Di- $n$-Propylamine

Hexachlorocthane

Nitrubenzene

Isuphurone

2-Nitrophenol

2,4-Dimethylphenol

Benzoic $\wedge$ cid

bis (2-Chlorocthoxy) methane

2,4-Dichlorophenol

1,2,4-Trichlorobenzene

Naphthalene

4-Chloroaniline

Ilexachlorobutadiene

4-Chloro-3-Methylphenol

2-Methylnaphthalene

Ilexachlorocyclopentadiene

2,4,6-Trichlorophenul

2,4,5-Trichlorophenol

2-Chloronaphthalene

2-Nitroaniline

Dimcthylphthalate

Acenaphuhylene
UG/L.

C.A.S

NUMBLER
GPC Cleanup - Yes $X X$ No Separatory Funnel Extraction $X$ Yes Continuous Liquid-Liquid Extraction _ Yes 
Appendix III - Solid Waste

Table 1i

BOTTOM ASH

Lab Name: WESTERN RESEARCH INST

Sample Number

Case No.: ESSINGTON

523901

\section{Semivolatile Compounds}

Concentration: Low

Date Extracted: 5/24/90

Date Analyzed: 900526 05:21

Conc/Dil Factor: .50000

Percent Moisture: 0.0
GPC Cleanup _ Yes XX No Separatory Funnel Extraction $\mathrm{X}$ Yes Continuous Liquid-Liquid Extraction _ Yes
C.A.S

NUMBIR

$108-95-2$
$111-44-4$
$95-57-8$
$541-73-1$
$106-46-7$
$100-51-6$
$95-50-1$
$95-48-7$
$39638-32-9$
$106-44-5$
$621-64-7$
$67-72-1$
$98-95-3$
$78-59-1$
$88-75-5$
$105-67-9$
$65-85-1$
$111-91-1$
$120-83-2$
$120-82-1$
$91-20-3$
$106-47-8$
$87-68-3$
$59-50-7$
$91-57-6$
$77-47-4$
$88-06-2$
$95-95-4$
$91-58-7$
$88-74-4$
$131-11-3$
$208-96-8$

Phenol

bis (2-Clurocthyl) cther

2-Chlurophenol

1,3-Dichlurubenzenc

1,4-Dichlurobenzenc

Benzyl Alcohol

1,2-Dichlorubenzene

2-Mcthylphenol

bis (2-chloroisopropyl) lither

4-methylphenol

N-Nitroso-Di-n-Propylamine

Hexachlorvethane

Nitrobenzene

Isophorone

2-Nitruphenol

2.4-Dimethylphenol

Benzoic Acid

his (2-Chlorocthoxy) methane

2,4-Dichloruphenol

1,2,4-'Trichlurobenzene

Naphthaienc

4-Chloroaniline

Hexachlorobuladiene

4-Chloro-3-Methylphenol

2-Melhylnaphthalene

Hexachlurocyclopentadiene

2,4,6-Trichlorophenol

2,4,5-Trichloruphenol

2-Chloronaphthalene

2-Nitruaniline

Dimcthylphthalate

Acenaphthylene
C.A.S

NLiMBIIR
UG/L.

$99-(19-2$

83-32-9

$51-28-5$

(1) $(0)-7$

132-64-9

$121-14-2$

6)(6-20-2

84-6x-2

$7005-72-3$

86-73-7

$1(0)-(0) 1-6$

$534-52-1$

86-30-6

$101-55-3$

118-74-1

87-86-5

85-(01-8

120-12-7

84-74-2

2(106-44-0)

$129-(00)-0$

85-68-7

91- $94-1$

56-55-3

$117-81.7$

218-(1)1-9

$117-84-0$

205-99.2

207-(08-9

Sii $32-8$

193-39-5

53-70-3

191-24-2

\begin{tabular}{|c|c|}
\hline 3-Vitroaniline & 2.5 \\
\hline Acenaphthene & 5 \\
\hline 2.4-Dinitruphenol & 25 \\
\hline 4-Nitrophenol & 25 \\
\hline Dibenzufuran & 5 \\
\hline 2,4-1Dinitrotuluene & 5 \\
\hline 2,6-Dinitrotoluene & 5 \\
\hline Dicthylphthalate & 5 \\
\hline 4-Chloruphenyl-phenylether & 5 \\
\hline liluorenc & 5 \\
\hline 4-Nitruaniline & 25 \\
\hline 4,6-Dinitro-2-methylphenol & 5 \\
\hline $\mathrm{N}$-Nitrososdiphenylamine & 25 \\
\hline 4-Bronuphenyl-phenylether & 5 \\
\hline Ilexachlurubenzene & 5 \\
\hline Pentachlorophenol & 25 \\
\hline Phenathrene & 5 \\
\hline Anthracenc & 5 \\
\hline Di-n-Butylphthalate & 5 \\
\hline liluoranthene & 5 \\
\hline Pyrcne & 5 \\
\hline Butylbenzylphuhalatc & 5 \\
\hline 3,3'-Dichlurobenzidine & 10 \\
\hline Benzo(a)Anthracene & 5 \\
\hline bis (2-Ethylexyl) Phuhalate & 2 \\
\hline Chrysenc & 5 \\
\hline Di-n-Octylphthalate & 5 \\
\hline Benzu(b) Fluoranthene & 5 \\
\hline Benzo(a)filuoranthene & 5 \\
\hline Benzo(a)Pyrene & 5 \\
\hline Indeno(1,2,3-cd)Pyrene & 5 \\
\hline Dibenz(a,h)Anthracenc & 5 \\
\hline Benze(g,h,i)Perylene & 5 \\
\hline
\end{tabular}

(1) Cannot be separated from diphenylamine 


\section{APPENDIX IVa}

1. Topic Area: HEALTH AND SAFETY

2. Subtopic: $\quad$ Surface Facilities-Toxic Substances

3. Review Team Leader: Mario C. Battigelli, MD

Director, Institute of Occupational Health

and Safety

West Virginia University

\section{ABSTRACT}

The operations involved in the retort extraction of oil from oil shale present definable risks for the operating work-force, ranging from the well known mechanical trauma associated with mineral extractive activities, to the risks associated with the exposure to the inhalation of airborne products of any mineral excavation and handling. In addition, and distinct from the above we recognize the risks associated with the combustion, partial or complete, of the kerogen and related fuel species.

Any and all of these risks are reasonably well known and quite susceptible to control through the traditional panoply of preventive measures: containment of contaminants, ventilation, use of protective equipment, education, etc.

\section{SUMMARY OF FINDINGS TO DATE}

\section{a. Generalities}

The production of oil shale encompasses a range of operations which are associated with potential and/or real exposure to both solid and gaseous contaminants.

Workers at this operation may, therefore, experience contaminants in different physical and chemical states. In addition, health risks connected with the technology of mining, construction, maintenance, operation of a processing facility and power plant, transportation, distribution and testing all may contribute to the specific and unusual threats of oil shale production/use.

None of these risks are exclusive to this industry and none can be considered unprecedented or uncontrollable. Indeed, traditional means of safety and of industrial hygiene care are applicable to this particular setting, just as they are applicable to the mining industry in general.

The impact of control measures applied to other extractive industries should equal that of general control measures on the population. 


\section{b. Potential Risk Factors}

Data reflecting the actual assessment of these specific risks are not available in the documentation provided by the operator, probably due to the limited and experimental scale of the preliminary operations involving a small number of workers employed over a short duration of time. However, the description of the technology appears quite sufficient to formulate a statement of analysis illustrating the relevant risks, and when coupled with the review of the pertinent literature allow a rather concrete assessment of risk and of remedies. Obviously, data originating from actual observations and measurements based on the experience of workers employed at the MIS retort project will provide more relevant estimates of the specific risk to health.

Overall, the risks anticipated appear to be quite acceptable and consistent with all we know from related experiences in the extractive industry and associated technology.

\section{c. Characteristics of the work place:}

i. $\quad$ Refer to Vol. 1 of RDDP, 1985

ii. Refer to "Health Issues Related to Metal \& Non-metallic Mining", Wagner W.L. et al. eds., Chapter 6, Ann Arbor Science, 1983.

\section{d. Dusts, aerosols and gases}

The operations of preparing and operating the MIS retorts do not differ, in terms of human risk assessment, from any similar procedure employed in the extractive industry. Current guidelines and reports on the exposure (and safety) of workers employed in the extractive industry are perfectly relevant to this issue.

\section{e. Known Effects of Oil Shale Exposure}

The better documented effects associated with the extraction of oil shale are:

i) Mucosal cancers and skin neoplasia (epithelioma)

ii) Pneumoconiosis (a.k.a. "shalosis", a mixed dust pulmonary fibrosis)

a) Neoplasia: the sustained exposure to oil shale, when associated to a pronouncedly deficient personal hygiene, has been connected to skin cancer, particularly scrota! cancer $^{1}$. Actinic keratoses, which occasionally are the forerunner of frank neoplastic processes, have been reported to occur in higher number, in individuals affected but at a lower overall frequency (in terms of number of people affected), in workers of oil shale production ${ }^{2}$. This occurrence appeared to be related to duration of work in specific environments, resulting in protracted exposure to sun light among other factors. 
Other neoplastic processes, including gastrointestinal and respiratory, are also reported to occur at slightly higher frequency than expected, although not reaching any statistical significance. Radioactivity and cigarette smoking, however, have a stronger association with these effects. It is not evident, from the data available, whether the presence of multiple factors, in association with oil shale contaminants, does increase the neoplastic risk with sufficient reproducibility and synergisticality. Recent documentation, reporting current risk estimates, inherent to the extractive industry or use of oil shale is scarce and largely inadequate, preventing a final assessment of the respective carcinogenic risk of oil shale exposure.

The reports from UNOCAL documenting a surveillance program implemented at the Parachute operation site in Colorado, describe the experience of workers employed through the 1986 - 1988 period at that oil shale processing facility ${ }^{3}$. The environmental data presented in these reports do not suggest any sustained excess in exposure, which could be translated in a quantifiable health risks. Similarly, the biological do not support a significant trend toward related effects on the performance or experience of these exposed workers. Major limiting factors in this documentation reside in the inadequate records of occupational history, defining the background of these employees prior to their work at the Parachute site.

b) Pulmonary Fibrosis: Several reports attribute the occurrence of widespread pulmonary fibrosis, with the characteristics of a reticulo-nodular pattern in radiological films of the chest of workers in this segment of the extractive industry to the exposure to mineral dust ${ }^{4}$. The relevance of these findings, in terms of actual or direct responsibility of the oil shale mining operations in causing these respiratory changes remains unclear since differential data on past occupational history are not available.

c) Other Systemic Effects: the operation of retort extraction of oil from shale may expose the operating personnel to a variety of gaseous, liquid or solid materials, including carbon monoxide, combustion products, PAH (polyaromatic hydrocarbons), benzene, etc. It would appear, however, that the exposure to these species on the part of the workers employed in this industry is quite limited and probably readily controllable by elementary monitoring programs. In fact, the retrospective epidemiological study published by $\mathrm{NIOSH}$, resulted in negative findings for morbidity and for mortality of chronic respiratory disorders 5 .

A study of oil shale miners from the Colorado plateau indicated the prevalence of elevated ANA (Antinuclear antibodies) with a frequency of $22 \%$ in the examined subjects ${ }^{6}$. This frequency did not appear to be significant, when paralleled to other individuals.

Furthermore, the addition of products of combustion such as carbon monoxide, oxides of nitrogen, volatile hydrocarbons, etc. to the effluent discharged from the ventilation pipes form the principal hazards for the workers. Their respective risk is obviously geared to the regimen of control and safety employed at the place of work. In this aspect again, oil shale operations, including power production, do parallel the analogous operation of any other fossil fuel operated plant. Hence, the authoritative words of J.Goldsmith, issued for the latter are well applicable to the oil shale operation. ${ }^{7}$ Goldsmith stated then that he could not find much credence in the allegation that "well designed 
modern power plants will produce any serious health effects". This statement, issued some 15 years ago, remains today unchallenged by any observation or report recorded in the intervening years.

d) Injuries: the cohort studied retrospectively by NIOSH, suggested a higher, but not significant, frequency of accident occurrences, in operatives of MIS retorts.

e) Adverse Effects from Physical Exposure: The extensive review of the literature does not elicit significant observations on this account. It does not appear that the oil shale industry is associated with reportable casualties due to exposure to extremes of temperature.

f) Experimental studies: The observation of untoward effects, obtained in animals artificially exposed to oil shale contaminants has rekindled the concerns on the adverse effects of this operation (Holland, L.M. et al., Pulmonary Effects of Shale Dust in Experimental Animals, in Wagner, 1.c.). It should be noteworthy, however, that these studies have been obtained at concentrations (and exposure) far higher than any of the realistic estimates plausible for human exposure, reducing considerably the legitimacy of extrapolating these facts to man. In support of this belief, Coomes's reports add considerable weight of evidence from controlled animal experiments.

\section{IMPLICATION FOR OIL SHALE ENVIRONMENTAL POLICY}

The main problems impinging on the health or survival of workers engaged in oil shale extraction and combustion, as involved in the operation of the MIS retorts demand a forthright and well engineered control program. The justification of this program resides in the fact that these problems are not trivial, even though not terribly detailed in their respective quantitative terms.

Lung fibrosis, lung cancer, skin cancer and skin actinic keratosis, however imprecisely related to the specific exposure at the work site fully warrant a comprehensive preventive program, designed to minimize and/or eliminate the potential risk.

In view of the fact that air pollutants appear to be the main source of the alleged risks described in this working population, air monitoring and control of air contaminants deserve the bulk of the concern and investment toward prevention.

Such control appears quite feasible since the effluent from the combustion, a major vehicle of potential exposure, is channelled through the ventilation stacks. In the absence of quantitative reliable information, the volume of these effluents and their distribution after discharge deserves early attention.

A particular problem is recognized in the polynuclear aromatic hydrocarbons, members of a well known class of carcinogenic species. The few quantitative observations on this class of contaminants provided by the available literature are inadequately documented and therefore unverifiable and of dubious utility. 


\section{Appendix IVa - Toxic Substances}

On the positive side is the absence of need for removal of the solid residue, resulting from the combustion of the shale fuel in-situ. This fact represents a major and unequivocal advantage in respect of the usual problem presented by just about every other retorting process. The limited extent to which residues would be handled sets this technology far apart from any other. The adverse possibility admittedly remains for possible leachates, derived from the combusted rubble. This problem is analyzed in full by the appropriate expert's report.

It should be stated, however, that on the basis of available information, elucidating the dimension of pollutants in the immediate environment of operating MIS retort, the concentration of these contaminants appears minimal and certainly well controllable.

Table 1 (from Hargis \& Jackson, l.c.)

$\begin{array}{lll}\text { Dusts } & \text { Total } & 0.27-2.91 \mathrm{mg} / \mathrm{m} \\ & \text { Respirable } & 0.09-1.20 " \\ & \text { PAH } & 37-689 \mathrm{mg} / \mathrm{m} 3 \\ & & \\ \text { Gases } & \text { Carbon monoxide } & <5 \mathrm{ppm} \\ & \text { Hydrogen sulfide } & <5-10 \mathrm{ppm} \\ & \text { Nitrogen dioxide } & <0.2 \mathrm{ppm} \\ & \text { Sulfur dioxide } & <0.2-1.5 \mathrm{ppm} \\ & \text { Benzene } & <0.02 \mathrm{ppm} \\ & \text { Carbon disulfide } & <50 \mathrm{ppm} \\ & \text { Arsine } & <0.05 \mathrm{ppm} \\ & \text { Toluene } & <0.02 \mathrm{ppm} \\ & \text { Phenol } & <0.002 \mathrm{ppm}\end{array}$

It should be clear that one exception to the generally limited concentrations was observed around the MIS operation. One contaminant class stands head and shoulders above the other: the PAH. A carcinogen is always a tough issue to control. The level advocated by many is zero. It is also considered, in practical terms, unachievable. However, the situation presented by MIS technology is amenable to adequate control, through engineering, monitoring and environmental surveillance. Let it be a reminder, for anyone in need of it that the statistics on hand converge in minimizing if not denying the actual risk of cancer risk. An effective preventive program ought to receive the highest priority in this technology. If implemented, the risks remain remote and theoretical.

\section{KEY UNRESOLVED ISSUES}

The meagerness of objective and well documented data, such as only large population groups could offer, limit the validity of a conclusive assessment. The presence of a large cluster of hypothetical risks associated with the technology of in-situ retort installation alert the preventive 
officer to the task of anticipating and controlling the adverse effects to which workers may be exposed. Trauma, inhalational injuries, long term exposure to carcinogenic contaminants emerge from the analysis as threatening factors, of variable but indisputable importance.

The realization that the technology of the process (i.e. MIS operation) is almost uniquely contained, with defined and logistically limited portals of effluents, encourage a good deal of optimism. Control measures are feasible and likely to be realistically economical.

The volume and the relative characteristics of the contaminants are such to encourage a favorable option for containment and monitoring. The operations, furthermore, are manpower scarce (see manpower per Kwh rating), further minimizing the number of operating personnel involved and, therefore, exposed to the projected risks to health.

The need of pertinent and well focused information remains unmatched, but the task of gathering data is well within the practical reach of limited additional pilot operations.

It seems reasonable to anticipate that the MIS technology will provide important sources of energy within an acceptable range of health risk.

\section{RECOMMENDATIONS}

- A generic program of prevention requires two basic components.

- The first in importance and tactical priority is a sound engineering component. Exposure must be minimized.

- The second component consists of monitoring the personnel exposed. This monitoring begins with the pre-employment scrutiny, to eliminate factors of accrued risk in terms of the individual propensity toward injury or aggravation from exposure of conditions pre-existing employment. Following this baseline appraisal, a periodical surveillance program monitors closely both exposure and possible effects. The surveillance is geared upon medical evaluation, focusing on the assessment of respiratory, cutaneous and metabolic functions, with visual inspection and clinical examination of the target organs. A suitable array of laboratory tests corroborate the clinical inspection, formulated according to the specific guidelines suggested by the program.

- Spirometry, chest X-ray films, and indices of metabolic health are part and parcel of this assessment. As stated, a very important part of this surveillance is the physician evaluation of the specific exposure information, suggesting in turn further or more focused exam procedures.

- Lastly, but second to none, a well conceived program of education must implement any program of prevention. It is a time honored axiom that only a well informed workforce provides the greatest success in controlling hazard. This applies most certainly to the retort 
operation as well. A very important part of this educational input should include emphasis on scrupulous personal hygiene.

\section{Follow-Up and Long-Term Exposures}

An appropriate program to monitor both geographical site and exposed workers should be formulated and implemented at the outset, to verify any possible long term effect(s).

\section{References}

$1 \quad$ Scott, A., Brit. Med. J., 2:1108, 1922; Henry S.A., Am. J. Cancer, 21:28, 1937

2 Costello, 1983, in Wagner, q.v.

$4 \quad$ Wright, W.E., Rom W.N., in V.E. Archer, "Health Implications of New Energy Technology, Ann Arbor Science, 1981, p. 481 and ff., Seaton, A. et al., Thorax 36: 412, 1981

Costello, J., Retrospective Mortality Study of Oil Shale Workers, 1948-1977, mimeographed copy, presented at the 13th Annual Oil Shgale Symposium, Colorado School of Mines, Golden, CO, April 16-18, 1980; Costello J., in Health Issues Related to Metal and Nonmetallic Mining, Wagner et al. eds., 1983 q.v.

$6 \quad$ Olsen, Rom, Wright, 1983, in Wagner et al., q.v.

7 Goldsmith J., Health Hazards from Power Plants, in Energy, the Environment and Human Health, in F.J.Asher editor, Publ. Sciences Group Inc., Acton, MA, 1974

$8 \quad$ Costello, 1983

9 Coomes R.M.,Health Effects of Oil Shale Processing, Quarterly of the Colorado School of Mines, 71: 101-123, 1976; Coomes, R.M. Carcinogenic Testing of Oil Shale Materials, in Proceedings of the 12th Shale Oil Symposium, Colorado School of Mines, April 18-20, 1979). 


\section{APPENDIX IVb}

1. Topic Area: HEALTH AND SAFETY

2. Subtopic: Mine Safety

3. Review Team Leader: Ronald R. Rollins, Professor

Department of Mining Engineering, West Virginia University

\section{ABSTRACT} environment.

Health and safety are always important issues, even more so in an underground, gassy mine

Gas is present in the oil shale strata of the Green River formation. The C-b oil shale mine has been classified as a gassy mine by MSHA since January 2,1980 based on a sample containing $0.289 \%$ methane. This can be controlled by adequate ventilation and according to OOSI personnel at the C-b site no methane has ever been detected by the automatic sensors that are constantly monitoring the mine and the shafts.

Based on a review of the documentation provided and the site visit, it is the reviewer's opinion that the OOSI MIS technique is a technically viable option from the perspective of mine worker safety.

\section{SUMMARY OF FINDINGS TO DATE}

\section{a. Gassy mine rules}

Gas is present in the oil shale strata of the Green River formation. It is believed that the major source of gas during shaft sinking and mining will be by groundwater inflow. Gas may also be liberated by rubblization if it is contained in the pore space of the rock. Gas is also known to exist at greater depths and may diffuse upwards. Uncertainty exists as to the actual concentrations of methane and hydrogen sulfide due to possible dilution with drilling air (1).

The Cathedral Bluff oil shale mine has been classified as a gassy mine by MSHA since January 2, 1980 based on a sample containing $0.289 \%$ methane. The quantity of gas is questionable due to the small amount of data available. Gas released by rubblization poses the highest risk potential but needs to be confirmed by field measurements during a blasting operation. The problems associated with gas liberated from water inflows have been identified, but since the mining horizons are dry and most water comes from the shafts, the gas will either be highly diluted with intake air or immediately exhausted to the surface. Current estimates of groundwater gas are 48 CFM and diffusion gas of $5 \mathrm{CFM}$ for a total of $53 \mathrm{CFM}$. To dilute this to $0.1 \%$, only $53,000 \mathrm{CFM}$ of ventilation air is required which poses no problems. The USBM will be conducting a research effort 
to quantify methane inflows and gas flow permeability of the upper mining interval at Tract C-b. These tests will $\alpha$ - carried out by USBM personnel and equipment and the full time assistance of one Tract C-b employee (2).

The USBM has developed a field and laboratory procedure to characterize gas emission/desorption as well as reaction/sorption rates and volumes and applied it to oil shale samples. This is the proper procedure to use at the CB site (3).

Methane is a common flammable gas. It is non-toxic but may act as an asphyxiant by displacing oxygen. When mixed in the range of 5 to $15 \%$ by volume in air, an easily ignited and explosive mixture is formed. Combustion of methane in a mine atmosphere may produce toxic gases, including carbon monoxide, and an oxygen-deficient atmosphere. Methane has been encountered in exploration holes on the C-b Tract and during shaft sinking. The amount is relatively small and readily controlled by adequate ventilation. Automatic and manual monitoring will permit the shutdown of operations and the evacuation of personnel long before the lower explosion limit is reached. All mobile equipment that will be used beyond the last open crosscut will be rated for use in gassy mines. The threshold limit value (TLV) adopted by the 1973 American Conference of Industrial Hygienists must not be exceeded by any gases or air contaminants. As defined by MSHA and OSHA, the TLV represents the maximum concentration of gas or vapor that a person should be exposed to in an eight-hour day (4).

\section{b. Retorting in mine environment}

The mine and processing facilities for the C-b Tract involve a variety of potential health and safety hazards. A plan has been developed to identify the activities and conditions that pose potentia! health, safety, or security risks; to assure compliance with laws, regulations, and lease terms; and to set forth methods to mitigate health and safety hazards. Mining plans developed by OOSI would provide and maintain working conditions which are as safe and healthful as modern state-of-"..'c-art safety and industrial hygiene practice can provide. A comprehensive health, safety, and security program will be developed and implemented to ensure that these objectives are achieved.

The retorting of oil shale and production of shale oil poses a multiplicity of potential risks. Health hazards associated with retorting include exposure to diesel emissions, oil shalc dust containing silica and possibly other trace elements, noise, heat and cold, high altitude, and potential exposure to a number of hydrocarbons, inorganic gases, trace elements, and shale oil specific compounds. The health and safety program addresses employees as well as the public which includes visitors, trespassers, and the public at large.

A number of meetings have been held with MSHA officials to assure that proper safeguards and protection are provided for the work force. Specific safety manuals and training programs will be developed as the project proceeds. These will include occupational safety, examinations and tests, accident frequency analysis, health and safety training, safety committees, and security. 
Federal and state regulations restrict the use of fires in underground mines. However, a variance to these regulations may be granted when such use is strictly controlled and adequate safety precautions are taken. In the prototype operations at Logan Wash, pyrolysis of the oil shale rubble in the underground retort chambers has been carried to completion and the offgases have been monitored, measured, and prevented from entering the other underground workings used by mine personnel. The present mining plan is based on the experience at Logan Wash and other prototype oil shale mines.

Th: retorts and their products will be completely isolated from the mine atmosphere. Pressure drops across each retort will be monitored and any apparent leakage will be evaluated. Negative pressure maintained in the retorts and their product collection system by the surface exhaust blowers also will serve to cause any leaks to be into, rather than out of, the retort, and the possibility of retort gas entering the mine work areas will, be remote. Sufficient excess mine ventilation will also be provided to dilute any gas leakage to a safe level. Gas monitors will sample the air at strategic locations in the mine and provide a constant check on its oxygen, methane, and carbon monoxide content (4).

As in any fissile shale, oil shale is subject to spalling. The primary area where this is of concern is in the roofs of the underground tunnels, where the safety of personnel and equipment are of concern. OOSI's Tract C-b facility has successfully used roof bolting and wire mesh to control roof fall five years after construction.

The construction of large underground retorts having uniformly sized oil shale particles represents a key element in OOSI's MIS process and the basic building block of the Proof-ofConcept Facility. Retort blasting technology poses a significant challenge from both technical and operational points of view. The mean particle size must be on the order of six inches which is very small relative to the size of these retorts.

More important than the particle size, is the requirement for uniform void fraction distribution laterally across the retort cross-sections. In other words, the original mined-out void volume must be uniformly distributed throughout the final rubble volume, and this void distribution has to be especially uniform laterally across the retort. The most significant factor working against producing a uniform void fraction distribution is the expansion of shale into limited void volumes, i.e., volumes that can be significantly less than the free bulking volume of the blasted rock, which results when the shale is blasted into unlimited or completely unconfined void volumes. Blasting into limited void volumes severely inhibits the bulking process, and particularly affects expansion of the rock in the vicinity furthest away from the free-face. Creating this void volume requires excavating the proper percentage of oil shale properly distributed within the proposed retort zone. This mining operation necessitates removing the shale rock to the surface with subsequent handling and disposal in conformance to environmental requirements.

Most large-scale commercial blasting operations have access to the blasted rubble in case secondary or corrective blasting may be necessary due to faulty blasting components or operational difficulties. After a retort is rubblized, however, there is no easy access and little or no remaining void to blast into, even if access was possible. Thus, every effort must be made in advance to ensure 
that a retort blast has the greatest chance for success that is possible, even if it requires developing new blasting technology and improving operational procedures by practicing the most important features of retort blast designs. The reliability factors of the detonating devices and the explosive products must be determined, improved and verified in large-scale operational tests. Finally, the retort blast must be designed to account for the inherent uncertainties present in any blast and exhibit high enough levels of redundancy to give the best chance for success.

In-situ methods require that the shales/marlstones be fragmented in place to induce adequate porosity and permeability to allow in-situ heating of the fragmented shales. This can be accomplished by using explosives. However, it has been found that the existing blasting systems, though very efficient, have some drawbacks. The explosives become insensitive when shot in multiple vertical decks. They can also become insensitive when spaced horizontally at close proximity to other charges. Also, since the blasting is done in a very limited free face, the delay time that can be allowed between charges is also quite limited. Consequently, it is not always possible to routinely predict the performance of the blasting system. Furthermore, since it is not possibie to undertake secondary blasting, it is imperative that the blast design function properly. The successful retorting by OOSI of Retorts 7 and 8 suggests that some of these problems may have been overcome. Also, more recently, in 1989, high precision delay blasting caps have been developed and are now available that will also help in resolving any delay problems that may have been experienced in the past.

Of all the systems under consideration, the MIS has the potential of recovering a larger percentage of the resource. However, this system requires that the oil shale blocks be developed by mining and then fracturing in such a way that the particle size of the rubble is uniform and that adequate permeability and porosity is available for the heat front to travel down the fragmented block. The major problem has been the inibility to fragment shale blocks on a commercial scal:: with some degree of predictability. A major stumbling block seems to be the blasting system--explosives, firing systems, and the detonators. It appears that OOSI may have overcome some of these problems as illustrated by their success with Retorts 7 and 8 . It remains to be seen if this can be done on a commercial basis.

\section{IMPLICATIONS FOR OIL SHALE ENVIRONMENTAL POLICY}

From an environmental standpoint the mine safety aspects of gassy mine rules and retorting in mine environments are not major problem areas. The C-b site development is constantly monitored for methane but none is recorded by the sensors due to the more than adequate ventilation procedures used and the very small quantities released by the mining. The underground retorting is done in a positive downdraft method which draws the air in from the surface and the pyrolysis products downward to collection points. 


\section{KEY UNRESOLVED ISSUES}

This reviewer sees no unresolved issues from a gassy mine rules or retorting in mine environment standpoint. These issues have been adequately addressed.

\section{RECOMMENDATIONS}

The success of OOSI retorts 7 and 8 may suggest some of the problems associated with the MIS technique have been overcome, or are not as critical as they seem on small-scale retorts.

Based on a review of the literature available to me and on the site visit to Logan Wash and the C-b site it appears that the Occidental Oil Shale, Inc. MIS approach for shale oil recovery is a viable option for commercial development and is environmentally safe from a gassy mine and rubblized in-situ retorting standpoint.

\section{REFERENCES}

1. Archive Document: "C-b Shale Oil Venture--Reports on Methane Occurrence," by C. A. Nieuwenhuis, January 1979.

2. Archive Document: "Methane at CB," by T. L. Watson, August 1983.

3. $\quad$ Experimental Procedure to Examine Gases Released from or Reacted with Mine Rocks and Atmospheres; Examples from Oil Shale," by David M. Hyman, PRC, USBM, Pittsburgh, PA, August 1984.

4. Archive Document: "Health and Safety Description from 1984 Detailed Development Plan," Part 6 on Environmental Effects and Control Plans. 


\section{APPENDIX IVC}

1. Topic Area: HEALTH AND SAFETY

2. Subtopic: Shale Oil Handling/Transportation

3. Review Team Leader: Wahab Khair, Professor

Department of Mining Engineering, West Virginia University

4. ABSTRACT

This report presents an evaluation of shale oil handling and transportation, with respect to health and safety, in reactivating the Occidental Oil Shale Tract C-b operation near Meeker, Colorado. Assessment of proposed processes and technology associated with the above mentioned products was made from reports provided by Occidental Oil Shale, Inc. (archives of Occidental Oil Shale in Pallisade, Colorado), and also from discussions held with Occidental personnel at C-b and Logan Wash sites during tours, April 11, 1990. Evaluation of the proposed process and technology was made based on their compatibility with state of the art.

There are two options for transportation of the shale oil. Option one would have trucks haul the oil to Unocal's upgrader at Parachute Creek, Colorado. It is estimated that this would mean nine tanker truckloads per day and not place any significant burden on the route. The second option involves transporting of shale oil truck to a rail terminal and then to remote coastal markets by train. Both options involve conventional technology and no problems are anticipated.

\section{SUMMARY OF FINDINGS TO DATE}

Two types of products, namely raw shale oil and syncrude are associated with handling, transportation, and ultimate maketing of the oil product from the C-b site. It is estimated that, under full-scale commercial operations, 4.5 billion barrels of shale oil could ultimately be recovered from the $\mathrm{C}-\mathrm{b}$ site. The rate of shale oil production during the Proof-of-Concept project at the C-b plant will be approximately 1200 barrels a day.

Two options have been recommended for transportation of the shale oil. Option one would have trucks haul the oil to Unocal's upgrader at Parachute Creek, Colorado. There is a possibility of accidental oil spills which may affect the safety of associated highways as well as be a potential danger to the health and safety of the drivers. Furthermore, oil spills may affect the local environment and endanger the lives of local inhabitants. However, oil handling and transportation by conventional storage and trucking are common practice in the oil industry and although there is a possibility for accidents the highly evolved technology makes accidents minimal. 


$$
\text { Appendix IVc - Shalc Handling/Transport }
$$

The second option differs from the first in that shale oil would be trucked to a railhead rather than to the Unocal upgrader. The railhead would either be at Rifle or Craig, Colorado.

Proposed shale oil storage, handling and transportation for the Proof-of-Concept project includes state of the art technology. Necessary measures are planned to minimize hazards. For example, internal floating roof has been used in the storage tanks to prevent drowning of birds in the tanks.

\section{IMPLICATIONS FOR OIL SHALE ENVIRONMENTAL POLICY}

The proposed storage and handling of shale oil includes state of the art technology. Necessary measures have been cited to avoid accidents.

\section{KEY UNRESOLVED ISSUES}

The volume of coal, its route to the plant and the traffic loads on associated highways have not been resolved. This information will not be available until tests determining the source and quantity of coal required in the Circulating Fluidized Combustion power plant C-b site are completed.

\section{RECOMMENDATIONS}

The issues related to off-site transportation of shale oil are considered minor and within the realm of conventional oil handling and safety procedures.

\section{REFERENCES}

(1) Personal communications, visit of the site, and interview of Occidental Oil Co. Personnel, A. W. Khair, April $11-12,1990$.

(2) Archive Document: "Delivery of Syncrude by GATX, Denver Rio Grande Railroad, 1984." 


\section{APPENDIX Va}

1. Topic Area: $\quad$ LAND

2. Subtopic: Subsidence

3. Review Team Leader: $\quad$ Syd S. Peng, Professor and Head

Department of Mining Engineering

West Virginia University

\section{ABSTRACT}

Two mine plans were identified. For one plan, subsidence prediction was performed to determine the size of the shaft pillar using the British National Coal Board method developed in 1975 and that proposed by Abel and Lee in 1980. In the final plan, the panels in the proposed development plan were designed not to subside. The validity of the design hinges on pillar design methods, because the pillar design methods by two separate groups produced considerable difference in pillar strength.

\section{SUMMARY OF FINDINGS TO DATE}

Two mine plans developed in the 1980's were identified as relevant to this review. The first or initial mine plan involves only clusters of modified in-situ (MIS) retorts laid out in two panel forms. The second or the latest mine plan consists of two parts (Figure 1): one is a room and pillar mining section, which requires a surface retort to process the mined-out run-of-mine shale, and the other is an MIS section. In the Proof-of-Concept project only seventeen MIS retorts will be developed while the access ways and retort dimensions will be similar to the plan in Figure 1.

Surface subsidence prediction was performed for the first mine plan (Case 11G or Case 13H) using the British National Coal Board method developed in 1975 and one proposed by Abel and Lee in 1980. The purpose of the prediction was to determine the magritude and extent of surface subsidence on the shaft pillar due to subsidence over the panels of retort clusters. There are two types of retort clusters in this mine plan. Panels A-F on the left side of the shaft pillar consist of 11 rows of retort clusters each of which consists of 6 retorts, $165 \mathrm{ft}$. by $165 \mathrm{ft}$. in plan and $290 \mathrm{ft}$. high. The gas barrier pillar between retorts in each cluster is $50 \mathrm{ft}$. wide and the support pillar between each cluster is $150 \mathrm{ft}$. wide. Retort clusters east of the shaft pillar (panels G-H) consist of three retorts in each row cluster, $165 \mathrm{ft}$. by $380 \mathrm{ft}$. in plan and $290 \mathrm{ft}$. high. The gas barrier pillars between retorts in each cluster and support pillars between clusters are $50 \mathrm{ft}$. wide. Panels are separated by access pillars $300 \mathrm{ft}$. wide. Overburden is $1300 \mathrm{ft}$. thick. The sequence of mining is panels E-C-A-F-D-B in counterclockwise sequence and ends in panels $\mathrm{G}, \mathrm{H}$, etc. 


\section{Appendix Va - Land - Subsidence}

The angle of draw (alpha) varies with rock types and is predicted by a formula proposed by Abel and Lee as follows:

$$
\begin{aligned}
& \alpha=30.2^{\circ}-0.22^{\circ} \mathrm{SS}-0.608^{\circ} \mathrm{LM} \\
& \alpha=8.3^{\circ}
\end{aligned}
$$

where SS and LM are percents of sandstone $(61 \%)$ and limestone $(94 \%)$ in the overburden. To assure a $95 \%$ confidence level, two standard deviations are included; thus

$$
\alpha=8.3^{\circ}+2 \times 4.3^{\circ}=16.9^{\circ}
$$

which produces an influence zone beyond the edge of the panel of $395 \mathrm{ft}$. for a mining depth of 1300 ft.

Maximum subsidence was predicted by the National Coal Board's method. This method requires the prior knowledge of maximum subsidence. Maximum subsidence will be contributed by two processes: one is plenum collapse and pillar crushing and the other is rubble consolidation. Subsidence due to plenum collapse was determined as follows: it employed the empirical equations developed by Abel and Lee relating surface subsidence with depth, mining height, pillar width, and extraction ratio.

For panels $A-F$

$\mathrm{S}_{15}$ (assuming $15 \mathrm{ft}$. plenum collapse) $=1.45 \mathrm{ft}$.

$\mathrm{S}_{3}$ (assuming $3 \mathrm{ft}$. plenum collapse) $=0.09 \mathrm{ft}$.

For panels G-H

$$
\begin{aligned}
S_{15} & =5.08 \mathrm{ft} . \\
S_{3} & =0.44 \mathrm{ft} .
\end{aligned}
$$

Subsidence due to rubble consolidation was determined assuming both the pillar and rubble consolidate in proportion to the area of the rubble or extraction ratio as follows:

For panels A-F

$$
\mathrm{S}_{\mathrm{RL}:}=9.28 \mathrm{ft} .
$$

For panels G-H

$$
\mathrm{S}_{\mathrm{RE}}=15.7 \mathrm{ft} .
$$


The total subsidence is the summation of those two processes. But it needs to be corrected to take care of virgin ground and panel widths less than the critical width for final true subsidence. The final subsidence is then:

$\begin{array}{ccrcc} & & \begin{array}{c}\text { After } \\ \text { Correction } \\ \text { for Virgin }\end{array} & \begin{array}{c}\text { After } \\ \text { Correction } \\ \text { for Panel } \\ \text { Width (ft.) }\end{array} \\ \text { Panel } & \text { Case 1 } & \frac{\text { Total (ft.) }}{10.73} & \frac{\text { Ground (ft.) }}{9.65} & 8.90 \\ \text { A-F } & \text { Case 2 } & 9.28 & 8.35 & 7.70 \\ \text { Panel } & \text { Case 1 } & 20.78 & 18.70 & 17.20 \\ \text { G-H } & \text { Case 2 } & 15.70 & 14.10 & 13.00\end{array}$

Based on the calculated maximum subsidence and angle of draw, subsidence profiles were determined across panels A-C-E and panels G- $\mathrm{H}$, from which it was concluded that less than $400 \mathrm{ft}$. around the edge of the shaft pillar will be affected by subsiding ground leaving an unaffected shaft pillar core of $1950 \mathrm{ft}$. Sor surface facilities.

No surface subsidence prediction was performed for the second or the latest mine plan (Fig. 1), because the mine plan employed various pillars sufficient to support the overburden without collapse. This mine plan has been adopted for future mine development. In this respect, methods of pillar design and entry width need to be reviewed.

All access drifts of 30-50 ft. wide appear to be stable as demonstrated in Retorts \#7 and \#8 and at the shaft bottom of the Tract C-b facilities. Data from Retorts \#7 and \#8 indicated that roof collapse only reached $30-50 \mathrm{ft}$. above the roof of the retort chambers. Therefore opening sizes were well designed and would not induce any stability problems.

Pillar designs were performed by two groups. One was Prof. Abel of the Colorado School of Mines who used the confined core concept developed by Wilson of the British National Coal Board and Agapito of J. F. T. Agapito Associates, Grand Junction, Colorado who used the induced horizontal stress method developed as a result of field investigation at nearby Colony Mine. In the confined core method, a pillar is assumed to consist of two parts: an intact core surrounded on all edges by a failed skin. The failed skin portions reinforce the intact core. The Mohr-Coulomb criterion is then utilized to determine the pillar strength based on triaxial laboratory testing data. The induced horizontal stress method utilizes the stresses in the underground pillars determined by overcoring method before and during failure. The measured stresses are then used to find a relation between the maximum shear stress and the normal stress at failure.

The pillar strengths determined by both methods are quite different (Fig. 2). The induced horizontal stress method will predict higher strength when pillars are greater than $76 \mathrm{ft}$. wide. The discrepancy becomes larger as pillar size becomes bigger. For pillars smaller than $76 \mathrm{ft}$. the reverse 
is true. Thus the mine plans designed by both methods will be considerably different. As a compromise, the average strength of these two methods was used for the design.

The geological conditions for Tract C-b were well studied: stratigraphic sequence identified, strength/RQD for each stratum determined, and joints/fractures of major significance determined. However in-situ stresses were not measured for mine design modelling.

\section{IMPLICATIONS FOR OIL SHALE ENVIRONMENTAL POLICY}

In order to prevent surface subsidence, it will be necessary to specify the minimum size of various types of pillars including access pillars, gas barrier pillars and retort pillars to fully support the overburden without collapse taking into consideration the supporting effects, if any, of the rubblized retort materials.

\section{KEY UNRESOLVED ISSUES}

The oil shale rock strength developed by two separate groups shows considerable difference. Thus the pillar strength issue should be reviewed with any new data incorporated into the analysis and a consistent value should be derived based on sound engineering practice. Strength properties of spent shale in the retorts must be determined for evaluation of collapse and confinement potential.

\section{RECOMMENDATIONS}

- Since the whole idea is to develop a mine plan which will not subside, its key factor is pillar strength. In view of the difference produced by the two methods used, an underground test section to evaluate the in-situ pillar strength is highly recommended.

- In-situ stresses in the proposed development area should be determined and used in pillar design.

- The subsidence prediction technique used in this project was developed by the British National Coal Board which has been proven unsuitable for U.S. coalfields. Several new techniques have since been developed for the U.S. coalfields. These should be investigated for application in oil shale. 
Appendix Va - Land - Subsidence

Figure 1

Cathedral Bluffs General Layout

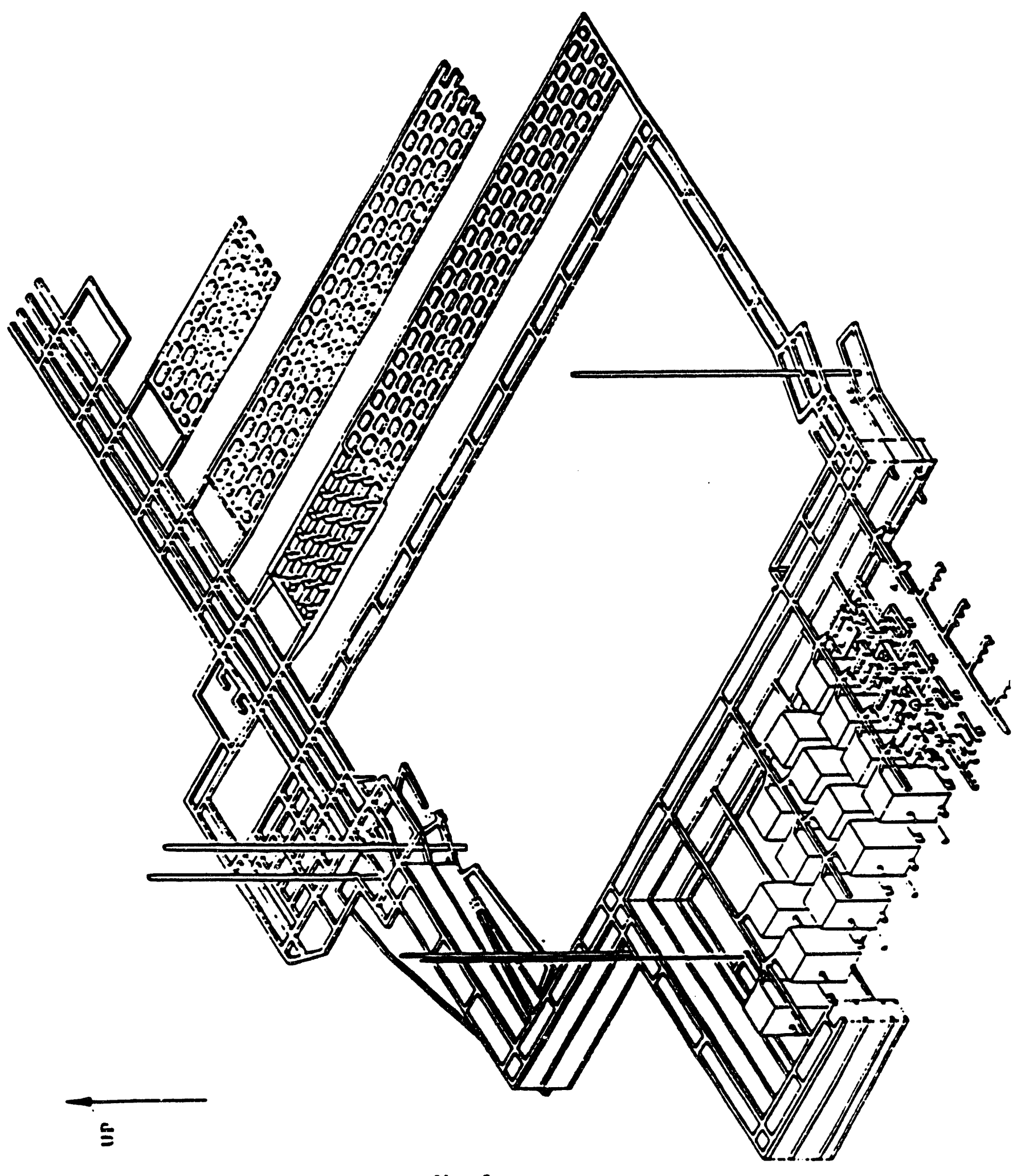

Va- 5 
Figure 2

Comparison of Pillar Strength Design Methods

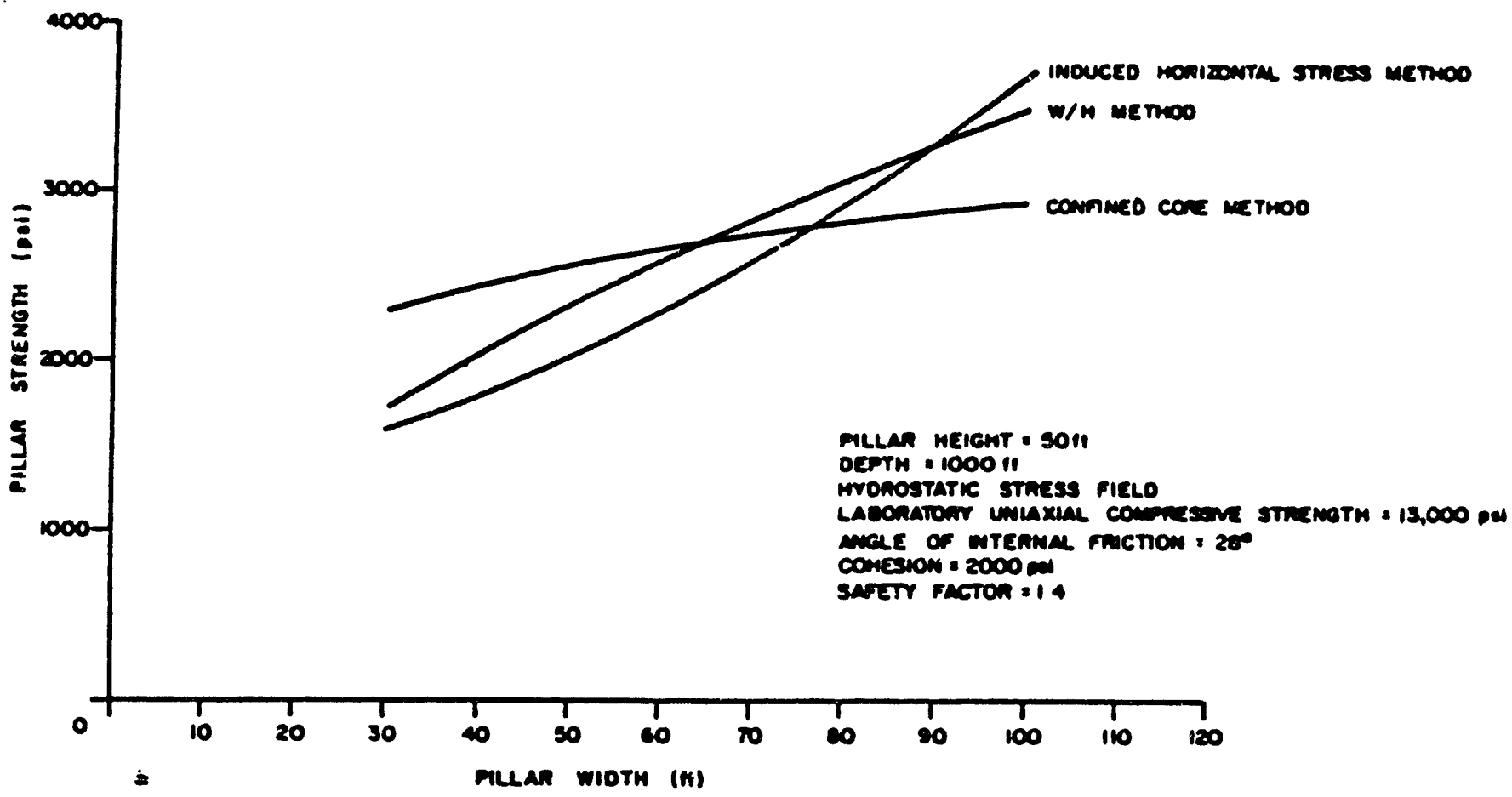




\section{APPENDIX $\mathrm{Vb}$}

\section{Topic Area: $\quad$ LAND}

2. Subtopic:

3. Review Team Leader:

\author{
Reclamation
}

Jeff Skousen, Assistant Professor

Division of Plant and Soil Sciences

West Virginia University

\section{ABSTRACT}

Disturbance of land in the Proof-of-Concept Facility will be limited to the construction of a boiler ash dump and possibly a spent shale dump. Reclamation of surface disturbances around injection holes, coring operations, and installation of the MIS gas collection shaft present few problems to revegetation specialists. Revegetation of such sites can be done quickly and effectively.

Revegetation of boiler ash has not been studied. However, retorted or spent oil shale has been studied extensively. Boiler ash is likely to be similar to spent shale and differs primarily in the addition of some proportion of coal ash and the amount of carbon remaining in the ash. Some spent shales have carbon residues of +4 weight percent while boiler ash carbon content will be much lower (less than 1 percent) and has properties like "Lurgi" spent shale. The characteristics of spent shale commonly causing problems relative to revegetation are coarse particle size, dark color, high salt content, and low amounts of nitrogen and phosphorus.

Practice: used to overcome deleterious properties of raw and spent shale are topsoiling, addition of organic matter, fertilization, mulching, irrigation, and seeding of adapted plant species.

Upon review of numerous scientific experiments conducted over the past 30 years in the area and analysis of demonstration plots constructed at the C-b site, revegetation of surface disturbances, of raw and processed shale piles, and of boiler ash dumps created during the project will not present major challenges. The experimental and demonstration revegetation trials demonstrate that with careful planning and timely application of topsoil, amendments, and seed from adapted plant species, revegetation can be successfully accomplished and completed concurrent with project operations.

State and federal revegetation requirements concerning plant cover and productivity can also be met. Environmental concerns relative to deposition of raw and processed shale and boiler ash on the surface and their revegetation are not warranted when recommendations for their revegetation are followed. 


\section{SUMMARY OF FINDINGS}

\section{Land Characteristics}

Oil shale lands cover some 25,000 square miles $\left(64,720 \mathrm{~km}^{2}\right)$ or 16 million acres $(6.5$ million ha) located primarily in the Green River geological formation in Utah, Colorado, and Wyoming. Approximately 70 percent of the oil shale land area contains suitable amounts of oil for commercial development. This is the world's largest known area of oil reserves, estimated to contain some 600 billion barrels of oil (Schramm 1975).

The oil shale area in this three-state region is generally rolling. However, steep, picturesque cliffs where the Colorado River and numerous perennial and seasonal streams dissect the land create a mosaic ci land forms and patterns. Topography of the area includes high plateaus, mesas, and basins. The climate is arid to semiarid with precipitation ranging from 6 to 20 inches $(15$ to $50 \mathrm{~cm}$ ).

Natural vegetation is sparse but is quite variable due to the differences in soil (especially with depth) and altitude. Low areas are dominated by sagebrush-greasewood (Artemisia-Sarcobatus spp.), and uplands are dominated by pinyon-juniper (Pinus edulis-Juniperus osteosperma) woodlands and some mountainbrush areas (Cercocarpus-Purshia-Cowania-Quercus spp.). High altitudes support Douglas fir (Pseudotsuga menziesii), ponderosapine (Pinus ponderosa), and aspen (Populus tremuloides) forests (Cook 1974).

\section{Retorting Processes}

Several patented processes have been developed during the past 30 years for extracting oil from shale in this vicinity. Early processes required underground mining, transport of the shale to the surface, and retorting in an aboveground facility. The spent shale (also called processed or retorted shale) was then disposed of by constructing large spent shale dumps or returned underground to mined-out areas. Both techniques were expensive and caused environmental concerns dealing with subsidence, pollution of ground and surface waters, revegetation, and dump stability.

In-situ techniques involved fracturing and heating the oil shale in place. Technological problems with size of underground retorts, heating constraints, and collection of the oil have hampered the development of this technique. Advantages to this technique are fewer people are needed to operate the facility, lower water requirements, and substantially lesser amounts of overburden and spent shale are generated requiring revegetation (Davis 1978).

Modified in-situ techniques combine underground mining with underground retorting and the potential of surface processing of shale. The process developed by Occidental Oil Shale, Inc. is a modified in-situ technique. Understanding the various techniques to process oil shale in surface retorting and combustion operations is important because each type of spent shale and/or boilerash has different properties which affect its ability to be stabilized and revegetated. 


\section{Characteristics of Occidental Processed Shale}

The following discussion relates to information developed over the years on spent, or processed oil shale. It differs from the boiler ash to be generated in the Proof-of-Concept Facility in that it has no coal ash component and that its reaction conditions are different. As information relative to boiler ash becomes available, it will be evaluated as a plant growth medium.

Preliminary studies to date on boiler ash show that it is composed of approximately 80 percent fines (or material that is less than $2 \mathrm{~mm}$ ) and contains little carbon. It is easily wetable and is light brown in color. Aside from the fine particle size and wetability of the boiler ash, it is expected that boiler ash will be similar to processed shale in other physical and chemical properties so the following discussion makes use of the spent shale database.

Physical and chemical characteristics of processed shale are given in several reports. In general, the processed shale is coarse with approximately 80 percent of the material greater than 2 $\mathrm{mm}$, and the remaining fine earth fraction (or the amount less than $2 \mathrm{~mm}$ ) having a silt loam texture. The coarseness of the material and its resistance to wetting combine to produce a substrate with low water-holding capacity. Boiler ash should have, based on its particle size and hygroscopic nature, improved water-holding capacity.

Paste $\mathrm{pH}$ of spent shale is 8.0 and electrical conductivity is $13 \mathrm{mmhos} / \mathrm{cm}$. Salt content and especially sodium (3000 ppm and SAR equal to 20) is high. Spent shale is also deficient in nitrogen and phosphorus, and is dark gray to black in color.

During surface retorting, the raw shale fines generated during the process might be co-disposed with the spent shale if not combusted. Raw shale fines represent about 10 percent of the total volume of material being deposited. The raw shale has characteristics similar to spent shale except that it contains about 20 percent carbon versus 10 percent carbon in spent shale.

Revegetation studies have been conducted over the past several years on raw shale and also on Unishale B processed shale from the C-b site. Vegetation can be established directly on spent shale. Greater" vegetation cover and productivity have been demonstrated in numerous studies by covering the spent shale with topsoil in various thickness. Topsoil alleviates vegetation problems related to the coarse nature of the material and the high salt content. The deficiencies in $\mathbf{N}$ and $\mathbf{P}$ can be corrected by fertilization and high surface temperatures can be reduced by niulching. Unocal has reportedly had good success with reclaiming and revegetating a 3 million ton spent shale dump.

\section{Topsoil}

Slow establishment and growth of plants directly on spent and raw shale caused researchers to look at alternatives. With time and further experimentation, spent shale was either mixed with topsoil in the r'sot zone or was covered with different thirknesses of topsoil to determine optimum rates of mixing or optimum depths of topsoil for plant growth. Six, twelve, and eighteen inches of topsoil were applied to several experiments at the C-b site. Results of the demonstration piots over 8 years indicated that the thickest topsoil treatment showed the highest plant cover and production 
but it was not significantly greater than the 12-inch topsoil plots. Topsoiled plots significantly outperformed non-topsoiled plots in almost all instances. Roots of plants grown on topsoiled plots readily penetrated into spent shale and there appeared to be no limitation for roots to cross the soil-spent shale interface.

Topsoil needed for placement on the surface of constructed spent shale piles will be generated from topsoil removed at the site of pile construction. Availability of topsoil for replacement appears adequate from soil reports and from personal knowledge of the area. In this region, soil thickness varies from 4 to 8 inches $(10$ to $20 \mathrm{~cm}$ ) on hillsides to 10 to 30 inches $(25$ to $75 \mathrm{~cm}$ ) in valley bottoms.

\section{Sewage Sludge}

Sewage sludge was used in revegetation demonstration plots at C-b. Results over 6 years showed that topsoiled spent shale with sludge resulted in high vegetation cover (nearly 4 times greater than controls) and production (nearly double the biomass over controls).

\section{Mulching}

Mulching has received attention in many studies. Experiments demonstrate that mulching reduces erosion by reducing raindrop impact and slowing wind erosion. Mulching also helps bind soil particles together and improves water relations in coarse and fine materials. Using a light-colored mulch reflects solar radiation thereby reducing surface temperature. Mulched plots were shown to improve plant establishment of grasses and forbs.

\section{Irrigation}

Irrigation has been used in many experiments and was also used in several studies at the C-b Tract. The addition of 3 to 8 inches $(8$ to $20 \mathrm{~cm}$ ) of water greatly enhanced the establishment and growth of grasses and forbs on these sites. During subsequent years, irrigation was not used in some cases, and the vegetation maintained itself. Occidental proposes to irrigate during the first year of vegetation establishment on reclaimed areas. Irrigation also will help to leach salts in the shale and boiler ash.

\section{Nutrients}

Nutrient levels, especially nitrogen and phosphorus, are known to be limiting to plant growth in spent shale. Nutrient levels (after N-P-K fertilization), micronutrient concentrations, and toxic elements on reclaimed spent shale piles and their effect on plant growth have also been studied and reported. The results show that these parameters do not limit plant establishment as long as N-P-K fertilizer is applied at the appropriate rates. 
Salts

Salts have been reported at high concentrations in raw and spent shale. Cultural treatments such as topsoiling, irrigation (leaching of salts) and fertilization have reduced the susceptibility of plants to salt toxicity. Selection of plant species tolerant of high salt content is also important for establishment and growth of plants.

\section{Vegetation Establishment and Plant Species Trials}

Plant species have been selected and tested at numerous sites in this three-state oil shale area. Plant adaptability trials in greenhouses and in the field suggest that several salt-tolerant species will establish and grow directly on raw shale and on spent shale. Early research found that tall wheatgrass (Agropyron elongatum), a salt tolerant grass, to be the most successful on spent shale.

Through review of the literature on plant species trials, Occidental has developed their own species mixture for seeding spent shale piles. Their mixture involves six wheatgrasses (Agropyron spp.), smooth brome (Bromus inermis), and two wildryes (Elymus spp.). Forbs include milkvetch (Astragalus cicer) and alfalfa (Medicago sativa). Shrub seed is also included in the mixture with big sagebrush (Artemisia tridentata), four-wing saltbush (Atriplex canescens), winterfat (Ceratoides lanata), ephedra (Ephedra viridus), and bitterbrush (Purshia tridentata).

The company has also selected a few other shrubs and trees that can be transplanted after the first year (e.g. 1-0 stock).

All of the named plant species have demonstrated good seeding success and plant establishment and growth on plots at C-b.

\section{IMPLICATIONS FOR OIL SHALE ENVIRONMENTAL POLICY}

The findings from reviewing the litc rature on this topic area and reviewing the plan proposed by Occidental demonstrate that revegetation of raw and spent shale (and also boiler ash) is generally successful if recommendations and precautions are followed. Occidental's revegetation plan is compatible with current state of the art knowledge of revegetation practices.

\section{KEY UNRESOLVED ISSUES}

The technology, as presently practiced for revegetation of raw and spent shale piles and surface disturbances, seems adequate to complete the job as specified under current reclamation laws. Topsoiling, fertilization, mulching, irrigation, and plant species selection are all important for successful revegetation of spent shale and boiler ash piles. These issues are addressed in the reclamation plan. It is expected that boiler ash piles will require similar treatment in order to ensure successful revegetation. 


\section{RECOMMENDATIONS}

- Remove topsoil and stockpile before construction of spent shale and boiler ash piles. Topsoil should be removed just prior to dumping spent shale and ash materials to minimize topsoil storage time. Also, only small areas should be disturbed at any one time prior to the construction of the piles. As pile construction progresses, the topsoil removed for future piles should be placed on the completed pile immediately (leaving the initial stockpiled topsoil to cover the last area of the pile when completed) so as to maintain a viable microorganism population in the topsoil. This corresponds with the topsoil handling plan as proposed by Occidental.

- Twelve inches of suitable material are recommended to be placed on the spent shale or boiler ash piles for revegetation. Salts have been shown to move to the surface of soil replaced on piles less than 10 inches thick. Topsoil depths of 10 inches or less may not provide enough buffering for the salts moving up from the shale or ash. Twelve inches is recommended as the minimum level of soil coverage on spent shale piles. Topsoil is available on the site and at amounts necessary to meet this recommnedation. Irrigation appears to be necessary to establish a plant cover greater than 50 percent during the first growing season which is necessary to control erosion. Subsequent irrigation does not appear to be important unless a very dry growing season occurs.

- Fertilization at the rate of $50 \mathrm{lbs} / \mathrm{ac}$ of nitrogen and $100 \mathrm{lbs} / \mathrm{ac}$ of phosphorus is necessary for plant establishment and growth. Fertilization is an important part of the revegetation plan. Potassium should also be added.

- The addition of an organic material (i.e. sewage sludge) was very beneficial in the establishment and growth of forages in spent shale demonstration plots. While not necessary for revegetation, adding high amounts of sludge or other organic matter, if available, will greatly enhance revegetation efforts.

- A number of salt tolerant grasses, forbs, and shrubs have been found to successfully establish and grow from seed in seeding trials on spent shale, and topsoiled and mixed spent shale. While the Occidental seed mixture was proven successful for revegetation, my recommendation would be to reduce the number of grasses and forbs in the seed mix. However, inasmuch as seed costs are not a great expense in comparison to transportation of spent shale and ash to the pile and other pile construction costs, the seed mixture that has proven successful can remain.

- In the event that seed costs escalate dramatically, reduce the number of grasses seeded to four, the number of forbs seeded to three, and the number of shrubs seeded to three. Additional seed simply presents competition among plants for limited resources. Transplanting of shrubs and trees is unnecessary. 


\section{Selected References}

Bloch, M.B., and P.D. Kilburn. 1973. Processed shale revegetation studies, 1965-1973. Colony Development Operation, Atlantic Richfield Company, Denver, CO. 208 pp.

Cathedral Bluffs Shale Oil Company. Annual Reports. 1979-1988.

Cook, C.W. 1974. Surface rehabilitation of land disturbances resulting from oil shale development. Env. Res. Center, Colorado State University Info. Ser. No. 11. 55 pp.

Davis, G. 1978. Oil Shale. pp. 6()9-618. In: Schaller and Sutton (eds.), Reclamation of Drastically Disturbed Lands. American Soc. Agron., Madison, WI. 676 pp.

Frischknecht, N.C., and R.B. Ferguson. 1979. Revegetating processed oil shale and coal spoils on semiarid lands. USDI, EPA 600/7-79-068. Cincinnati, OH. $47 \mathrm{pp}$.

Occidental Oil Shale, Inc. 1985. Revised Detailed Development Plan. Grand Junction, CO. Redente, E.F., and C.W. Cook. 1982. Revegetation studies on oil shale related disturbances in Colorado. U.S. Dept. of Energy, Report No. DOE/EV/()4010. Colorado State University, Fort Collins, CO. 84 pp.

Schramm, L.W. 1975. Mineral facts and problems--shale oil. USDI, Bureau of Mines Bulletin 667. 26 pp. 


\section{APPENDIX VI}

\section{Topic Area: $\quad$ WILDLIFE}

2. Subtopic: $\quad$ N/A

3. Review Team Leader: James A. MacMahon

Dean, College of Science

Utah State University

Logan, Utah

\section{ABSTRACT}

A library and brief field study of the C-b Oil Shale Tract in the Piceance Basin of western Colorado was conducted. The site visit was conducted in April 1990. The extensive literature holdings of the library of the EMRx Corporation provided most of the documents used. In addition, the proposal for the Proof-of-Concept study was available and was evaluated.

The background documents that have been assembled by a variety of workers to evaluate the influences of oil shale development on wildlife provide an accurate representation of the status of wildlife and the prospects of the effects of development of the oil resource on a wide range of wildlife species, including both game and non-game species. Most of the baseline studies related to the C-b Tract were conducted between 1974 and 1980. Despite a ten year interval since the last detailed studies, there is no obvious reason to question their current validity. Given that this is the case, the analysis of wildlife present in Section 2.5 of the "Revised Detailed Developmcnt Plan $1985 "$ is considered to be an acceptable representation of the status of wildlife on the Tract.

The results of the current analysis suggest that the Proof-of-Concept study will have few, if any, negative impacts on the populations of wildlife species. In fact, the proposed study may be the only reasonable way to collect data to evaluate the actual impacts of the modified in-situ methodology for extracting oil from shale on wildlife. The proposed pilot study is sufficiently small in scale that if there are negative impacts, they will be minor. Data from this experience should allow us to scale-up to the potential impacts of commercial level oil production.

The proposal includes, as a mitigation measure, some habitat conversion and restoration that should offset the expected habitat loss caused by the Proof-of-Concept studies (Table 6.1.1, Revised Detailed Development Plan). This action should be sufficient for the purposes of this particular proposal.

\section{SUMMARY OF FINDINGS TO DATE}

Comments in this section are generally limited to terrestrial, vertebrate animals. There are too few data, past or present, to determine what might happen to invertebrates. It can be reasonably stated, however, that the vegetation types of the area surrounding the mine site are widespread across 
parts of Colorado, Wyoming and Utah. Invertebrate species in these communities are not expected to have limited distributions. In addition, most invertebrates that would be displaced by any of the proposed activities are highly mobile and can redistribute themselves easily. Aquatic organisms were not considered. The water produced during the MIS process will be recirculated or otherwise treated. No release of process water is planned and no negative influences are anticipated. The ravine immediately adjacent to the site has infrequent seasonal flow and does not support a normal aquatic fauna. Assuming that the water quality data are correct, down stream influences from subsurface flow should have minimal influences on the permanent waters that contain both fish and invertebrates.

R pt Is ad mA ph bian - Few species have been observed at the site. approximately ten species known from the general area (seven have been recorded in previous surveys and another three are certainly present but were probably missed because of survey techniques used) none are threatened or endangered. One snake (Thamnophis elegans) and two amphibians (Rana pipiens and Ambystoma tigrinum) are associated with mesic areas and are probably limited to areas away from the main mining operations. The more common forms are the lizards. There is little in the proposed mining process that should negatively influence their populations. If any change is noted it may be a very minor increase in population size or a redistribution of Sceloporus graciosus in response to the mining activities, providing more hiding sites among refuse piles scattered across the site.

Birds - About 136 species of birds have been recorded from the C-b Tract. Of these 39 are considered to be common. While there are a reasonable number of song birds known from the area, concern has been directed to the populations of upland game birds, raptors and waterfowl. The two upland gamebirds, the mourning dove and the sage grouse, are not common immediately adjacent to the plant. Sage grouse is represented by small populations in the general area of the site. Neither species is likely to be negatively influenced by increased activity around the site.

The raptor community is composed of 11 hawks and eagles, 8 owls and the common raven. None seem likely to be harmed by the proposed activities. Peregrine falcons are rarely reported from nearby areas. Suitabie nesting sites are sufficiently distant that increased mining activities are not expected to create problems if birds are present in the area. The golden eagle is a permanent resident of the area and the bald eagle is a winter resident. Neither should be influenced in a measurable way.

In general no negative effects on the avian community are anticipated.

Mammals - The data that are available for mammals varies in quality. Large bodies of "quantitative" data are available for small mammals. These data are probably not as good as was thought when they were collected. About 16 species of small mammals have been recorded from the site. None of the small mammals found in the area of the C-b Tract are likely to be negatively impacted by the proposed project. While some species are not common in the area, and they may be restricted to specific and areally limited habitats, their distributions are not confined to that portion of Colorado. This is of some importance because the boiler ash will be placed in a ravine that undoubtedly supports some mammals that will be displaced. Since this specific microhabitat is

$$
\mathrm{VI}-2
$$


limited close to the mine, suitable areas for reestablishment of the displaced individuals may not be available. The total number of animals lost, across all species, is likely to be less than 20 .

Estimates of the number of medium - sized mammals are probably not at all reliable. Survey techniques used in the past are not appropriate for obtaining such estimates. The entire cadre of these species is highly mobile and can easily move to other areas if they are disturbed by mining activities. In fact most of the species recorded, e.g., skunks, porcupines, coyotes, marmots and rabbits (actually a rabbit and a hare), adapt well to anthropogenic disturbance and at least the skunks may become more abundant.

Large mammals have been studied in great detail on the C-b Tract. The predators include bobcats and an occasional mountain lion. While a few elk are present the area, the major concern has always been the large mule deer herd. Large numbers of animals use the Tract and surrounding area for winter range. These are especially fond of nearby agricultural land and the chained rangeland, although they occur in nearly all habitats at some point during the year. Animals are strongly migratory and are essentially absent from the area from mid May to mid September.

While it is not likely that the proposed mining will influence the activities of the deer herd, it is quite likely that the number of road-killed animals will increase. Light conditions during the time of day that workers are going to and from the site, during the winter when the deer make maximum use of the site, will increase the probability that collisions with automobiles will occur. This will probably be a minor but measurable impact. Speed limits, special cautions and an educational program for workers may mitigate these effects. In addition the Revised Detailed Development Plan's Table 6.1.1 (1985) indicates that fences will be erected and project busing will be provided if necessary. Given the magnitude of the current project, I doubt that this will be necessary.

\section{IMPLICATIONS FOR OIL SHALE ENVIRONMENTAL POLICY}

There are no apparent, far reaching implications of the effects of this activity on wildlife for oil shale policy. An exception might be that during this experiment we may be able to increase our ability to scale-up our predictions about the effects, on wildlife, of production level development of the shale resource.

\section{KEY UNRESOLVED ISSUES}

There is no obvious issue that needs to be addressed that has not been addressed. Endangered species have not been identified on the site, to date. The small scale of the project probably precludes major wildlife impacts at this time. 


\section{RECOMMENDATIONS}

Purely from the perspective of the impacts on wildlife of the Proof-of-Concept experiment, I see no reason that the project should be delayed. Most mitigating activities that may be necessary either to protect affected species or to offset habitat loss are included in the proposal. 


\title{
APPENDIX VII
}

\section{Topic Area: $\quad$ ENVIRONMENTAL ANALYSIS}

2. Subtopic Area: Socioeconomic Assessment

\author{
3. Review Team Leader: Dennis A. Stranger \\ Glenwood Springs, $\mathrm{CO}$
}

\section{ABSTRACT}

The Proof-of-Concept Oil Shale Project, to be located on the federal oil shale lease Tract C-b in western Colorado, will be constructed and operated over a ten year period. The socioeconomic effects of the project are positive.

The development of the project will result in increased employment, personal income and public tax flows. Revenues will flow to local government jurisdictions, the State of Colorado and the federal government. Direct public revenues alone will amount to approximately $\$ 20$ million for state and local governments. $\$ 141$ million will be paid to project workers directly in the form of payroll wages with estimated indirect wages amounting to $\$ 169$ million for the ten year life of the project.

The project-related population represents only slightly over one percent of the population of the region and can be easily accommodated by existing towns and cities in the area. No adverse public impacts have been identified to date. The construction and operation of the project presents an opportunity to develop technical expertise in oil shale mining and processing with minimal socioeconomic impacts. It is anticipated that socioeconomic information collected during the Proofof-Concept project will facilitate permit acquisition and socioeconomic impact mitigation for commercial oil shale development projects.

The data sources for this review included socioeconomic and environmental monitoring reports from previous development on the C-b Tract, the 1985 Detailed Development Plan for the $\mathrm{C}-\mathrm{b}$ Tract and a recent study of public financial impacts prepared by the State of Colorado Department of Local Affairs. Some discussions were held with local government officials to verify information.

Data Sources: Archived documents and Colorado Department of Local Affairs. 


\section{SUMMARY OF FINDINGS TO DATE}

\section{Study Area}

The study area that has been defined by the project proponents encompasses Rio Blanco, Garfield, Mesa, Moffat and Routt counties in western Colorado. The socioeconomic effects of the project may also extend into a portion of eastern Utah (in the Vernal area). It is anticipated that most of the impacts will be in Rio Blanco, Garfield and Mesa counties. There are other industrial and construction projects in the study area including Unocal Corporation's Parachute Creek Shale Oil Program, construction of Interstate 70 in Glenwood Canyon and the federal Uranium Mill Tailings Remedial Action Program.

\section{Project Description}

Occidental Oil Shale, Inc. (OOSI) proposes to develop a "Proof-of-Concept" oil shale project on the Federal (oil shale) Tract C-b in Rio Blanco County, Colorado. The project site is located about forty miles northwest of Rifle, Colorado and approximately the same distance southwest of Meeker, Colorado. The project will entail construction and operation of in-situ (and possibly, above ground) oil shale retorts, an on-site power plant, an oil shale mine and related ancillary facilities. The project will require approximately three years to construct followed by a five to seven year operational program. The Proof-of-Concept project may lead to a commercial oil shale development program at the site.

The project will directly employ approximately 546 construction workers in the peak year of construction activity and about 285 operation workers in the peak year of operations. Total direct employment will range from 59 to 690 over the life of the project with an average direct employment of 268 workers. As described below, the peak employment year is Year 3 of the project.

\section{Projected Employment and Population}

Table 1 indicates the direct and indirect project employment by project year. Once the direct and indirect employment is determined, the population resulting from the development of the project may be projected. The employwent and population impacts were estimated by the Colorado Department of Local Affairs based on regional multipliers developed by the U.S. Department of Commerce. Table 2 shows the incremental project-related population residing within the five county study area. $\$ 141$ million will be paid to project workers directly in the form of payroll wages with estimated indirect wages amounting to $\$ 169$ million for the ten year life of the project. 
Appendix VII - Socioeconomic Assessment

Table 1. Project-Related Employment

\begin{tabular}{|c|c|c|c|c|c|c|c|c|c|c|c|}
\hline Project Year & 0 & 1 & 2 & 3 & 4 & 5 & 6 & 7 & 8 & 9 & 10 \\
\hline \multicolumn{12}{|l|}{ Direct } \\
\hline $\begin{array}{l}\text { Construction } \\
\text { Operation }\end{array}$ & $\begin{array}{r}54 \\
5\end{array}$ & $\begin{array}{r}189 \\
7\end{array}$ & $\begin{array}{r}364 \\
42\end{array}$ & $\begin{array}{l}546 \\
144\end{array}$ & $\begin{array}{r}61 \\
285\end{array}$ & 282 & 236 & 221 & 219 & 190 & 163 \\
\hline Total Direct & 59 & 196 & 406 & 690 & 346 & 282 & 236 & 221 & 219 & 190 & 163 \\
\hline Indirect & 35 & 117 & 202 & 441 & 402 & 366 & 296 & 273 & 271 & 295 & 320 \\
\hline
\end{tabular}

Table 2. Project-Related Population

\begin{tabular}{llllllllllll} 
Project Year & 0 & 1 & 2 & 3 & 4 & 5 & 6 & 7 & 8 & 9 & 10 \\
\hline $\begin{array}{l}\text { Popu- } \\
\text { lation }\end{array}$ & 162 & 532 & 1,036 & 2,064 & 1,669 & 1,500 & 1,232 & 1,141 & 1,136 & 1,125 & 1,121 \\
\hline Source: & $\begin{array}{l}\text { State of Colorado, Department of Local Affairs - Public Finance Impacts of the Proposed C-b Oil Shale Tract } \\
\text { Note: }\end{array}$ & $\begin{array}{l}\text { Reactivation: A Preliminary Assessment. } \\
\text { The DLA assumed that 40\% of the construction workforce and } 4 \% \text { of the operations workforce will commute to the } \\
\text { project site from outside ofthe five county study area. }\end{array}$
\end{tabular}

Several major anergy development projects were developed in the study area in the late 1970)s and early 1980s. Gärfield and Rio Blanco alone had several oil shale projects developing simultaneously (including development of the $\mathrm{C}-\mathrm{b}$ Tract). As a result of this cumulative impact, most of the local government entities expanded and upgraded their infrastructure and service capabilities to accommodate a larger population than currently resides in the study area. Many of the projects were curtailed resulting in reduced employment and attendant population in the region. Although the exact year of peak population varied from county to county, the 1983 population estimate represents the peak of the population residing in the area. Table 3 displays the estimated and projected populations for counties in the study area. 
Appendix VII - Socioeconomic Assessment

Table 3. Regional Population Estimates and Projections, Select Years

Year

1980

1983

1990)

1995

County

Rio Blanco

6,51

7,198

5,481

5,424

Garfield

22,972

28,538

27,465

30,491

Mesa

82,662

97,072

91,235

98,635

Routt

13,348

14,136

15,205

16,901

Moffat

13,205

15,126

11,030

11,477

Total

138,538

162,070

150,416

162,928

Source: Colorado State Demographer

\section{Population Distribution, Housing and Schools}

The State Demographer has projected a 1995 population of 162,928 for the study area. The project related population peak would occur in Project Year 3. The Colorado Department of Local Affairs pointed out in its assessment of the project that the development of the C-b Tract may coincide with the completion of the UMTRA program noted above and completion of major components of the Interstate 70 construction project in Glenwood Canyon. If this is so and if the workers' skills are transferrable to the OOSI project, then the region can very easily accommodate the proposed development. There are currently surpluses of housing and infrastructure capacity in many of the towns in the region.

It is anticipated that most of the construction and operation workers will reside in the study area and particularly in the Interstate 70 corridor between Glenwood Springs and Grand Junction as well as in the Meeker and Rangely areas in Rio Blanco County. The access to the C-b Tract from the various towns and cities has been improved since 1981 when the development of the C-b Tract was actively being pursued. Access improvements include the completion of Interstate 70 through Debeque Canyon providing improved access to the Grand Junction area and the completion of the Rifle bypass which permits traffic from Interstate 70 to avoid the City of Rifle for a faster, more direct route to the $\mathrm{C}-\mathrm{b}$ Tract.

A significant amount of housing for workers on the C-b Tract was located in Rifle during the previous development cycle (52\% in 1981). Rifle currently does not have any housing available and has a major infrastructure constraint associated with the City water system. In addition, Glenwood Springs and New Castle do not have any vacant housing and other towns in Garfield County have

$$
\text { VII - } 4
$$




\section{Appendix VII - Sociocconomic Assessment}

limited available housing with the exception of Parachute and Battlement Mesa. Battlement Mesa, however, is a large new development offering housing alternatives that did not exist during the initial development of the C-b Tract. The availability of housing in Battlement Mesa and in the Town of Parachute combined with the improved access from the west via the Rifle bypass should provide adequate housing for the Proof-of-Concept project. Meeker and Rangely in Rio Blanco Cour $y$ have existing capacity to accommodate approximately 1,000 more people than currently reside in those two towns. Schools in the region have moderate capabilities to accept new growth.

Except for the Rifle water system, there are no major infrastructure deficiencies in the towns and cities in the study area. Schools in the region have moderate capabilities to accept new growth. The forecast distribution of the Tract C-b related population is indicated in Table 4.

Table 4. Distribution of Project-Related Population

\begin{tabular}{|c|c|c|c|c|c|c|c|c|c|c|c|}
\hline Project Year & 0 & 1 & 2 & 3 & 4 & 5 & 6 & 7 & 8 & 9 & 10 \\
\hline \multicolumn{12}{|l|}{ Community } \\
\hline Meeker & 7 & 20 & 41 & 138 & 232 & 226 & 185 & 172 & 171 & 169 & 16 \\
\hline Rifle & 8 & 21 & 41 & 142 & 242 & 235 & 193 & 179 & 178 & 176 & 17 \\
\hline Silt & 4 & $i 1$ & 21 & 76 & 134 & 131 & 108 & 100 & 99 & 98 & \\
\hline Parachute & 7 & 19 & 38 & 109 & 157 & 151 & 124 & 115 & 114 & 113 & 113 \\
\hline New Castle & 3 & 10 & 19 & 53 & 75 & 72 & 59 & 54 & 54 & 54 & \\
\hline Rangely & 9 & 28 & 54 & 126 & 142 & 133 & 10.3 & 101 & 101 & 100 & \\
\hline \multicolumn{12}{|l|}{ Glenwood } \\
\hline Springs & 26 & 87 & 169 & 304 & 177 & 149 & 122 & 113 & 113 & 112 & \\
\hline Debeque & 0 & 0 & 0 & 0 & 0 & 0 & 0 & 0 & 0 & 0 & \\
\hline Craig & 14 & 44 & 87 & 174 & 144 & 130 & 106 & 99 & 98 & 97 & \\
\hline Palisade & 5 & 17 & 34 & 62 & 37 & 32 & 26 & 24 & 24 & 24 & \\
\hline Hayden & 3 & 9 & 17 & 31 & 18 & 15 & 13 & 12 & 12 & 12 & \\
\hline $\begin{array}{l}\text { Grand Junction } \\
\text { Steamboat }\end{array}$ & 62 & 215 & 415 & 684 & 249 & 180 & 148 & 137 & 136 & 135 & \\
\hline Springs & 15 & 52 & 100 & 166 & 63 & 47 & 39 & 36 & 36 & 35 & \\
\hline TOTAL & 162 & 532 & 1,036 & 2,064 & 1,669 & 1,500 & 1,232 & 1,141 & 1,136 & 1,125 & 1,1 \\
\hline
\end{tabular}

Source: State of Colorado. Department of Local Affairs-Public Finance Impacts of the Proposed C-b Oil Shale Tract Reactivation: A Preliminary Assessment.

\section{Project-Related Public Revenues and Expenditures}

Revenues from the project will accrue directly to the state and local government jurisdictions. Indirect revenues such as individual income taxes will also be generated and will be paid to the federal anu state governments. 
Local government revenues will come primarily from property, sales and use taxes which combined, will total approximately $\$ 10.3$ million in local government revenues (Colorado Department of Local Affairs). Property tax revenues are estimated to total $\$ 8.2$ million over the ten project years based on current mill levies and assessment procedures. Local sales and use tax revenues from the project will amount to about $\$ 2.1$ million. The local taxes will accrue primarily to Rio Blanco County and the Meeker School District.

The State of Colorado will receive project-related revenues from a variety of sources which will total approximately $\$ 9.8$ million (Colorado Department of Local Affairs). State sales taxes from the project will be about $\$ 3.2$ million. It is estimated that royalty payments from the C-b Tract Federal Mineral Lease will generate $\$ 6.0$ million dollars for the state. The C-b lease is presently suspended and is being renegotiated which may effect the lease revenue estimates. Other direct state revenues are corporate income taxes and mineral severance taxes.

No state or local government expenditures for services in support of the project have been identified. The short duration of the construction period and the general availability of housing, schools and local government facilities within the study area indicate that the region can accommodate the project workforce and related population. This is so as long as the project-related population resides in communities with sufficient infrastructure capacity to accept growth without the necessity to expand capital facilities.

It is not known at this time if government staff resources exist at the various local government jurisdictions to provide adequate services although it is apparent that the total impact from the project will not significantly increase the population in the study area. The local government jurisdictions in the area substantially reduced personnel after the curtailment of large energy development projects in 1981 and 1982 and most have been operating at reduced staff levels since. The small project workforce and modest development cycle of the project should alleviate the need for locial governments to increase staff levels to deal with the increase in population.

Indirect revenues will be generated by the project- elated population residing in the various towns and cities and counties in the area. Such indirect revenues include property taxes and sales taxes paid by individuals. It is assumed that the local government budget structures and revenue streams can accommodate population growth and increased service demands so long as major capital expenditures are not required.

\section{Impact Assessment}

The effects of the project on the economic base of the area will be increased employment, income and tax flows. In addition, the construction of new housing for workers and their families moving into the area will provide a one-time stimulus. 
The fiscal impacts are generally positive with approximately $\$ 20$ million accruing to the State of Colorado and local governments directly from property, sales, use and other tax sources. The local government revenues will flow to Rio Blanco County, the Meeker School District and some other jurisdictions in Rio Blanco County resulting in a slight jurisdictional mismatch of revenues to possible expenditures by local government jurisdictions not receiving direct revenues.

The peak project related population of 2,064 represents an increase of only one percent over the current population estimate of the study area. The population can easily be accommodated by communities in the area although it should be noted that some communities do not presently have surpluses of housing. The distribution of the workforce residences is facilitated by improved transportation linkages to the site. The construction of new housing appears to be within the capabilities of the housing industry in the area.

The only public service capacity threshold that has been reached is the water system in the City of Rifle. Further population growth in Rifle will require upgrading of the water system.

Housing is available in Meeker and Rangely in Rio Blanco County, Parachute/Battlement Mesa in Garfield County, and Debeque, Palisade and Grand Junction in Mesa County. The brief duration of the construction employment peak will present opportunities to provide short term temporary housing if required. The study area currently has an excess of housing (an estimated total excess population capacity of 6,200 per the State of Colorado).

The public fiscal effects of the project appear to be positive as long as no major capital expenditures are required. School systems in the study area have the capability of absorbing the growth associated with the development of the Proof-of-Concept project. The Meeker school district will accrue about $\$ 5.4$ million from the project's property taxes. The State of Colorado will also receive substantial revenues from the project in the form of sales and use taxes, mineral severance taxes and federal lease payments.

The effects of development of a commercial oil shale project at the C-b Tract were not considered in this review. It may be inferred that a full scale commercial project would have different socioeconomic effects than the Proof-of-Concept project-many positive and some negative.

\section{IMPLICATIONS FOR OIL SHALE ENVIRONMENTAL POLICY}

The Proof-of-Concept project presents an opportunity to develop technical capabilities with minimum socioeconomic impacts. The rational development schedule meshes favorably with projected downturns in other construction projects in the area. The implication is that, properly planned, projects could be developed sequentially without creating massive cumulative impacts of simultaneous development such as took place in the previous oil shale development cycle. The results could be less volatility in local labor markets and more stability in the local economy. 
The caveat to the above statement is that the Proof-of-Concept project is not a commercial scale operation. It is assumed that the eventual commercial development of the site may, however proceed with the same deliberate, measured pace resulting in minimum socioeconomic impacts. The most important effect of a larger scale operation is a possible jurisdictional mismatch among local governments where revenues accrue to one jurisdiction and impacts occur in another. This potential situation should be acknowledged and monitored during the Proof-of-Concept stage. The knowledge gained during the project will help guide possible future socioeconomi; mitigation efforts.

\section{KEY UNRESOLVED ISSUES}

There do not appear to be any significant unresolved socioeconomic issues associated with the Proof-of-Concept project. It is not known if specific socioeconomic assessment requirements for Rio Blanco County and federal permits have been satisfied at this time.

\section{RECOMMENDATIONS}

It is recommended thist the project sponsor undertake socioeconomic monitoring for the duration of the project. The workforce characteristics, skill levels, trades, etc. should be noted in order to ascertain the transferability of workers to and from the C-b project. The residency patterns should be documented. This information will expedite subsequent commercial development at the $\mathrm{C}$-b Tract since more attention will be directed towards socioeconomic impact mitigation for commercial scale projects. 


\section{APPENDIX VIII}

\section{Topic Area: $\quad$ ELECTRICAL TRANSMISSION}

2. Subtopic: N/A

3. Review Team Leader: F. J. Calzonetti

Assistant Dean for Research and Graduate Studies

College of Arts and Sciences

West Virginia University

\section{ABSTRACT}

This section provides an evaluation of the issues and implications relating to electricity transmission that may arise with the reactivation of Occidental Oil Shale, Inc. Modified In-situ (MIS) plant at the C-b site near Meeker, Colorado. Since the sale of power is essential for the economic success of the project, electricity transmission is an important area of concern. The siting of electricity transmission lines has grown into a contentious issue over the past twenty years as demonstrated by the many projects halted or delayed throughout the country over siting disputes. Problems in siting transmission lines is exacerbated by uncertainties and conflicting studies regarding the impacts of electromagnetic fields on human health. Thus, it is wise to anticipate any problems relating to electricity transmission. At the C-b site, the transmission facilities are already in place which will allow Occidental Oil Shale, Inc. to export the power to be generated by its circulating fluidized bed combustor.

At the present time, no new transmission facilities are required to reactivate the MIS plant at the C-b site. Also, after examination of supporting documents and following site reviews and interviews with Occidental personnel, there does not appear to be any serious environmental, health, or safety concerns relating to electricity transmission resulting from the reactivation activity, the construction of the circulating fluidized bed cornbustor, nor the cogeneration and sale of power. It should be noted that the topic of electricity transmission will be one of the five areas to be addressed in the Environmental Impact Statement requested by the Bureau of Land Management.

\section{SUMMARY OF FINDINGS TO DATE}

\section{a. Proof-of-Concept Electricity and Transmission Requirements}

The proof-of-concept oil shale facility at Colorado Tract $C$-b will involve the construction of a circulating fluidized bed combustor (CFBC). The facility is designed to generate some 45 
MW of (cogenerated) power of which about $33 \mathrm{MW}$ will be available for sale to a regional utility. The power plant will generate revenues for the project and help the viability of the project. Also, the power plant provides the necessary means of burning and cleaning the gases from the MIS process and uses the natural sulfur removal properties of oil shale (when combusted in the power plant). Revenues are projected to be $\$ 13.7$ million annually according to the June 1990 Demonstration Project Assessment Report. According to Occidental personnel, if the project goes to $22,000 \mathrm{bbls}$./day production (from 1,206 bbls./day), then a total of $70 \mathrm{MW}$ will be required to serve the C-b facility. It is expected that $120 \mathrm{MW}$ of CFBC capacity would then be installed on site, allowing $50 \mathrm{MW}$ of capacity to be sold. This will accommodate even optimistic development scenarios at the C-b site through the year 2010. An existing 138-kv transmission line is now used to purchase power but the same line will be used to sell power once the CFBC plant is in operation. Thus, there should be absolutely no need to construct additional transmission capacity to service up to 22,000$)$ bbls./day production. If production increases to $50,000 \mathrm{bbls}$./day, or if independent markets are sought for the power plants constructed at the site, then additional transmission facilities may be required.

\section{b. Electricity Transmission}

Electricity is currently supplied to the C-b site by White River Electric Association of Meeker, Colorado via a 20 mile long $138-k v$ power line. Most of this right-of-way is over public lands acquired through special land use permits issued by the U.S. Bureau of Land Management. The line enters the C-b site at a 138-kv switchyard owned by White River Electric Association. This switchyard will accommodate a second source of power to be connected to the site, and minor modifications of the switchyard will be required. It was anticipated in the 1985 Revised Development Plan that in the event of full-scale comercial development, a second line would follow the existing right-of-way. In this event, the present right-of-way would be evaluated for its potential to include an additional transmission line. This additional transmission capacity would only be required by a significant expansion at the C-b site (e.g. to 50,000 bbls./day capacity).

The proof-of-concept operation will not require the construction of new transmission capacity, only minor modifications of existing switchyards (both at the C-b site and at Meeker). The existing 138-kv line will be used to sell cogenerated power. The environmental, health and safety impacts possibly arising from the 138-kv transmission line are discussed in the February 19, 1980 Environmental Assessment, and the topic will be considered in a new Environmental Impact Statement. The 1980 report shows that the existing $138-\mathrm{kv}$ line was constructed according to standards described in Electric Transmission Specification and Drawings, REA Form 805 (Rev 2-73) and by the sixth edition of the National Electric Safety Code. Also, since the line would be crossing an area with a raptor population, the pole structures were designed according to REA Bulletin 61-10 (March 9,1979) Powerline contacts by eagles and other large Birds to minimize impact of the line to raptors. 


\section{c. Impacts of the Transmission Line}

The impacts of any electricity transmission line are related to the voltage of the line and the sensitivity of the environment through which the line passes. Extra-high voltage lines at 500$\mathrm{kv}$ and $765-\mathrm{kv}$ have been sited in heavily populated regions in the eastern United States, but plans to construct similar facilities have met with opposition. The impacts of the 138-kv line are proportionally less than the impacts expected from a $500-\mathrm{kv}$ or $765-\mathrm{kv}$ line because of the reduced electromagnetic field effects, the lower height of the structures and the narrower right-ofway required. In fact, most utility planners do not consider 138-kv lines as extra high voltage lines.

The environmental, health and safety impacts of the 138-kv transmission line was assessed in the February 1980 Environmental Assessment. Although additional study would be required to expand transmission capacity to serve the C-b site, the report does summarize the important considerations which would need to be evaluated. The existing and new line will have minimal impacts to air quality, water availability and quality, vegetation, soils, cultural features, human populations, recreational resources, or wildlife. Concern for raptors is important given the population of them in the area. An appendix to the environmental assessment prepared by Professor Clayton White (Analysis of Raptors) indicated that the $138-\mathrm{kv}$ line would not pose a significant negative impact to raptors or other birds. Bald and golden eagles which hunt in the area tend to use transmission line structures for hunting perches, and other species such as ferruginous hawks, red-tailed hawks, and ravens use poles for nests. Whether used for nests or hunting perches, the design of the line and structures eliminates electrocution possibility and the birds' activities will have little effect on the operation of the line.

The impact of the line on the aesthetic value of the area can not be avoided, and the rightof-way was selected partially in order to minimize aesthetic degradation. The maximum visual disturbance is where the line crosses the Piceance Creek Valley because markers are placed on the conductors to warn pilots in low flying aircraft.

Electromagnetic field effects of transmission lines have been discussed as leading to human health impacts, and this is a serious siting problem in heavily populated places in the east. However, given the size of the line and the sparsely settled environment, this impact should be minimal or nonexistent.

There was uncertainty because OOSI until recently did not have a buyer for the power, even though the CFBC is connected to the giid. Options under investigation included purchasing an existing Power Purchase Agreement and transferring it to the project; entering into a joint venture with a current Power Purchase Agreement contract holder; and/or directly negotiating with utilities or other customers. However, OOSI now has in place an option to buy an existing Power Purchase Agreement and the company will continue to explore other options. Given that the greatest demand for power in the region is in the Colorado Front Range, the use of Public 
Service Company of Colorado transmission facilities will probably be required. Although transmission availability should not be difficult for the small quantity to the marketed, it is important for this issue to be resolved because the revenues from power sales are so important for the economic success of the project.

\section{IMPLICATIONS FOR OIL SHALE ENVIRONMENTAL POLICY}

The existing 138-kv line and switchyard has minimal environmental, health and safety impacts to the area. Plans to build the circulating fluidized bed combustion power plant will not require the construction of additional transmission lines which is usually the case when new power plants are built. Instead of purchasing power from White River Electric Association, Occidental will use the existing 138-kv line to sell power. It is possible that OOSI may buy power from time to time under a buy-sell arrangement with White River Electric Association, particularly during years prior to startup, during peak loads, and during power plant shutdowns. Therefore, no transmission line impacts are expected from the reactivation of the $\mathrm{C}-\mathrm{b}$ site.

Even if it is necessary in the future to construct new transmission lines, including those rated at 500-kv, there should not be any outstanding environmental, health, and safety problems that can not be addressed through prudent construction and design procedures and a careful selection of the right-of-way to avoid sensitive locations.

\section{KEY UNRESOLVED ISSUES}

If the capacity of the C-b site grows to the $50,000 \mathrm{bbl} . / \mathrm{av}$ level, it will be necessary to consider expanding transmission connections to the site. Increased demand at the site, and the need to prepare for outages at the power plant and contingencies with the line will require alternative sources of electricity supply other than the existing 138-kv line. If the sale of power is necessary for the oil shale facility to be profitable, then markets for power will be sought. Depending upon the location of the markets with regard to the existing transmission configuration and wheeling arrangements, it is possible that consideration will be given to the construction of new lines.

\section{RECOMMENDATIONS}

There do not appear to be any electricity transmission impacts associated with reactivation of the Occidental Oil Shale, Inc. Modified in-situ (MIS) plant at the C-b site near Meeker, Colorado. As plans to expand the facility progress beyond that now under consideration, and if new markets for power arise, then there may be a need for new transmission capacity, which of course will require careful consideration of this topic. 

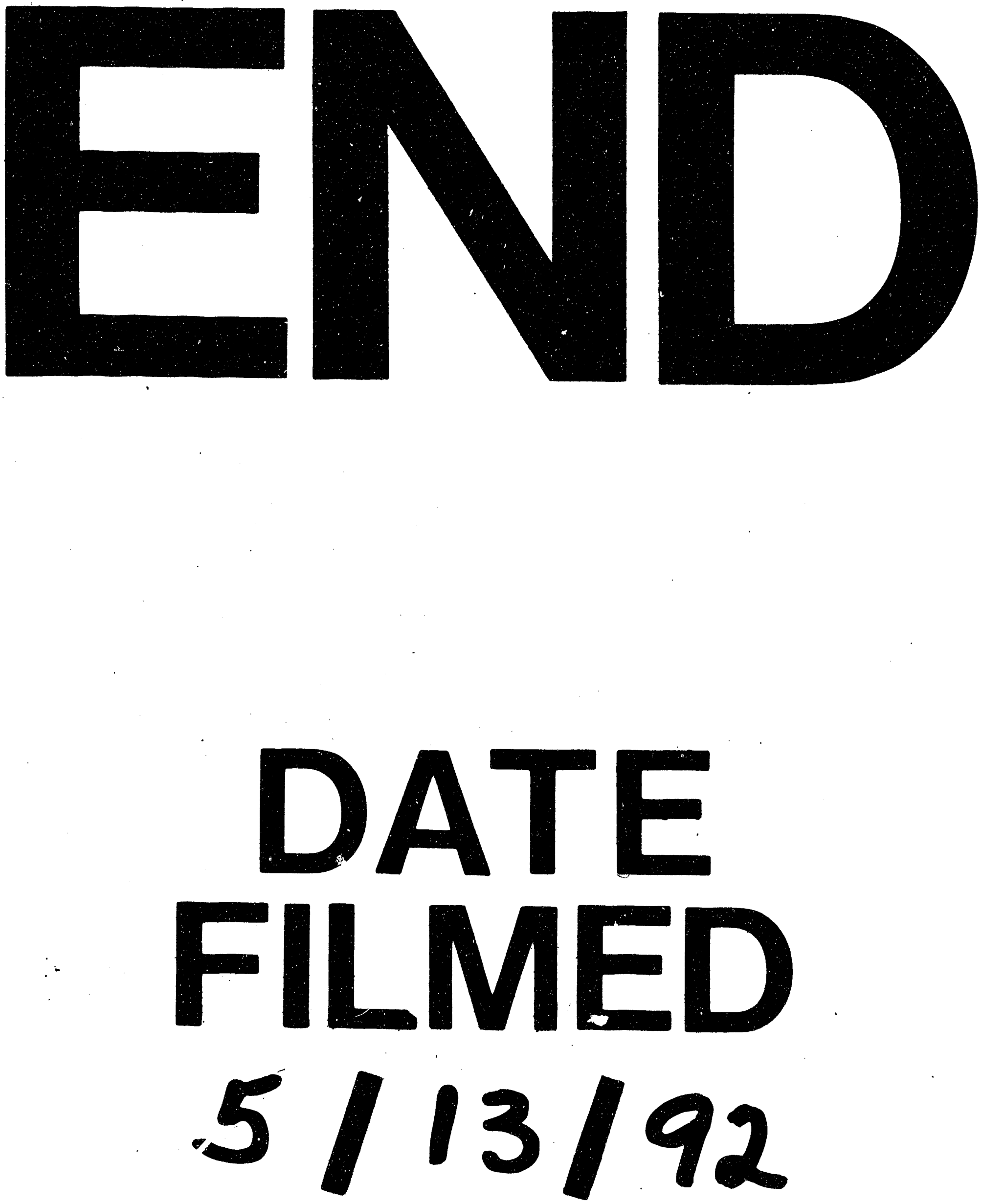
